UNIVERSIDADE DE SÃO PAULO

FACULDADE DE FILOSOFIA, LETRAS E CIÊNCIAS HUMANAS DEPARTAMENTO DE ANTROPOLOGIA

PROGRAMA DE PÓS-GRADUAÇÃO EM ANTROPOLOGIA SOCIAL

MARIA ISABEL ZANZOTTI DE OLIVEIRA

NAS MARGENS DO CORPO, DA CIDADE E DO ESTADO:

Educação, saúde e violência contra travestis

v.1

São Paulo

2015 
UNIVERSIDADE DE SÃO PAULO

FACULDADE DE FILOSOFIA, LETRAS E CIÊNCIAS HUMANAS DEPARTAMENTO DE ANTROPOLOGIA

PROGRAMA DE PÓS GRADUAÇÃO EM ANTROPOLOGIA SOCIAL

\title{
NAS MARGENS DO CORPO, DA CIDADE E DO ESTADO: Educação, saúde e violência contra travestis
}

\author{
Maria Isabel Zanzotti de Oliveira
}

Dissertação apresentada ao Programa de Pós Graduação em Antropologia Social do Departamento de Antropologia da Faculdade de Filosofia, Letras e Ciências Humanas da Universidade de São Paulo para a obtenção do título de Mestre em Antropologia, sob orientação da Prof. ${ }^{a}$ Dr. ${ }^{a}$ Laura Moutinho

v.1

São Paulo

2015 


\section{Agradecimentos}

Agradeço, imensamente, à Denise Martins e Bethânia Santos, da Associação Mulheres Guerreiras, pela maravilhosa recepção em sua comunidade que permitiu a realização desta pesquisa.

À minha parceria de estudos e incursões etnográficas, Letizia Patriarca, sendo seu apoio fundamental na minha entrada em campo e na construção deste trabalho. Também sou muita grata por sua amizade, hospitalidade e companheirismo.

Sou muito grata a Laura Moutinho, minha orientadora, pela presença, dedicação e paciência ao me auxiliar na elaboração desta dissertação.

À CAPES (Coordenação de Aperfeiçoamento de Pessoal de Nível Superior) e ao PPGAS pela bolsa de mestrado concedida em dezembro para a fase final de escrita da dissertação.

Aos funcionários da secretária de Pós-Graduação do PPGAS/FFLCH da USP.

À Secretaria Estadual de Educação do Estado de São Paulo pelo afastamento para cursar Pós-Graduação que permitiu a conclusão desta pesquisa.

Às companheiras do amado "Brilho", grupo de leitura que participo junto de Silvana Nascimento, Letizia, Luiza Ferreira e Pamela Villanova, pelo acolhimento e partilha de bibliografias, ideias e inquietações.

Ao meu amigo e companheiro Leonardo Lessa pelas inúmeras vezes que leu e me ajudou a revisar este e outros trabalhos me oferecendo insights importantes para este texto.

Ao amigo Pedro Lopes pelo suporte na revisão e formatação desta dissertação.

Aos companheiros de trabalho e alunos da Escola Estadual Dom José de Camargo Barros pelo apoio e acolhimento desta minha função de professora que também é pesquisadora.

Ao meu pai pela dedicação e respeito ao meu trabalho que possibilitou, dentre outras coisas, as caronas todas as vezes que foram necessárias minhas idas ao Itatinga. E a minha mãe pelo incentivo, paciência e toda sorte de suportes que somente as mães podem oferecer. 


\section{RESUMO}

Esta pesquisa visa descrever como determinadas demandas por cidadania são construídas e reivindicadas por travestis e transexuais, tendo como base a etnografia de uma residência coletiva localizada numa região da cidade de Campinas /SP na qual a principal atividade econômica é o comércio sexual. Portanto, este trabalho tem como finalidade compreender como estas pessoas vivem e fazem a política a partir das margens, visto que estas mulheres trans representam as fronteiras do corpo e da cidadania residindo em uma localidade que também é uma fronteira física, social e simbólica. Deste modo, observamos ao longo desta dissertação os grupos sociais que compõem esta vizinhança, incluindo as travestis e transexuais, que, apesar de em determinados contextos estarem situados às margens da Cidade e do Estado, também fazem parte de um conjunto de circuitos políticos, religiosos e econômicos externos a esta região. Assim, esta pesquisa descreve as redes que conectam esta localidade, as pessoas trans e o movimento de prostitutas locais, ao circuito político composto por movimentos sociais, pesquisadores, artistas, ONGs, partidos políticos, políticos profissionais e, por fim, aos agentes do Estado na construção e articulação de demandas que são específicas das mulheres trans, especialmente as relativas a saúde, educação e combate à violência.

\section{PALAVRAS-CHAVE}

Travestis, transexuais, transcidadania, movimentos sociais, prostituição. 


\begin{abstract}
This research aims to describe how certain demands for citizenship are constructed and enforced by travestis and transsexuals, starting from the ethnography of a collective residence located in a region in the city of Campinas/SP which the main economic activity is the sex trade. Therefore, this work has the purpose understand how this people lives and makes the political from the margins, since these women trans represent the boundaries of the body and of citizenship residing in a location that is also a frontier physical, social and symbolic. In this way, we observed throughout this dissertation the social groups that build this neighborhood, including the transvestites and transsexuals, although in certain contexts they are situated on the margins of the City and of the State are also part of a set of circuits political, religious and economic external to this region. Thus, this study describes the networks that connect this region, people trans and the movement of local prostitutes, to political circuit composed of social movements, researchers, artists, NGOs, political parties, professional politicians and, finally, to the agents of the State in the construction and articulation of demands that are specific to women trans, especially those relating to health, education and the fight against violence.
\end{abstract}

\title{
KEYWORDS
}

Travestis, transexual, transcitizien, social-movements, prostitution. 


\section{Sumário}

INTRODUÇÃO. $O$ "inglês" como dádiva: a construção de nossa entrada em campo 1 CAPÍTULO 1. O Itatinga: A segregação e a criação de um "parque temático"....... 15

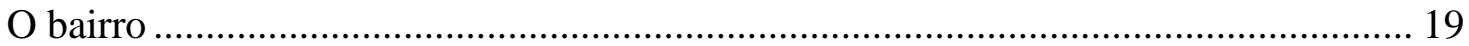

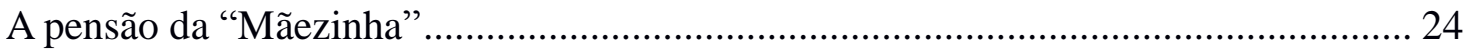

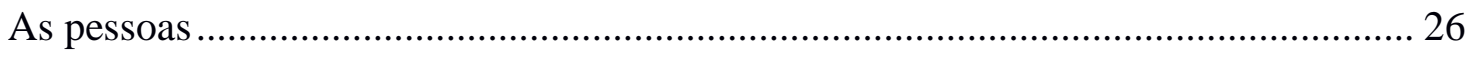

O CEPROOM e a Associação .............................................................................. 31

a) "Isabelzinha, agora você já está entendendo melhor o que é prostituição" ........ 35

b) Qual o lugar da prostituição no feminismo? ....................................................... 37

CAPÍTULO 2. Como se faz e se vive a política desde das margens ............................ 44

Redes, trajetos e circuitos. Do Itatinga para outros lugares ............................................ 44

As margens do corpo, da cidade e do Estado................................................................ 50

As margens e a violência .......................................................................................... 54

Entre a Casa e o Estado: saúde, bem-estar e beleza..................................................... 68

CAPÍTULO 3. A educação para uma transcidadania ................................................. 76

A Mãezinha como educadora................................................................................... 76

As educadoras militantes ...................................................................................... 81

Quem pode trans(itar) pela Escola? Narrando experiências escolares de trans-formação

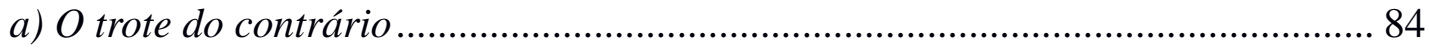

b) A performance, o confronto e a violência ............................................................. 86

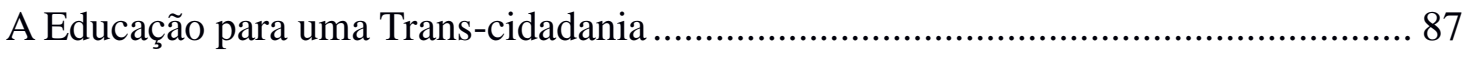

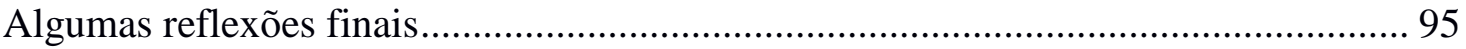

CAPÍULO 4. Classificações trans: "como se diz 'travecão' em inglês"? ................... 101

Entre Trans, Travestis e Transexuais...........................................................................110

CONCLUSÃO. A política das "Locas" e a política das trocas...................................119

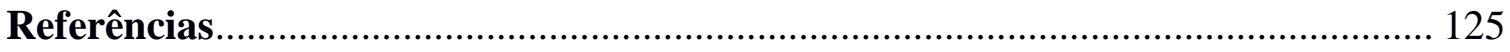




\section{INTRODUÇÃO. O "inglês" como dádiva: a construção de nossa entrada em campo}

Esta pesquisa visa analisar como certas demandas por cidadania são construídas e reivindicadas por travestis ${ }^{1} \mathrm{e}$ transexuais, tendo como recorte etnográfico a observação de uma residência coletiva de mulheres trans localizada no Jardim Itatinga, bairro da periferia da cidade de Campinas, que tem a prostituição como principal atividade econômica.

Estas mulheres trans representam as fronteiras do corpo e da cidadania e o bairro se caracteriza como uma fronteira, que sendo física, também é social e simbólica. Os grupos sociais que o compõem, incluindo as travestis e transexuais, ao mesmo tempo que em certos contextos estão situados às margens da cidade e do Estado, conectam-se ao conjunto de circuitos políticos, religiosos e econômicos externos ao Itatinga, que são constitutivos desta localidade. Deste modo, este trabalho visa descrever e compreender as redes que conectam o bairro, as pessoas trans e o movimento de prostitutas locais ao circuito político composto por movimentos sociais, pesquisadores, artistas, ONGs, partidos políticos, políticos profissionais e, por fim, os agentes do Estado, na construção e articulação de demandas que são específicas das mulheres trans.

Assim, no decorrer do trabalho de campo verificou-se que o Estado não é uma estrutura monolítica. Seguirei a perspectiva sistematizada por Silvia Aguião (2014), que parte do debate clássico das ciências sociais e políticas sobre a relação entre Sociedade Civil e Estado para compreender a inserção no Estado do movimento LGBT. O grupo de travestis e transexuais estudado, apesar de confrontar-se com um Estado que se apresenta para elas como violento e as coloca às margens da cidadania, atua também simultaneamente numa relação de relativa inclusão por intermédio de agentes públicos que são acessados por esta rede de relações políticas existentes.

Portanto, a pesquisa buscou elucidar os modos através dos quais se produz e se vive a política feita nas margens, ou seja, as estratégias adotadas pelas travestis frente às

\footnotetext{
${ }^{1}$ As complexas classificações de identidade das mulheres trans transcendem definições puramente científicas, sendo sempre muito fluídas, contextuais e políticas. Deste modo, uso provisoriamente as classificações adotadas pelas meninas que conversei residentes na Casa de Alice, sendo que há uma preferência hegemônica neste contexto pela adoção da categoria travesti, o que discutiremos mais à frente.
} 
problemáticas que lhe são próprias, especialmente o acesso à educação, a saúde, as técnicas de transformação corporal e, por fim, o enfrentamento da violência transfóbica cotidiana empreendida pelos agentes estatais e outros atores sociais.

Mais especificamente, o trabalho que se apresenta a seguir é resultado da etnografia que realizei no Jardim Itatinga. Desde 2013, observei o cotidiano de uma residência coletiva de travestis e transexuais: o Pensionato de Juliana e Alice. Sendo assim, o texto que apresento foi construído mediante as experiências etnográficas que vivenciei nesta localidade e que narro brevemente nesta Introdução.

O contato inicial com o pensionato ocorreu por intermédio de um curso de inglês comunitário no bairro. A ideia do curso de inglês foi inicialmente de Bethânia, mulher $\mathrm{cis}^{2}$, militante da Associação Mulheres Guerreiras, e visava oferecer uma formação para as profissionais do sexo do bairro diante das expectativas de mercado frente a aproximação da Copa do Mundo de Futebol. Portanto, inspirado na proposta de Bethânia o formato do curso foi idealizado por Letizia Patriarca, minha colega da turma de 2013 no curso de mestrado do Programa de Pós-Graduação em Antropologia (PPGAS) na USP, por Denise Martins, travesti militante da Associação Mulheres Guerreiras, e por mim. O curso teve início em Setembro de 2013. As aulas de inglês contaram com o suporte material do CEPROMM (Centro de Promoção da Mulher Marginalizada), que nos ofereceu o espaço físico. O CEPROMM é uma ONG católica, que atua no local, através do oferecimento de oficinas de apoio a aprendizagem para crianças e adolescentes que residem no bairro, de creche em período integral, além de disponibilizar seu espaço para projetos e eventos de interesse da comunidade.

Foi através de Letizia Patriarca, que já realizava pesquisa na região estudando as relações trabalhistas entre donas de casas de prostituição e profissionais do sexo, que conheci esta comunidade. O projeto de pesquisa de Letizia Patriarca (2013) tinha inspiração nas disputas entre setores do movimento feminista que consideram a prostituição uma exploração degradante da mulher e do movimento organizado de prostitutas, que defende a autonomia das profissionais do sexo na escolha desta carreira, bem como a conquista de direitos trabalhistas que ofereçam dignidade e combatam o

\footnotetext{
${ }^{2}$ Termo criado como contraponto à palavra trans, sendo cis uma pessoa cujo o gênero corresponde ao sexo biológico.
} 
estigma da profissão. Em Campinas, as profissionais do sexo se organizam por intermédio da Associação Mulheres Guerreiras, que faz parte da Rede Nacional de Prostitutas. Uma das propostas do movimento de prostitutas é legalizar as casas de prostituição, pois estas oferecem suporte ao exercício da profissão, possibilitando um local de trabalho seguro.

Esta demanda resultou no conteúdo do projeto do deputado federal Jean Willys, o Projeto de Lei 4.211/2012, que ficou conhecido como PL Gabriela Leite. Gabriela, que faleceu em 2013 em decorrência de um câncer, foi prostituta e fundadora da Ong Davida, instituição que defende os direitos de profissionais do sexo, tendo sido também presidente da Rede Nacional de Prostitutas, organização nacional que congrega as Associações de Prostitutas pelo país.

Quanto ao referido PL, que visa regulamentar a atividade dos profissionais do sexo, é importante ressaltar alguns de seus artigos, uma vez que o debate a seu respeito se fez presente de diferentes formas ao longo do trabalho de campo:

Art. $1^{\circ}$ - Considera-se profissional do sexo toda pessoa maior de dezoito anos e absolutamente capaz que voluntariamente presta serviços sexuais mediante remuneração.

$\S 1^{\circ}$ É juridicamente exigível o pagamento pela prestação de serviços de natureza sexual a quem os contrata.

$\S 2^{\circ}$ A obrigação de prestação de serviço sexual é pessoal e intransferível. Art. $2^{\circ}$ - É vedada a prática de exploração sexual.

Parágrafo único: São espécies de exploração sexual, além de outras estipuladas em legislação específica:

I- apropriação total ou maior que $50 \%$ do rendimento de prestação de serviço sexual por terceiro;

II- o não pagamento pelo serviço sexual contratado;

III- forçar alguém a praticar prostituição mediante grave ameaça ou violência.

Art. $3^{\circ}$ - A/O profissional do sexo pode prestar serviços:

I - como trabalhador/a autônomo/a;

II - coletivamente em cooperativa.

Parágrafo único. A casa de prostituição é permitida desde que nela não se exerce qualquer tipo de exploração sexual.

Art. $4^{\circ}$ - O Capítulo V da Parte Especial do Decreto-Lei no 2.848, de 7 de dezembro de 1940, Código Penal, passa a vigorar com as seguintes alterações:

Art. 228. Induzir ou atrair alguém à exploração sexual, ou impedir ou dificultar que alguém abandone a exploração sexual ou a prostituição.

"Casa de exploração sexual".

Art. 229. Manter, por conta própria ou de terceiros, estabelecimento em que ocorra exploração sexual, haja, ou não, intuito de lucro ou mediação ação direta do "Favorecimento da prostituição ou da exploração sexual" 
do proprietário ou gerente.

"Rufianismo".

Art. 230. Tirar proveito de exploração sexual, participando diretamente de seus lucros ou fazendo-se sustentar, no todo ou em parte, por quem a exerça.

Art. 231. Promover a entrada, no território nacional, de alguém que nele venha a ser submetido à exploração sexual, ou a saída de alguém que vá exercê-la no estrangeiro.

Art. 231-A. Promover ou facilitar o deslocamento de alguém dentro do território nacional para ser submetido à exploração sexual.

Art. $5^{\circ}$. O Profissional do sexo terá direito a aposentadoria especial de 25 anos, nos termos do artigo 57 da Lei 8.213, de 24 de julho de 1991. (Texto do Projeto de Lei Gabriela Leite retirado do Site da Câmara dos Deputados Federais: http://www.camara.gov.br/proposicoesWeb/prop_mostrarintegra?codteo $\mathrm{r}=1012829$ )

Letizia e eu resolvemos visitar o Jardim Itatinga em meados de Julho de 2013 e propor a comunidade um curso de inglês como uma troca ou retorno para nossa presença como pesquisadoras. A questão inicial que eu havia proposto no projeto de pesquisa apresentado na seleção para ingresso no mestrado, foi se transformando neste processo. Se inicialmente eu tinha como proposta trabalhar a questão de como o sistema de saúde atendia as demandas por transformação corporal das travestis, durante o trabalho de campo constatei de que o acesso à educação formal e o enfrentamento da violência também eram demandas centrais no cotidiano deste grupo de travestis.

O trabalho de Larissa Pelúcio (2007) intitulado Nos nervos, na carne, na pele: uma etnografia sobre prostituição travesti e modelo preventivo de AIDS, foi especialmente importante para a elaboração de meu projeto de pesquisa e posteriormente para o levantamento de questões no decorrer do trabalho de campo. Em sua tese de doutorado, a autora notou que as políticas públicas que tinham como alvo travestis e transexuais, especialmente no âmbito da Saúde, ainda estavam muito restritas aos programas de prevenção de DST/AIDS, não havendo uma preocupação política no sentido de atender outras demandas de saúde que são específicas deste grupo social, como a transformação corporal. Este processo político acaba reforçando os estigmas de marginalização e patologizam historicamente no Brasil as mulheres trans. No início, portanto, eu visava analisar como estas demandas por transformação corporal das mulheres trans estavam sendo incorporadas no Sistema Único de Saúde em razão da crescente mobilização do Movimento LGBT em relação a esta questão específica. 
Já em nossa primeira visita, fomos recepcionadas por Denise Martins, que é a atual presidente da Associação Mulheres Guerreiras e possui uma longa de trajetória de militância no movimento LGBT e feminista, além de já ter atuado como agente em políticas públicas destinadas ao bairro e à comunidade de travestis local. Porém, Denise tem que conciliar suas atividades militantes como o trabalho de diarista, pois atua como faxineira e cozinheira em várias casas no Jardim Itatinga e na região. Esta conciliação nem sempre é fácil, ela conta que chegou a ouvir uma vez de uma "patroa" que deveria decidir entre o trabalho e a militância. No entanto, ela vem resistindo com sua habilidade de lidar com conflitos e as pressões de ambos os lados.

Denise recebeu com entusiasmo a proposta do curso de inglês e negociou rapidamente com o CEPROMM a sala que utilizamos para as aulas até Dezembro de 2013. Após esta data começamos a usar o pátio do pensionato de Juliana, pois o CEPROMM precisou demolir a sala de aula que utilizávamos para ampliar a creche.

Utilizei a noção de dádiva no título desta introdução tendo como pressuposto a análise de Marcel Mauss (2003) sobre o papel da troca nas relações sociais. Para o autor, a dádiva é caracterizada como um fato social na qual consta a obrigação de dar, de receber e de retribuir, pois ao dar um objeto (presente ou parcela simbólica), o doador cria uma obrigação face ao receptor, que tem a obrigação de receber e deve posteriormente retribuir, sendo que as doações recíprocas estabelecem relações de aliança, hospitalidade, proteção, assistência mútua ou mesmo de hostilidade, se a coreografia das expectativas for quebrada, por exemplo.

Na perspectiva de Marcel Mauss, as trocas são de especial interesse, pois há no oferecimento das prestações um caráter voluntário, aparentemente livre e gratuito, mas que é obrigatório e interessado. $\mathrm{O}$ autor questiona qual a força que obriga o oferecimento desta contraprestação uma vez que o dom oferecido era aparentemente gratuito. A troca, deste modo, é anterior à própria instituição dos mercados e dos mercadores, bem como da invenção da moeda, e neste sentido, o autor propõe analisar a moral e a economia que regem essas transações puramente mediadas pela dádiva. Assim, para estudar o fenômeno da troca, Marcel Mauss utilizou uma metodologia comparativa com materiais etnográficos advindos de várias culturas.

Entre os polinésios, por exemplo, foi possível observar um sistema de prestações 
totais no qual as doações, aparentemente voluntárias, ocorrem por intermédio de presentes e agrados, sendo entretanto de caráter obrigatório. O potlatch das tribos do noroeste americano é uma destas formas de prestações totais, na qual o princípio da rivalidade e do antagonismo culminam com a destruição e doação das riquezas acumuladas para demonstrar superioridade em relação aos rivais, ou seja, a contraprestação e a prestação visam assegurar a hierarquia entre nobres e consequentemente a dos seus respectivos clãs.

Em Samoa, o potlatch possui duas características fundamentais: a primeira delas é a honra e o prestígio conferido ao doador denominado de mana e é implícita a obrigação absoluta de retribuir as dádivas sob pena de perder este mana. Recusar dar, receber e retribuir é o equivalente a uma declaração de guerra, pois é a recusa da aliança. Deste modo, todas as instituições nessas sociedades pautadas pela troca pressupõem que tudo (incluindo alimentos, mulheres, filhos, bens, talismãs, solo, trabalho, serviços, ofícios sacerdotais e funções) é passível de transmissão, de prestação e contraprestação.

A partir deste exemplo etnográfico, o autor irá utilizar o termo dádiva para descrever esse tipo de prestações totais, bem como o termo mana, como o atributo adquirido mediante estas transações que confere status aquele que doa e obriga aquele que recebe a retribuir. Mauss dedica-se, sobretudo, às implicações morais da troca, pois a considera uma das pedras fundamentais a partir das quais se constrói o social.

Se coisas são dadas e retribuídas, é porque se dão e se retribuem "respeitos" - podemos dizer igualmente, "cortesias". Mas é também porque as pessoas se dão ao dar, e, se as pessoas se dão, é porque se "devem" - elas e seus bens - aos outros (Mauss, 2003, p. 263).

Ou seja, quando trocamos não é apenas os termos das trocas que são importantes, mas também a relação de aliança que é estabelecida, pois ao trocarmos damos algo de si próprio para o outro, transformando-nos enquanto sujeitos no transcorrer desta transação.

Utilizar a noção de dádiva para descrever esta troca que estabelecemos com a comunidade de travestis, transexuais e mulheres deste bairro é interessante, pois ela oferece a possibilidade de reconhecermos a dádiva advinda deste tipo de relação. Como veremos ao longo desta dissertação muitas das relações do bairro, por intermédio de suas militantes, com as redes de movimentos sociais, acadêmicos, artísticos, religiosos, de políticos profissionais e agentes do Estado também são mediadas por uma certa noção de dádiva, na 
qual estes grupos, ao acessarem o bairro por interesses variados, oferecem contraprestações importantes na construção da visibilidade política dos atores sociais que ali trabalham e residem.

A dádiva que recebi nesta troca, que visava à construção desta dissertação, transcendeu o próprio sentido de um texto acadêmico, pois fui me transformando como educadora sensibilizada ainda mais pelas questões de gênero na educação, uma vez que sou professora de Sociologia na Rede Estadual de Educação. Minhas experiências etnográficas foram muitas vezes um importante insumo na elaboração de aulas, construção de projetos e debates políticos no interior da Escola e no Sindicato, como representante da Apeoesp o sindicato estadual de professores - na ocasião da militância pelos Planos Municipais e Estadual de Educação.

Esta troca, que entendo como uma dádiva, com a militância do bairro com as redes que com elas se conectam também produzem efeitos interessantes, como a possibilidade de transcender apenas a contrapartida da visibilidade política e oferecer a dimensão de uma educação para consciência social. A nossa anfitriã no bairro, dada a sua posição militante, é uma figura especial, pois é uma educadora em termos da conscientização política das travestis e transexuais da região oferecendo às meninas uma perspectiva política e cultural especifica por conta das alianças estratégicas que ela constrói com os setores públicos, pesquisadores, a militância feminista, a LGBT e artistas.

O pensionato de Juliana é uma residência coletiva de travestis, sendo que algumas de suas moradoras decidiram frequentar o curso de inglês, especialmente pela influência de Alice "a Mãezinha", que, após receber a informação da existência do curso através de Denise motivou as meninas da casa a se matricularem nas aulas. Alice é uma travesti que trabalha para Juliana na organização das tarefas domésticas da casa, mantendo a ordem em relação à limpeza e à produção das refeições, mas também tendo como função garantir uma boa convivência entre as moradoras, observando a disciplina das mesmas na obediência das regras acordadas neste coletivo. Juliana também possui esta função disciplinar, no entanto, a "Mãezinha" a exerce com mais legitimidade dado sua liderança pacificadora e afetuosa. Para as aulas de inglês, como incentivo à participação de meninas do pensionato, Alice foi ao supermercado e comprou um caderno para cada uma das travestis que frequentasse a aula. 
Vieram de outra residência coletiva, a de Mariuza, algumas alunas mulheres e travestis, compondo uma turma heterogênea e numerosa, no início com 12 discentes, mas que, ao longo de cerca de um ano, dadas as dificuldades de aprendizagem e a escassez de tempo para o estudo, esvaziou-se consideravelmente. Mariuza também administra uma residência coletiva, ou seja, um "pensionato" como denominado por suas moradoras. Mariuza é responsável pela organização dos afazeres domésticos e fornece três refeições diárias para suas hóspedes, mediante o pagamento de uma diária. Como veremos ao longo desta dissertação, o pensionato, nestes moldes de um lugar para dormir e fazer as refeições, é um dos modelos de organização social da localidade. A residência coletiva, ou pensionato, distingue-se da casa de prostituição, pois a segunda tem como característica distintiva o fato de possuir quartos para o atendimento de clientes.

O bairro já foi objeto de estudo de inúmeros pesquisadores de diferentes áreas das ciências humanas desde sua criação, incluindo a arquitetura e urbanismo, a antropologia, o jornalismo, a educação e até mesmo a teologia (Regina M. Mazzariol, 1977; Karolina Bahia, Larissa Luizari e Nara Faria, 2003; Paulo Reis dos Santos, 2008; Luiz Carlos Sollberger Jeolás, 2009; Diana Helene, 2012; dentre outros). Portanto, os moradores desta região já se acostumaram com a presença e mesmo o assédio dos pesquisadores que se tornaram parte da dinâmica local, e são, como diria Denise, "os estudantes". Esta presença, no entanto, também gera conflitos, seja por trabalhos que não resguardaram o anonimato das pessoas que posteriormente sofrem algum tipo de constrangimento, ou ainda, da expectativa de determinados atores que os trabalhos acadêmicos produzam algum resultado no campo político, pela visibilidade das questões específicas do bairro e de sua comunidade de travestis e prostitutas, como um bom argumento para o atendimento de reivindicações. Assim, é nesta lógica da visibilidade e da militância que Denise acolhe os "estudantes", sendo ela mesma a informante preferencial de muitos estudos nos quais é citado o seu nome. "Coloque Denise Martins no 'Google Acadêmico' e vai aparecer um monte de texto", brinquei com ela certa vez quando conversávamos sobre os vários trabalhos com que já colaborou, e ela citou muitos, inclusive um trabalho produzido na área da teologia pelo pároco da região, o padre João.

Redigir esta dissertação demandou a construção de um arcabouço literário que permitisse do modo mais fidedigno possível expressar as experiências que vivenciei na 
observação deste contexto, com especial atenção às questões éticas e metodológicas que foram despontando ao longo do tempo de trabalho.

Para Marilyn Strathern (2014) tempo, mais que o espaço, tornou-se uma característica distintiva da etnografia. Portanto, não importa onde se localiza geograficamente o campo nem sua extensão, bem como se este se dá no ambiente virtual ou real, pois a questão está na temporalidade que separa o campo da escrita etnográfica.

O trabalho de campo, neste sentido, é uma atividade complexa, pois envolve além da observação um trabalho posterior de reelaboração por meio da escrita. Para a autora, "a escrita só funciona se ela for uma recriação imaginativa de alguns dos efeitos da própria pesquisa de campo" (Strathern, 2014, p.346). Assim, as narrativas que faziam sentido no interior da pesquisa de campo devem ser rearranjadas de modo a fazer sentido para os pares da comunidade científica em termos analíticos e argumentativos. Deste modo, a relação entre dois campos, a pesquisa e a escrita, é do tipo complexo, pois, apesar de se conectarem entre si, possuem características que lhes são próprias. Sendo que cada campo possui uma orientação, pode haver um sentido de perda e deslocamento de uma dimensão para outra, como observado por Strathern:

[...] a compreensão de que nenhum deles jamais estará em conformidade com outro é uma experiência antropológica comum. Assim, torna-se uma espécie de premonição talvez levar à perda consigo. (Strathern, 2014, p.346).

Portanto, esses campos são criadores um do outro, porém cada um possui sua especificidade com dinâmicas que lhes são próprias. Aquilo que fazia sentido no projeto de pesquisa, no campo pode ser observado de forma diferente das hipóteses propostas, e assim, o campo constrói novas demandas de escrita e análise. Neste deslocamento entre dois campos encontrei-me com o debate sobre a política da escrita antropológica e de suas apresentações literárias da experiência de campo, especialmente na dimensão da apropriação ética dessas realidades sociais do outro.

Como exposto acima, a produção etnográfica, apropriando-se da análise de Strathern, foi marcada nesta pesquisa pela transformação de meus objetivos, pois a etnografia desta coletividade trans me oferecia novos dados e questões acerca do universo social estudado, repensados nos momentos de anotações no caderno de campo e escrita dos 
esboços desta dissertação, o que implicou também novas escolhas teóricas e analíticas. Finalmente, a escrita final foi uma tarefa árdua de reelaboração criativa acerca deste ano de observação etnográfica do bairro e pensionato.

Durante três semestres de aulas e observações, vivenciei experiências etnográficas marcantes que levantaram questões acerca da construção do corpo e das classificações trans dos debates políticos acerca da prostituição, e da existência do bairro como espaço segregado e da liminariedade. Principalmente sobressaíram-se durante nesses meses de campo os temas da saúde, educação e violência no contexto das travestis.

A saúde, como já explicitado, era o objeto inicial da minha entrada em campo. A educação, por sua vez, foi uma questão apresentada a partir das dificuldades pedagógicas que enfrentamos ao ensinar inglês para um coletivo de alunas com níveis de escolarização diferenciados. Estas dificuldades de ensino e aprendizagem foram decorrentes do fato que parte considerável de nossas interlocutoras do curso e da residência coletiva de Juliana e Alice haviam tido um acesso precário ao ensino formal. Este tema tornou-se ainda mais relevante quando, na escola estadual onde trabalho, presenciei o abandono dos estudos por uma aluna transexual diante do contexto hostil e transfóbico que enfrentara.

Por fim, a violência, especialmente aquela perpetrada pelo Estado, foi uma experiência de campo desagradável, porém elucidativa acerca do Itatinga. A questão da violência policial foi marcante neste ano de observação etnográfica, especialmente no momento que o bairro sofreu uma invasão da PM diante da morte de um agente nesta região. Revelou-se neste momento uma das faces que o Estado pode assumir nesta localidade e em relação às mulheres e pessoas trans: autoritário e perpetrador da violência.

Diante disto, foi necessário investigar o Estado nos múltiplos modos em que é vivenciado no bairro e por esta coletividade de travestis e transexuais: seja por meio da dimensão autoritária que este assume em determinados contextos e por agentes públicos específicos, ou pela faceta que este adquire ao se articular com os movimentos sociais LGBT, feminista e de prostitutas.

Porém, nosso trabalho também se deparou com uma gama de militantes defendendo o reconhecimento tanto de direitos trabalhistas para as prostitutas, quanto de direitos específicos às pessoas trans, como um acesso adequado e específico à saúde, ao registro civil, à educação e finalmente a um tratamento mais humano por parte dos agentes estatais, 
especialmente a polícia. Estas militantes nos receberam em campo de braços abertos tanto pela nossa dádiva de um curso de inglês, quanto pela possibilidade de transmissão, através da produção acadêmica, de suas realidades e reivindicações políticas.

A etnografia, como sugere James Clifford (1998), deve ser analisada em conjunto com os debates político-epistemológicos sobre a escrita e a construção da alteridade. A questão central que emerge destes debates é como o relato escrito de uma experiência intersubjetiva incontrolável, atravessado por relações de poder e interesses individuais, adquire legitimidade científica. A dialética entre experiência e interpretação marca a produção etnográfica e produção antropológica.

A etnografia, no entanto, é o resultado entre a negociação do pesquisador e aqueles que o recebem no grupo cultural que se pretende estudar, sendo uma relação criativa e com atores politicamente relevantes (Clifford, 1998, p.43). Neste sentido, os paradigmas de experiência e interpretação estão cada vez mais sendo substituídos por paradigmas de diálogo e polifonia. Segundo Bakhtin (citado por Clifford, 1998, p.44) "não há nenhuma palavra ou forma neutra, palavras ou formas que podem não pertencer a ninguém; a linguagem é completamente tomada e atravessada por intenções e sotaques". E foi por esta lógica que, de modo intuitivo, negociamos nossa presença como pesquisadoras, por intermédio de um curso de inglês oferecido à comunidade, havendo nisto um sentido de construir uma certa reciprocidade entre pesquisadores e pesquisados através da troca. Nossa recepção no campo, como veremos ao longo desta dissertação, também tinha a ambição semelhante acerca da visibilidade das demandas e dos discursos de quem nos recepcionava. Nesta linha, lembro-me das horas que passava conversando com uma militante da Associação sobre as estratégias e alianças que ela considerava importante adotar para atingir os objetivos da luta e provavelmente imaginava que de uma maneira ou outra eu escreveria sobre o assunto, sendo o papel dela fornecer o maior número de dados possíveis para preencher meu estudo e informar pela via acadêmica as demandas do grupo da qual fazia parte.

Notei esta mesma percepção, de que as relações entre "nós e os outros" devem ser mediada eticamente pela reciprocidade, diante da indignação de uma militante da Associação ao receber uma carta-convite para um evento sobre prostitutas em Campinas. O evento seria organizado por um grupo de advogados, porém estava ausente no texto do 
convite o nome da Associação. Ela desabafou comigo e com outras colegas presentes na ocasião e disparou: "por que chamar as putas sem colocar o nome da Associação? Que petulância!”.

No entanto, etnografias dialógicas que reconhecem esta negociação intersubjetiva da experiência de campo entre pesquisador e pesquisado, ainda assim continuam sendo representações do diálogo (Clifford, 1998, p.46) com armadilhas textuais clássicas como a representação da parte pelo todo e a homogeneização dos atores descritos.

A estratégia de dar voz aos atores é complexa diante de uma tradição cultural literária ocidental marcada pela organização do texto segundo a intenção de único autor (Clifford, 1998, p.55). Portanto, este trabalho enfrenta o desafio de dar visibilidade às demandas dos atores sociais (direitos das prostitutas, nome social das travestis, etc.) e dos modos como de organização para atividade política (associação, paradas, passeatas, intervenções artísticas e assim por diante), mas, ao mesmo tempo, proteger estes mesmos atores diante dos horizontes éticos e metodológicos enfrentados. Sendo assim, este trabalho é uma construção literária que pretende apresentar, através das experiências vivenciadas em campo, aquilo que é relevante em relação ao universo estudado.

Na percepção de Clifford (1998, p.63), a etnografia é uma performance com enredo estruturado através de histórias poderosas e são estas histórias vivenciadas em campo, algumas cotidianas e outras extraordinárias, que apresento neste trabalho.

Assim, como será visto a seguir a dissertação está organizada em um primeiro capítulo, intitulado "O Itatinga: A segregação e a criação de um 'parque temático", que descreve o bairro e suas especificidades em termos sociais e históricos, apresentando também o Pensionato de Juliana e Alice, sua arquitetura e moradoras. Neste capítulo, pretende-se descrever o modo como se constroem as relações sociais no cotidiano do bairro, os atores que o compõem a complexidade deste espaço social, especialmente a coletividade trans reunida nesta residência administrada por Juliana e Alice, mas também as posições ocupadas no discurso e prática política do CEPROMM, ONG local já mencionada, e da Associação Mulheres Guerreiras, a associação de prostitutas da cidade.

No segundo capítulo, "Como se faz e se vive a política desde as margens", analiso o modo como são vivenciadas e construídas as demandas políticas por cidadania no cotidiano das travestis e transexuais do bairro, tais como a questão da saúde e do combate 
à violência transfóbica, apresentando as estratégias de ação política empregadas pelas moradoras desta localidade, incluindo as performances de reivindicação adotadas. Neste mesmo sentido, apresento as redes que conectam o bairro à cidade, sejam elas acadêmicas, artísticas, religiosas e aquelas compostas por movimentos sociais, por políticos profissionais e agentes do Estado, analisando o modo como estas redes são articuladas nas estratégias deste fazer político vivenciado a partir das margens. Portanto, neste mesmo capítulo estudo como o Estado é vivenciado e como este assume múltiplas facetas no interior deste contexto.

Reservo à educação um capítulo especial que intitulei de "A educação para uma transcidadania", pois minha entrada em campo foi justamente dada pelo ensino de inglês, experiência na qual verifiquei as dificuldades de aprendizado decorrentes da exclusão da educação formal destas meninas trans. Partindo disto, descrevo as trajetórias escolares de uma aluna travesti em um curso de Educação de Jovens e Adultos (EJA) do pensionato de Juliana e de uma aluna transexual da escola em que trabalho, apresentando o modo como a escola é vivida por essas pessoas trans. Por fim, alargo a noção de educação para além dos muros da escola, descrevendo como são educadas as meninas do pensionato de Juliana e Alice, tanto dentro da noção de parentesco trans ali compartilhado, como pelo intermédio da noção de cidadania e ação política apresentada na convivência com a militância, especialmente trans. Como será visto, minha experiência como professora de Sociologia da Rede Estadual de Educação, também foi determinante na construção deste capítulo.

As "Classificações trans", apresentadas no último capítulo, contêm uma descrição destas categorias por intermédio do vocabulário próprio das meninas do pensionato, compreendendo o papel político e contextual desta semântica que atravessa a descrição de comportamentos sociais e perpassa as definições de quem seria elas próprias dadas suas características específicas. Assim, percorremos uma miríade de classificações acerca das diferenças construídas historicamente entre transexuais e travestis, também tendo em vista como essas diferenças se articulam com os marcadores sociais da diferença em termos de raça, gênero e classe social para, finalmente, compreender como estas classificações são acionadas no contexto específico do pensionato e do bairro, fazendo parte dos componentes desta educação informal nesta residência coletiva e na militância trans.

Na conclusão, "A política da "Locas" e a política das trocas", retomo o elemento 
das estratégias adotadas pelas prostitutas e mulheres trans de atuação política militante observadas no campo. Nesta lógica, levanto questões acerca das potencialidades de agência dos movimentos sociais LGBT e feminista, através de estratégias locais e criativas, frente ao atual cenário político nacional de ofensiva conservadora encabeçada por políticos profissionais que ganham cada vez mais visibilidade e influência nos níveis de elaboração de políticas públicas. 


\title{
CAPÍTULO 1. O Itatinga: A segregação e a criação de um "parque temático"
}

\begin{abstract}
A segregação espacial da prostituição se define através de múltiplos processos segregatórios que se combina, se articulam se entrecortam, e assume características singulares em função dos contextos políticos, sociais, econômicos e culturais (Feldman, 1989, p. 56).

$\mathrm{Na}$ linguagem habitual, podemos dizer que as "pessoas margens" (marginais) são as vítimas de uma segregação e são cada vez mais controladas, vigiadas e assistidas na sociedade (ao menos nas mais desenvolvidas). É aquilo a que se refere Foucault com a expressão Vigiar e Punir. (Rolnik e Guattari, 1996, p.122).

Passando pelo Itatinga li a placa em voz alta, o motorista do taxi prontamente me alertou "Senhora, não vá aí, é um lugar muito perigoso". (Gabriela Leite em evento na Unicamp do Cine Pagu sobre o filme "um beijo para Gabriela", 20/06/2013).
\end{abstract}

Este capítulo tem como finalidade analisar a especificidade do Jardim Itatinga enquanto espaço urbano de segregação da prostituição e de marginalização a partir da perspectiva da antropologia urbana e dos marcadores sociais da diferença. Deste modo, utilizando-se da observação etnográfica pretende-se apontar o modo como se constroem as relações sociais no cotidiano do bairro, os atores que tecem a complexidade deste espaço social, especialmente a coletividade trans reunida no pensionato de Juliana e Alice, mas também as posições ocupadas no discurso e prática política do CEPROMM, uma ONG local e da Associação Mulheres Guerreiras, a associação de prostitutas da cidade.

A residência coletiva, como veremos, é uma das formas por meio das quais se estrutura o bairro, possuindo vários formatos que têm em comum o fato de abrigarem profissionais do sexo, oferecendo alimentação e moradia em troca do pagamento de diária. Na residência em foco aqui, Alice, é contratada de Juliana para realizar estas atividades de manutenção e administração da residência, sendo conhecida carinhosamente por "Mãezinha".

Como já havia sido exposto na Introdução, Denise Martins é a presidente da associação de prostitutas local (Associação Mulheres Guerreiras) e foi nossa anfitriã quando eu e Letizia chegamos ao bairro, recebendo entusiasmada nossa proposta de realização de um curso de inglês comunitário em troca de nossa presença como 
pesquisadoras. Pela intermediação de Denise o CEPROMM (Centro de Promoção da Mulher Marginalizada), uma ONG detentora de um amplo espaço físico no Itatinga, nos ofereceu uma sala de aula.

No site ${ }^{3}$ do CEPROMM, ONG criada em 1993, consta que a missão deste é proporcionar meios que favoreçam vida plena às crianças, adolescentes e mulheres em situação social de risco, especialmente os expostos ao abuso e exploração sexual. A creche e as oficinas de esportes, inclusão digital, orientação profissional, jogos pedagógicos e de artes são uma das suas principais atividades, atendendo as crianças e adolescentes do bairro, e possuindo uma grande demanda por vagas. O posicionamento da ONG de oferecer suporte à "mulher marginalizada" é resultado do pressuposto que as profissionais do sexo estariam nesta condição por falta de oportunidades educacionais e empregatícias. Portanto, a ONG é distinta da Associação Mulheres Guerreira, que parte da premissa da autonomia da mulher na escolha de sua trajetória como profissional do sexo e da necessidade da luta contra o estigma da profissão reivindicando melhores condições de vida e trabalho.

Apesar desta diferença em termos do posicionamento político em relação à prostituição a ONG estabelece parcerias, afinal nos ofereceu espaço para o curso de inglês direcionado a mulheres cis e trans, disponibilizou o espaço físico e o apoio institucional em Junho de 2014 para que a defensoria pública realizasse um evento sobre a "mudança de nomes" para travestis e transexuais, bem como sua quadra poliesportiva para o fechamento do evento com uma peça de teatro sobre o Itatinga feita pelos alunos do $3^{\circ}$ ano de Artes Cênicas da Unicamp.

Ocupamos o espaço concedido pelo CEPROMM de Setembro de 2013 a dezembro do mesmo ano, após esta data a sala que utilizávamos foi demolida para ampliação da creche, e continuamos o curso de inglês no pátio do pensionato de Juliana. Deste modo, no curso, residência coletiva e bairro, observamos os anseios, estratégias e problemáticas em relação ao Itatinga, a prostituição e a construção de um corpo feminino pelas travestis e transexuais que habitavam o pensionato de Alice e Juliana.

Dentre as questões preliminares levantadas neste contanto inicial com o campo estavam a especificidade de atuação do posto de saúde local, uma vez que se tratava de um bairro que se estrutura exclusivamente em torno da prostituição. Este posto de saúde,

\footnotetext{
${ }^{3}$ Ver http://www.cepromm.com.br/.
} 
localizado numa rua de terra, ainda na entrada do bairro, possui um prédio simples e desgastado pelo tempo. No seu interior, médicos e agentes de saúde atendem pacientes com problemáticas das mais variadas, e provavelmente encontrada em tantos outros postos de saúde. O que diferencia este posto é justamente sua clientela, formada marjoritamente por prostitutas. Dentro deste contexto, existe uma atenção especial da unidade em relação à prevenção e tratamento de DST/AIDS, com o monitoramento da saúde de seus pacientes através de consultas médicas e exames, a visita da equipe de agentes de saúde às pessoas em seu local de moradia ou estadia, a distribuição de preservativos, dentre outras atividades. De acordo com as meninas da Casa a médica ginecologista, que atende as quintas-feiras pela parte da manhã, também oferece aconselhamento em relação à hormonoterapia e há um trabalho de conscientização acerca do silicone industrial. O posto também é o espaço de eventos comunitários, seja em relação às próprias questões de saúde de travestis e prostitutas, ou ainda, relativos a outros temas mobilizados pelo interesse da comunidade.

Outra questão interessante eram as estratégias de transformação corporal utilizadas pelas travestis do bairro e como o pensionato influenciava na construção deste processo. $\mathrm{Na}$ compreensão desse tema, era necessário identificar qual seria o papel do sistema de saúde na produção destes corpos, inclusive por meio da atuação do posto de saúde local.

Por fim, outra questão que ofereceu novos trajetos para minha pesquisa advém da experiência de ter observado a ocupação do bairro pela polícia militar em Outubro de 2013. Em decorrência da morte de um policial nas proximidades do Jardim Itatinga a polícia invadiu o bairro violentamente em busca de suspeitos, agredindo moradores e comerciantes, e estabelecendo um "toque de recolher" de vários dias, somente desocupando esta vizinhança após o protesto das profissionais do sexo local na Rodovia Santos Dumont. Nesta ocasião a Casa de Juliana também foi invadida, sendo que as meninas residentes foram vítimas de violência física e psicológica, algumas destas como uma ênfase homofóbica.

A partir destes pontos levantados em campo, a questão da forma como o Estado nas suas múltiplas faces aparece para estas vivências e na organização do espaço do bairro, tanto da prostituição quanto da travestilidade, tornou-se central para a reflexão que construo acerca de minhas experiências etnográficas. Afinal, de um lado temos o Estado 
como instância de reivindicação de direitos acionados pelos movimentos sociais na qual o bairro e a coletividade trans em questão se relacionam nas múltiplas redes da qual fazem parte, por outro lado, uma dimensão distinta do Estado emerge em contextos de violência como exposto acima transparecendo outro tipo de relacionamento com o bairro e suas moradoras.

Assim, diante do tipo de relação que o bairro e os grupos sociais que nele se inserem estabelecem com o Estado mostrou-se produtivo analisá-lo como estando às margens do Estado, uma vez que este pode adquirir uma faceta autoritária por meio da atuação de agentes públicos específicos como a polícia. Mas também, do modo como estes grupos conseguem se inserir no interior do Estado, por meio de suas demandas em articulação com os circuitos acadêmicos, políticos e culturais das quais fazem parte, e a partir disto construir estratégias de atuação e empoderamento político específicos. Portanto, dividiremos esta análise a partir de duas perspectivas sobre o Estado a fim de descrever a multiplicidade com que este é vivenciado neste local: de um lado temos o Estado como margens na qual adotaremos as perspectivas de Veena Das e Deborah Poole (2008); mas também este como instância dinâmica construída no próprio "fazer político" como apresentado por Silvia Aguião (2014), que debate a relação entre sociedade civil e Estado ${ }^{4}$, utilizando-se de uma ampla discussão teórica para fazer uma etnografia das instâncias de reivindicação política do movimento LGBT.

Também foi necessário descrever a diversidade de atores e relações que compõe o Itatinga, e para tanto utilizamos o conceito de socialidade proposto por Marilyn Strathern (INGOLD, Tim et al., 2005). Socialidade foi um termo cunhado por esta autora para deslocar o sentido contido no conceito ocidental de sociedade como instância inata e que deriva na díade indivíduo e sociedade. A autora propõe que os sujeitos são construídos a partir das relações sociais que estabelecem, e, deste modo, o divíduo é múltiplo e contextual, ou seja, um compósito de relações.

Por fim, tendo em vista a constituição do bairro como espaço urbano confinando, penso a questão das relações sociais que esta localidade estabelece bem como a mobilidade

\footnotetext{
${ }^{4}$ A relação entre sociedade civil e Estado é um dos debates centrais da ciência política, especialmente pata teoria do Estado, incluindo os clássicos trabalhos na teoria marxista que visam perceber a permeabilidade das classes sociais em relação ao Estado como Antônio Gramsci e Nicos Poulantzas.
} 
de seus atores e a conexão com outros espaços e setores sociais que vão para além deste local. É importante ressaltar que este trabalho possui uma inserção em campo em especial, a dizer, o pensionato de Alice e Juliana que reúne parte da coletividade de travestis e transexuais do bairro, e que a partir desta entrada que elaboro esta dissertação.

\section{O bairro}

O Itatinga é uma criação estratégica do poder público nos anos 60 , e tinha como finalidade concentrar as atividades ligadas à prostituição, deslocando-a das regiões centrais de Campinas (Mazzariol, 1977). Nos dias atuais, o bairro é considerado a maior zona de prostituição da América Latina, residindo e trabalhando no local cerca de dois mil profissionais do sexo que exercem suas atividades nas ruas e calçadas, em boates, casas de show erótico, pequenos motéis, bares e prostíbulos onde trabalham mulheres e travestis. $\mathrm{O}$ bairro se localiza às margens da Rodovia Santos Dumont, que conecta o eixo Anhanguera e Bandeirantes aos municípios de Campinas, Indaiatuba, Sorocaba, Salto, Itu e São Paulo.

A prostituição em Campinas, antes da criação do bairro, ocorria em casas que se espalhavam pela cidade, mas também nas ruas, nas vias públicas, em frente a residências, escolas, igrejas, dentro de restaurantes e bares, etc. Portanto, não havia uma área especifica destinada e reconhecida como espaço de prostituição, apesar da maioria dessas casas, bem como das prostitutas de rua, se concentrar no bairro do Taquaral, hoje em dia considerado um bairro nobre, mas na época uma localidade distante do centro da cidade (Mazzariol, 1977, p. 14).

Campinas, no início da década de 1960, era uma cidade pequena restrita ao que hoje é a área central da cidade, possuindo apenas alguns bairros como o do Cambuí, Ponte Preta, Taquaral e Guanabara. Nesta época, no entanto, a cidade começa a expandir seu território através do investimento do poder público na construção de conjuntos habitacionais e loteamentos destinados à classe trabalhadora e distante do centro da cidade, em especial na região sudoeste. Nesta mesma época foi criado o bairro Jardim Itatinga.

O contexto de criação do Jardim Itatinga se insere nos primeiros anos da ditadura militar, nos quais tentava-se estabelecer um projeto conservador em termos de certa "moral" e "ordem". O Estado utilizou-se do planejamento urbano como mecanismo de 
disciplinarização do cotidiano das cidades, e deste modo, a prostituição foi um dos primeiros alvos de intervenção pública em Campinas. Indivíduos que contrariam a valorização de certos espaços da cidade pretendidos pelas classes dominantes como moradores sem-teto, camelôs, catadores de lixo e prostitutas foram ao longo da história das cidades objetos de intervenção de urbanistas e sanitaristas a fim de banir estes grupos de determinados locais (Helene, 2012).

Assim sendo, a atuação do Estado no Brasil em relação à prostituição possui historicamente dois direcionamentos centrais que, segundo Diana Helene (2012, p.12), refletiram-se no modo como se estabeleceu o Itatinga, a dizer, o confinamento da prostituição em territórios específicos e o controle da saúde das profissionais do sexo visando a não propagação de doenças.

Em 1966, iniciou-se em Campinas a chamada "Operação Limpeza", que tinha como finalidade a repressão da prostituição na cidade, realizada através da violência policial, do planejamento urbano e da formação de certo consenso na opinião pública de que era necessária a segregação desta prática. Ao mesmo tempo, ocorreu a negociação das donas de casa de prostituição com o Estado para que estas deslocassem suas atividades fora do perímetro urbano da cidade, indo a sua maioria para o Itatinga. Para forçar o deslocamento das prostitutas de rua do centro para periferia, ocorreu uma grande repressão policial que se sustentava no argumento de estar prevenindo a expansão da sífilis.

De acordo com Karolina Bahia, Larissa Luizari e Nara Faria (2003), aconteceu um movimento dos munícipes contra a prostituição na época, especialmente por meio da mídia, o que permitiu maior eficiência à operação, tendo como finalidade afastar as profissionais do sexo das regiões centrais da cidade que se valorizava no período:

A pressão da sociedade foi efetiva e decisiva. Pessoas enviavam cartas a políticos e compareciam às delegacias de polícia para registrar queixas contra as prostitutas. Nos jornais e nas emissoras de rádio [...] repercutia o descontentamento da sociedade, o que levou editor e radialistas a emprestar apoio à ação que levou ao confinamento. (Bahia, Luizari e Faria, 2003, n.p.).

Porém, a "operação limpeza" não se restringia apenas ao afastamento da prostituição, mas de todos os grupos sociais considerados incômodos pela elite campineira, como as famílias pobres que residiam nos cortiços do centro da cidade e que foram também 
deslocadas. Assim, "a operação limpeza teve por objetivo afastar todas as pessoas que, segundo a elite campineira, não faziam parte do contexto da classe média" (Bahia, Luizari e Faria, 2003, n.p.).

O Jardim Itatinga em 1967 inaugurou sua primeira Casa de Prostituição. Em 1968, já possuía cerca de 20 bordéis e em 1969 concentrava a maior parte das profissionais do sexo da cidade. Atualmente, o bairro possui cerca de 200 estabelecimentos destinados ao comércio sexual. Não encontramos nesta pesquisa um material que reconstitui a história e as respectivas transformações desta região entre o final da década de 1960 até os aos 2000, porém pode-se inferir através do material disponível que esta condição de marginalização e segregação da cidade não é a mesma , pois, apesar do Itatinga ainda estar no imaginário como espaço social de liminaridade e cruzamento de fronteiras, veremos que ele acaba sendo incluído em determinados contextos nas dinâmicas políticas e sociais da cidade com a mediação de uma rede de atores que acessam este espaço motivado por múltiplos interesses.

A relação conflituosa entre as prostitutas e as localidades centrais da cidade é persistente e foi um dos pontos centrais que motivou o trabalho de Paulo Reis dos Santos (2008). O autor, sendo coordenador do Centro de Referência GLTTB da Secretaria Municipal de Assuntos Jurídicos e da Cidadania, fora convidado na condição de militante pelos direitos LGBT para mediar o conflito entre moradores da região do bosque e travestis que trabalhavam nesta área, nas instâncias políticas, como a prefeitura e a câmara dos vereadores, entre 2003 e 2004.

As travestis da cidade utilizavam a região do Bosque para fazer programas, algumas inclusive saiam do Itatinga para exercer a prostituição neste local da região central. Os moradores da região, no entanto, ao considerar a presença das profissionais do sexo incômoda organizaram campanhas nesta época para pressionar a ação da prefeitura, bem como afastar os clientes da região. Por exemplo, construíram uma lista de e-mails que compartilhava as placas dos clientes que frequentavam a região ${ }^{5}$. Com a prefeitura, intermediados pela Vereadora Terezinha, fizerem reuniões públicas com a finalidade de construir mecanismos para afastar o problema. É neste contexto que Paulo Reis do Santos é convocado para intermediar as relações entre moradores e travestis tendo como

\footnotetext{
${ }^{5}$ REI, Gilson. "Internet denuncia clientela da prostituição". Correio Popular, Campinas, p. 4, 22 nov. 2003.
} 
interlocutora entre as travestis uma militante do Itatinga em defesa dos interesses das profissionais do sexo.

Nas reuniões em questão esta militante, apesar de não ser oficialmente convidada, pedia a palavra para se posicionar em relação a presença dela e de suas companheiras no Bosque, chegando a negociar nestas instâncias públicas com os moradores a presença das travestis no bairro, sendo que elas se comprometeram a chegar à região apenas a noite e a se comportarem em termos de roupas e abordagens. No entanto, dado o potencial conflituoso das relações entre moradores e travestis este espaço de negociação mediado por Paulo Reis não perdurou por muito tempo.

O Itatinga, portanto, é uma área na qual a atividade principal exercida é a prostituição ou outras atividades ligadas a ela. Apenas uma pequena parte dos imóveis do bairro são "casas de família", na qual se afixa na fachada da residência um aviso indicando tal condição. Entretanto, a grande maioria dessas pessoas sobrevive indiretamente da prostituição; por exemplo, são arrendatários de casas e/ou exercem alguma função de apoio aos prostíbulos, como de faxineiras, babás, comerciantes e assim por diante.

Os clientes circulam geralmente de carro pelo bairro, em baixa velocidade, até que decidam se aproximar de alguém e negociar um programa, porém há aqueles que visitam o bairro a pé, vindo de ônibus de vários lugares da cidade e da região. Por outro lado, também há uma clientela da "curiosidade" em relação ao bairro formado por homens e mulheres que se dirigem ao local para uma experiência diferenciada de "liminaridade", uma vez que o Itatinga é um espaço que acontece eventos extraordinários para o cotidiano do resto da cidade e da região.

Victor Turner (1974), com base no trabalho de Van Gennep, identificou no processo ritual uma fase liminar, na qual se suspendem os elementos definidores da estrutura social constituindo um período de communitas. Assim, nos contextos de liminaridade, as regras sociais pertencentes à estrutura deixam de existir, produzindo um sentido de communitas, nas quais as hierarquias são suspensas. Estas fases de liminariedade e communitas configuram-se em certos contextos sociais como o ápice do drama social, por meio do qual a ordem social pode ser reafirmada ou ocorrer uma transformação desta estrutura (Turner, 1987). No entanto, como o próprio Turner aponta em Dramas, campos e metáforas: a ação simbólica na sociedade humana, as noções ortodoxas de estrutura social são equivocadas 
ao pressupor que há um sentido estático para o social (Turner, 2008, p.24), sendo que conceitos como de sociedade ou comunidade são complicados por pressuporem um carácter imutável do social. Deste modo, a estrutura social é a consequência da ação dos agentes, sendo a resultante de um processo lento envolvendo a repetição regular de certos atos, em contraste com processos rápidos de certos dramas sociais, especialmente singulares e arbitrários (Turner, 2008, p.39). A communitas ou antiestrutura social é o vínculo que une pessoas fora daquilo que seria considerado uma união normal do ponto de vista da estrutura dada, ou seja, a communitas se caracteriza pela espontaneidade e a liberdade na relação comunitária de um grupo, enquanto que a estrutura é dada pela obrigação, direito, lei, coação e etc. (Turner, 2008, p.43). Portanto, o bairro é significado no imaginário popular como uma realidade liminar, de inexistência dos regramentos socialmente dados em outros contextos sociais da cidade em relação às vestimentas, ao comportamento sexual e assim por diante. E, assim, atravessar as fronteiras físicas do Itatinga já constitui um momento de excitação em decorrência do prazer em cruzar as margens.

Nesta vizinhança as pessoas caminham nuas livremente pela rua, trocam olhares insinuantes com os passantes, fazem "poli dance" em uma estrutura disponível na frente de um prédio comercial, e tomam banho de mangueira em roupas íntimas. Assim, o lugar reside no imaginário popular regional como vitrine dos prazeres, nem que seja apenas o voyeur, sendo uma espécie de "parque temático" da experiência sexual comercializável e diversa. Utilizo a expressão "parque temático" para descrever, não sem ironia, esta visão popular acerca do bairro como espaço de excitação no cruzamento desta fronteira simbólica que ofereceria toda sorte de prazeres e possibilidades de transgressões, porém não tenho a intenção de reproduzir este esteriótipo de lugar desregrado, pelo contrário o Itatinga é um espaço social atravessado por códigos e regras específicas.

O bairro, deste modo, seria uma heterotopia, no sentido definido por Foucault e Miskowiec (1986). Letizia Patriarca (2015) analisa de modo mais aprofundando esta posição de heterotopia do Itatinga em sua dissertação.

As utopias se definem como espaços irreais, sendo uma analogia invertida do espaço real. Porém há lugares na sociedade que são heterotopias, pois, mesmo estando fora de todos os lugares, sendo espaços destinados às margens e aos elementos liminares, estes 
fazem referência aos múltiplos espaços da sociedade, que por meio deles, são representados, contestados e invertidos simultaneamente (Foucault e Miskowiec, 1986). Portanto, a "zona" neste caso, representa o espaço que se contrapõe à normalidade da "boa" sociedade campineira desde sua criação, sendo justamente elaborada para que se afastasse a prostituição da área central. Deste modo, esta região se configura como o espaço da vivência do excepcional, na qual a nudez publica, por exemplo, não é condenada e a comercialização do sexo não é penalizada.

No entanto, como observamos, isto não significa que se trata de um espaço desregrado. Como veremos, o pensionato, por exemplo, uma célula na qual se constrói o bairro, é um lugar regulamentado por uma série de regras. Na residência da "Mãezinha", a exigência do respeito a um conjunto de normas é um dos elementos centrais do cotidiano, garantindo a convivência de um coletivo de trans.

\section{A pensão da "Mãezinha"}

Existem em geral no bairro dois tipos de casa de prostituição, as casas na quais as meninas se exibem em portas e janelas para posteriormente levar os clientes em "quartinhos" ou em motéis e drive-ins, ou ainda, casas nas quais os clientes precisam pagar para entrar e ter acesso às prostitutas (Helene, 2012, p.8), sendo uma das mais famosas nesta linha o "Galo de Ouro". Nestas casas fechadas, os clientes devem entrar para acessar as prostitutas, e as mulheres ganham uma porcentagem do lucro das bebidas consumidas com os clientes.

No entanto, as residências coletivas são uma forma distinta de organização para viabilizar o trabalho no bairro. Os pensionatos se configuram como imóveis em que vivem pessoas que trabalham no Itatinga, como prostitutas ou exercendo outra função nesta região, tendo como finalidade oferecer moradia e alimentação, porém não possuem quartos destinados ao atendimento de clientes. Quando utilizo o termo casa no decorrer desta dissertação para falar sobre o pensionato, ressalto que é apenas no sentido de um lugar de moradia, ou um lar.

A residência coletiva em que fui recepcionada na primeira incursão a campo, e em que residem nossas alunas do curso de inglês, é administrada por Alice, também conhecida 
carinhosamente como "Mãezinha", travesti que possui uma trajetória de militância nos movimentos de profissionais do sexo e LGBT, porém é apenas uma contratada da dona do pensionato, Juliana, para cuidar das meninas, cozinhando, limpando, disciplinando e cobrando a diária.

Diante do portão do pensionato de Alice e Juliana, as travestis exibem seus corpos em busca de clientes, mas também é neste mesmo local que sentam à sombra das árvores para conversar com as amigas ou fazer as unhas com as diferentes manicures que circulam no bairro. Este imóvel possui uma pequena garagem que abriga geralmente um ou dois cachorros que ficam presos por coleiras. Entrando pela porta, há uma pequena salinha em que as meninas se reúnem para ver televisão e onde Alice dorme. A sala dá acesso de um lado ao um corredor de quartos e um banheiro, e por outro lado tem uma saída para o corredor externo. Este corredor externo possui uma infinidade de plantas, orquídeas em especial, além de cachorros e gatos de várias raças que pertencem às travestis que residem na casa. $\mathrm{O}$ corredor externo abre-se em um quintal que permite o acesso a uma cozinha e ao portão da horta. A cozinha fica geralmente trancada, para que Alice possa trabalhar sossegada na fabricação das refeições diárias, servidas em horários pré-determinados do dia, ao lado de uma dispensa, mais quartos e banheiros. Na horta trabalhada pelas travestis há uma diversidade de hortaliças e animais como galinhas, porcos e cabras, passando a impressão de uma ambiência quase que rural. Ao lado da casa fica um estacionamento que possui um famoso abacateiro, lugar escolhido às vezes para realizar programas.

Os pensionatos possuem regras rígidas de trabalho e convivência pré-estabelecidas, como foi informado pelas moradoras das residências coletivas que visitei. Assim, no pensionato de Alice e Juliana é proibido o uso de certas drogas e o consumo excessivo de álcool, a aplicação de silicone industrial, o uso da violência física na resolução de conflitos, dentre outras regras. O não cumprimento destas regras implica o pagamento de multas. Estas multas podem ser pecuniárias, através da obrigação em realizar algum tipo de tarefa na casa, a exclusão em algum tipo de passeio coletivo previamente organizado, etc. Assim, a multa é da mesma ordem dos "castigos" que as mães aplicam nos filhos, tendo função disciplinar e não propriamente monetária.

O bairro em muitos sentidos é como qualquer outro da região, possuindo serviços básicos como mercados, farmácias, bares, consultório odontológico ou psicológico, uma 
quantidade grande de salões de beleza, lojas de roupas e lingerie especializadas nas vestimentas características do mercado do sexo, etc. Pelas ruas do bairro nota-se que a grande maioria das mulheres e travestis são jovens, sendo que, conversando com alunas e outras residentes do pensionato de Alice e Juliana, sabemos que as moradoras do bairro na sua maior parte vieram de outras cidades ou mesmo outras regiões, havendo sempre a chegada de novas companheiras rapidamente inseridas nas dinâmicas e costumes da casa. O Jardim Itatinga é um local de destino e acolhimento de prostitutas, iniciantes ou pouco mais experientes, pois o bairro é referência nacional em relação ao mercado do sexo, ou seja, possui "nome próprio" (Helene, 2012). Os ônibus passam em pontos apenas na avenida de frente para o bairro e na Rodovia Santos Dumont, com destinos como o centro da cidade, outros bairros periféricos, cidades da região e São Paulo. Portanto, é possível morar em outra cidade e trabalhar no bairro, ou ainda, do bairro ir trabalhar em outros lugares. Porém, observa-se em geral pouca mobilidade das meninas por outras regiões da cidade, dado que o bairro possui um comércio próprio e que o local de trabalho é o mesmo para muitas de moradia.

\section{As pessoas}

Entrei no bairro através da rua lateral ao posto de gasolina, uma rua de terra, esburacada, abrigando vários galpões industriais. Em meio a esta rua, há uma casa com portões sempre fechados, e na parede da fachada possui vários dizeres religiosos. Seria uma igreja, casa de orações? Católica, protestante? A partir da primeira esquina já é possível avistar mulheres se exibindo seminuas nas calçadas das casas para os passantes. (Caderno de Campo, 28/11/2013).

O sexo pago é o elemento ao redor do qual gravitam as relações sociais no Itatinga e está implicado nas diversas interações dadas neste contexto social, porém a vida cotidiana no bairro não se resume as trocas comerciais entre profissionais nas calçadas e clientes em carros. As pessoas assumem múltiplas posições sociais, e a zona possui diversos usos. Dentre a multiplicidade dos frequentadores do Itatinga há clientes, prostitutas, travestis, donos e donas de casa, militantes dos movimentos feministas e do movimento LGBT, 
policiais, comerciantes, ambulantes, babás, assistentes sociais, enfermeiros, médicos, pesquisadores, religiosos e assim por diante.

Arrumamos o projetor e os livros na sala e fomos para o lado de fora aguardar as alunas. Fomos abordadas por dois senhores da Igreja Universal, que nos convidou para uma oração que aconteceria na rua acima, e ao final da conversa um destes homens despediu-se afirmando: "uma palavra pode mudar uma vida".

Quando as meninas chegaram contei o fato a elas. Tatiane afirmou ser descrente quanto aos religiosos que frequentam o bairro, e que recentemente fizera um "boquete" em um "crente" que depois do ocorrido quis dar lição de moral nela. Natalie afirmou que tinha fé. $O$ fato é dentre os vários tipos de frequentadores do bairro estão os religiosos, seja católicos ou protestantes, apesar do lugar não possuir igrejas em si. (Caderno de Campo, 28 de novembro de 2013).

O bairro possui uma diversidade de pequenos comércios e vendedores ambulantes que oferecem uma miríade de mercadorias e serviços, no entanto, no bairro e nas suas proximidades não se observam farmácias nem supermercados. Segundo um funcionário do posto de gasolina, há um risco manter comércios em lugares afastados como o Itatinga, e isto explica a ausência de farmácia, bem como o preço maior que é cobrado pelas mercadorias vendidas no bairro, afinal se trata de uma "zona" localizada na periferia da cidade. Também há profissionais que oferecem serviços de "porta em porta" como as inúmeras manicures que circulam pelo bairro. Dentre estes trabalhadores, existe uma curiosa senhora que oferece serviços mágicos pelas ruas do Itatinga, conhecida como a "Cigana":

Chegando lá fui recepcionada por Jasmine e sentamos em frente à casa. Logo alguém veio avisar que a Cigana se aproximava, esta me abordou e começamos a conversar oferecendo seus serviços "Vejo seus namorados nas cartas e os do passado e do futuro". Falei a ela que já estava resolvida e que não tinha dinheiro naquele momento. Ela perguntou o que eu fazia, dizendo que sou professora de inglês esta perguntou "Hablas espanhol", "yo hablo um poquito", respondi. Ela me disse algumas frases em inglês, perguntei onde era seu acampamento, esta me respondeu que era no Rio de Janeiro, mas que estava hospedada em São Paulo e que vinha eventualmente para o Itatinga, lugar que há 25 anos consegue ter um bom lucro. Pedi que falasse algo em Romani, ela me disse algumas frases, além de falar a palavra para "prostituta" em árabe. A cigana foi embora me desejando muito "axé". (Diário de campo. 29/05/2014).

Cada um desses grupos possuem objetivos específicos em relação ao bairro, sejam 
econômicos, intelectuais ou morais. Portanto, as pessoas em um contexto como este não podem ser descritas como portadoras de características e motivações unívocas, como o senso comum do olhar externo atribuem ao local, e assim, não é um simples "parque temático", pois é ocupado por uma diversidade de indivíduos e grupos profissionais, sendo que estes vivem um cotidiano semelhante em muitos aspectos a qualquer bairro de periferia.

Deste modo, também observa-se em relação às moradoras do Itatinga que se prostituem certa pluralidade de existências advindas do próprio contexto social em que se inserem e que estas produzem. As mulheres que trabalham dia e noite no cotidiano da prostituição também são mães, ao mesmo tempo em que são militantes do movimento feminista ou de prostitutas, seja permanentemente ou eventualmente nos momentos políticos críticos que aparecem ao bairro. Ainda, podem ser religiosas protestantes, católicas, e defender ou não sua posição como profissional do sexo. Assim, tais posições sociais mesmo que contraditórias são realizadas cotidianamente pelas pessoas dentro da especificidade da socialidade do bairro.

O mesmo acontece na ambiência trans do pensionato de Alice, onde travestis e transexuais que se prostituem buscam também um espaço habitável familiar e de afeto, bem como a construção do corpo que o ambiente propicia, seja pelo dinheiro ou pelas técnicas e conhecimentos compartilhados. Neste sentido, a prostituição é uma oportunidade de ascensão corporal ao mesmo tempo em que é o acesso ao olhar e desejo masculino.

De acordo com Strathern (Ingold et al., 2005, p.55), uma pessoa contém uma socialidade generalizada dentro de si, sendo um ser plural ao mesmo tempo em que é singular, deste modo, não é um indivíduo, ou seja, uma unidade indivisível, mas um divíduo. Portanto, segundo esta autora, é necessário concentrar a análise nas relações sociais nas quais os atores são construídos e se constroem. Assim, o conceito de socialidade nos permite expressar as maneiras pelas quais as pessoas estabelecem relações entre si e se recriam a partir delas, sem relegar a personalidade e as relações sociais a um domínio abstrato como no conceito de sociedade (Ingold et Al., 2005, p.47). Ou seja, o conceito de socialidade se opõe ao de socialização ao reconhecer que "[ $[\ldots]$ as pessoas são freqüentemente construídas como lócus plural e compósito das relações que as produzem. A pessoa singular pode ser imaginada como um microcosmo social" (Strathern, 2006, p. 
41). Dentro da perspectiva de Strathern, a pessoa em si existe apenas a partir das relações sociais que estabelece, sendo socialidade e pessoa parte de um mesmo processo.

As travestis da casa, consequentemente, são pessoas singulares, mas que também se constroem nas relações sociais dadas pela própria casa, seja através do compartilhamento de conhecimentos ou obtenção de recursos para transformação corporal.

Do mesmo modo, Denise possui em si esta multiplicidade, este compósito de relações construídos ao longo do tempo de vida, militância e moradia no bairro, sendo uma figura do afeto, e também de autoridade. Ao mesmo tempo em que é defensora do orgulho da profissão, mantém um bom relacionamento com o CEPROMM, ONG católica que visa retirar as mulheres da prostituição, pois foi na igreja que encontrou auxilio quando precisou ajudar diversas amigas travestis no auge da epidemia da AIDS. Segundo a descrição do trabalho de Bahia, Luizari e Faria (2003), ela era a única travesti a tomar a consagração nas missas.

Neste mesmo sentido, da diversidade e multiplicidade das pessoas que residem no bairro, que é visto pelo senso comum como o "parque temático" dos prazeres, o Itatinga também é o local de moradia de uma centena de crianças que são escondidas dentro da creche oferecida pelo CEPROMM, ou ainda, no interior de casas de babás no decorrer do dia e da noite. Assim, Beatriz, que é cabeleireira, profissional do sexo mulher e atuante na luta pelo reconhecimento e respeito da profissão, desabafou sobre o problema recente que enfrentava com o aluguel e as babás das crianças enquanto caminhávamos para o ponto de ônibus. Algumas mulheres são contratadas no Itatinga para "limpar as casas" e "cuidar de criança", e costumam morar também no bairro onde exercem estas funções importantíssimas para o bom andamento das atividades do local. Atrás do salão de Beatriz existe uma casa com duas mulheres que cuidam de crianças, que ficam devidamente reclusas no interior da residência durante o dia. Beatriz começou a fazer programas no salão e por isso suas vizinhas alegaram ser mais justo que ela contribuísse com um montante maior do aluguel, "já que puta ganha mais que faxineira". Ela ficou chateada com o assunto, e Denise a orientou a ser firme afinal "zona não é lugar de criança", mas ela resolveu pagar os 100 reais a mais, pois fazia parte de uma associação que defendia justamente isso, ou seja, creche, melhores condições sociais/trabalhistas para as mulheres que se prostituem. 
Às 18 horas, todos os dias, em uniformes azuis, seguradas pelas mãos de suas mães, as crianças circulam pelo bairro saindo da creche. Certa vez, pude observar que neste horário diferenciado de outros no bairro uma "madrinha" de travesti pode eventualmente se tornar uma "madrinha" de criança, assim como uma mulher que se exibe em frente às casas torna-se uma carinhosa mãe segurando o filho nos braços como vemos no seguinte trecho do diário:

Fechamos à sala de aula e nos reunimos com Beatriz na frente do salão de beleza. Beatriz concordava com as negociações da próxima aula, quando chegaram dois vendedores, um de produtos para salão, outro de trufas de chocolate. As crianças saiam da creche do CEPROMM, um menininho gritou de longe "madrinha", Alice foi em direção ao chamado, mas era com Sonia, a manicure. Dona Sonia faz unhas a muitos anos no Itatinga, abraçou o menininho, Alice também abraçou carinhosamente a criança que a conhecia de longa data e também a interpelava por "madrinha". Por fim, o menino foi embora, suponho com a mãe. (Caderno de campo, 10/10/213).

Natalie recentemente lamentou o desaparecimento de Tatiane, uma aluna do curso de inglês, que, ao ficar grávida de um cliente, foi embora do bairro. Segundo Natalie, "nós" poderíamos cuidar deste bebê, como tantos outros no bairro, pois há recursos financeiros e babás disponíveis para tanto. No trecho do diário a seguir recordo a penúltima vez que conversei com Tatiane quando a avistei andando pelas ruas do Itatinga:

Pelas 5 horas o movimento já aumentava pelo bairro, quando avistamos Tatiane. Ela se juntou a nós e contou que ficara grávida e mudara da casa de Juliana, morando de graça com outras amigas estando aliviada por não ter que pagar as diárias de 50 reais. A gravidez é de um cliente, porém nada revelara a ele, por medo de sofrer e perder o dinheiro que ganha com este homem já que se trata de um cliente habitual. Ela pensara em fazer um aborto, porém Juliana afirmou que ajudaria a cuidar. Segundo Tatiane ela parou de "cheirar", porém continua a fumar maconha, não bebe mais, porém nunca bebeu bebida forte mesmo, fuma poucos cigarros por dia. Contou-nos que sua mãe fumara "pedra" quando estava grávida, e que seu pai é professor de história e português, sendo que ela estudou em colégio interno protestante até os 18 anos. Disse estar ansiosa para o retorno das aulas e ficou muito feliz em saber que será para o próximo dia 18. (Caderno de campo, 06 de Janeiro de 2014).

A partir deste dia, Tatiane não apareceu mais nas aulas. Eu a visitei na casa em que permaneceu por certo tempo para lhe entregar materiais escolares e livros, uma vez que se tratava de uma boa aluna de inglês. Não se sabe ao certo porque Tatiane deixou o bairro, o 
fato é que não se sentia à vontade com a profissão e presenciamos várias vezes sua indisposição de trabalhar tendo "Mãezinha" proposto a ela que a auxiliasse com os serviços domésticos da casa em vez de sair às ruas com as colegas. Uma colega do pensionato levantou a hipótese que Tatiane tinha dificuldades em seguir as regras, principalmente aquelas relativa ao uso de álcool e drogas.

Portanto, uma multiplicidade de papéis e posições faz parte do cotidiano do bairro, bem como as pessoas são forjadas, criadas dentro das relações nas diversas trajetórias de vida, trabalho e militância política. O bairro, em si, é múltiplo. Além de lócus da prostituição também é espaço de "fazer política" para setores do movimento feminista, LGBT e assim por diante; é um lugar de estabelecer parentescos, redes de auxilio, objetos de pesquisa; é um espaço privilegiado de conversão religiosa; contexto lucrativo para comércio ambulante e assim por diante. No Capítulo 2, percorrendo as redes que se conectam ao Itatinga, analisaremos os diferentes circuitos acadêmicos, políticos e culturais que atravessam o bairro.

\section{O CEPROMM e a Associação Mulheres Guerreiras}

Eu sou uma garota de programa, pode me identificar em todos os lugares? Eu sou prostituta. Ser prostituta é o que me define. Eu sou uma profissional do sexo. Você sabe o que é melhor pra mim? Eu sou "puta", eu sou "puta". A minha presença de te incomoda? E sou mulher de vida livre. A gente faz a diferença! Eu sofro preconceito. ("Eu sou feliz sendo prostituta", 2013.2 Disponível em: http://www.youtube.com/watch?v=YT5rQTug040).

Como descrevi anteriormente, O CEPROMM (Centro de Promoção da Mulher Marginalizada) e a Associação Mulheres Guerreiras foram as entidades que nos recepcionaram através de suas representantes em campo, e por meio da parceria entre estas foi possível a realização do projeto do curso de inglês. Aliás, tanto a ONG quanto a Associação já atuaram em conjunto na realização de diversos eventos e projetos, muita das vezes através da mediação de Denise e do suporte material, especialmente no oferecimento do espaço físico, do CEPROMM. Porém, os dois grupos possuem visões opostas sobre a 
prostituição e os efeitos sociais desta prática econômica na vida de mulheres e travestis. Como veremos a ONG, como já esta sugerido em seu nome, busca retirar a mulher da condição de prostituta oferecendo suporte para que outras alternativas de vida sejam vislumbradas por estas mulheres, sendo a prostituição considerada uma atividade degradante, configurando uma exploração brutal fruto de uma sociedade profundamente machista. A Associação, por sua vez, parte do pressuposto de que as profissionais do sexo devem lutar por direitos e reconhecimento da sua profissão, sendo que as negativas moralistas de escolha autônoma desta trajetória profissional acabam por desmobilizar e deslegitimar as reivindicações por melhores condições de trabalho e combate ao estigma e preconceito. Deste modo, ONG e Associação se localizam em polos opostos de uma disputa política de qual seria o lugar social da prostituição, sendo esta uma controvérsia que atravessa diversos espaços da sociedade, dentre as quais os diferentes segmentos dos movimentos feministas e LGBT, a elaboração e implementação de políticas públicas, o debate político/ideológico entre parlamentares representantes de diferentes grupos sociais e assim por diante. Consequentemente, a suposta felicidade de uma profissional do sexo, num cartaz que talvez ficasse esquecido numa parede qualquer de uma Unidade Básica de Saúde (UBS) com clientela oriunda da prostituição, tornou-se o centro de um debate acionada por distintos segmentos sociais e políticos.

A frase que iniciou a discussão sobre este tópico é uma transcrição de um vídeo criado para promover a campanha do Ministério da Saúde para prevenção de DST/AIDS entre profissionais do sexo. $\mathrm{O}$ vídeo e os cartazes foram produzidos e pensados por um grupo de prostitutas em uma oficina de comunicação sobre saúde em João Pessoa (PB) no mês de Março de 2013, e tinha como objetivo, além da mensagem de prevenção, reduzir o estigma da prostituição associada à infecção pelo HIV e AIDS. Os cartazes também traziam frases como "não aceitar as pessoas da forma como elas são é uma violência", "um beijo para você que usa camisinha e se protege das DST's, AIDS e hepatites virais" e "o sonho maior é que a sociedade nos veja como cidadãs", e por fim, em um dos vídeos uma prostituta relatava que "sonhei que sou respeitada, que sou uma flor, uma rosa sem espinhos". O tema da campanha era "Sem vergonha de usar camisinha" e celebrava o Dia Internacional das Prostitutas, comemorado em 2 de junho.

O vídeo foi retirado do site do Ministério da Saúde, bem como vários cartazes que 
faziam parte da campanha e que continha a frase "Eu sou feliz sendo prostituta". Sendo que, o ministro da Saúde, Alexandre Padilha, demitiu Dirceu Greco, o diretor do Departamento de Vigilância, Prevenção e Controle das Doenças Sexualmente Transmissíveis, Síndrome da Imunodeficiência Adquirida e Hepatites Virais do Ministério, após divulgação de campanha. O Ministério da Saúde informou, por meio de sua assessoria de imprensa, que a demissão acontecera porque o departamento vinculou a campanha sem a autorização dos responsáveis pela Comunicação Social. Padilha afirmou em seu microblog twitter:

Não autorizei que a mensagem "sou prostituta sou feliz" seja do Ministério da Saúde. Movimentos ou indivíduos podem fazê-lo, nos seus blogs, sites, perfis e respeito-os. A decisão de retirar material não autorizado foi anterior a qualquer manifestação contra ou favor. Pelo simples fato: não eram autorizadas.

Antes da proibição da campanha, a bancada religiosa conservadora manifestou-se contra ela. O deputado Marco Feliciano (PSC-SP), na época presidente da Comissão de Direitos Humanos e Minorias da Câmara, pediu esclarecimentos ao Ministério da Saúde sobre a campanha. Feliciano aproveitou o momento de apresentação do requerimento do deputado Costa Ferreira (PSC-MA), que solicitava a realização de audiência pública para debater políticas que visam à valorização e a proteção da família, para incluir nele um pedido de informações ao Ministério da Saúde.

- Já vou pedir à mesa para incluir nesta pauta um requerimento de informação ao Ministério da Saúde sobre essa famigerada campanha disse Feliciano.

O deputado João Campos (PSDB-GO), da bancada evangélica também se manifestou:

- Eu estou imaginando aqui os títulos das próximas campanhas: "sou adúltero e sou feliz", "sou incestuoso, sigam-me", "sou polígamo, me acompanhem", "sou pedófilo, observem-me, sou feliz, estou realizado" - afirmou Campos.

- Que isso não aconteça - respondeu Feliciano.

- Ainda que a prática da prostituição não seja crime, o que o governo faz através de uma campanha midiática, publicitária é uma apologia ao crime, apologia à prostituição - acrescentou o deputado Marcos Rogério (PDT-RO). (Retirado do portal G1 da Globo http://g1.globo.com/cienciae-saude/noticia/2013/06/diretor-responsavel-por-campanha-sou-felizsendo-prostituta-e-demitido.html)

A presidente da Associação das Prostitutas de Minas Gerais (Aprosmig), Cida 
Vieira, afirmou em entrevista que a campanha leva a uma discussão constantemente evitada, a da legalização da prostituição. O reconhecimento da profissão é a bandeira dos movimentos de profissionais do sexo pelo Brasil, inclusive da Aprosmig, que Cida Viera representa ${ }^{6}$. A decisão do Ministério da saúde motivou uma série de notas de repúdio de associações, movimentos sociais, secretarias estaduais e núcleos de pesquisa sobre o tema nas universidades, publicadas nas redes sociais e no website de Gabriela Leite, que estava à frente na época da Rede Nacional de Prostitutas ${ }^{7}$.

Como bem referiu Fernanda Benvenutty, enfermeira e militante transexual brasileira, em evento sobre "gestão de riscos", promovido recentemente pelo Departamento de AIDS do Ministério da Saúde (entre 3 e 4 de junho): ao dizer que são felizes, sendo prostitutas, o que essas mulheres estão afirmando é que, APESAR de uma cultura machista, APESAR de uma sociedade que não as respeita, que as discrimina e que insiste em invisibilizá-las, apesar de um governo que não respeita seu verbo e suas práticas, APESAR DE TUDO elas são felizes! E esse direito humano à felicidade não lhes pode ser negado. (Nota pública da APPS, Fórum LGBT-PE, Instituto PAPAI, CMC, Gema, LabEshu e Gepcol, 7 de Junho de 2002).

É a higienização da vida. [...] com essa forma de agir, o governo se coloca na arrogante posição de só permitir às prostitutas aparecer como vítimas ou vetores, portanto, sujeito sem voz, que só tem o direito de ser resgatado pelo Estado provedor do único elemento "pegue a sua camisinha na unidade de saúde" que irá salvá-las da AIDS. [...]. A atitude do governo também revela a tentativa de alimentar à estrutura moral da família a qualquer custo, numa covarde cumplicidade com um discurso que relegam prostitutas e outros segmentos "inconvenientes" à margem de um modelo de sociedade. [...] Ao se pronunciar logo de início contra o texto "Sou feliz sendo prostituta", demonstra também a arrogância de não acreditar que uma prostituta pode ser feliz e o medo de que nós expressemos um desejo de felicidade que vai contra esse modelo. (Nota da Rede Brasileira de prostitutas, em 7 de Junho de 2002).

A reação contra a campanha não partiu apenas da bancada conservadora no Congresso Nacional, mas poderia ser visualizada também nos inúmeros comentários nas notícias na internet e nas redes sociais, seja dos segmentos religiosos, dos movimentos feministas ou pessoas em geral que se opõem à ideia que exista dignidade na profissão.

\footnotetext{
${ }^{6}$ Ver http://g1.globo.com/minas-gerais/noticia/2013/06/sou-feliz-na-profissao-diz-presidente-da-associacaode-prostitutas-de-mg.html.

${ }^{7}$ Associação Pernambucana das Profisssionais do Sexo - APPS, Núcleo de Estudos da Prostituição em Porto Alegre, Rio Grande do Sul. Associação de Prostitutas do Estado do Pará (Gempac), Associação Pernambucana de Profissionais do Sexo (APPS), Fórum LGBT de Pernambuco, Instituto PAPAI, Centro das Mulheres do Cabo e dos Núcleos de Pesquisa da UFPE (Gema, LabEshu e Gepcol), etc.
} 
Partindo da controvérsia apresentada aqui, discutimos a seguir questões relativas à posição social das prostitutas mobilizadas pela campanha proibida pelo Ministério da saúde. O tema escolhido neste tópico foi motivado por uma "experiência etnográfica" de estranhamento nas primeiras incursões a campo no Itatinga, na qual não sabia o que observar exatamente nas visitas que fiz ao bairro, e onde tudo parecia igualmente relevante e interessante. Sendo assim, compreendi as nuances da questão levantada, "a felicidade das prostitutas", através dessa "experiência etnográfica", mas também acessando recursos documentais como reportagens, vídeos, panfletos, notas de entidades e órgãos governamentais que recuperavam os termos da controvérsia.

O delinear desta controvérsia, portanto, foi inspirado em experiências em campo, no Itatinga, e numa mesa de debate sobre o projeto de Lei de Jean Willys, conhecido como Lei Gabriela Leite, realizada pela coletivo Feminista do curso de Relações Internacionais da USP, na qual debateram Bethânia da Associação Mulheres Guerreiras e Cleone da Pastoral e Marcha Mundial das Mulheres.

a) "Isabelzinha, agora você já está entendendo melhor o que é prostituição"

Deste modo, se a controvérsia é uma tipo de drama social que revela os conflitos existentes em relação as definições da realidade social, a felicidade das prostitutas era uma controvérsia que mobilizava diferentes segmentos da sociedade e que levantava uma questão crucial que uma "experiência etnográfica" em uma visita a campo me despertou sobre o assunto se configurando como um momento fundante e imprevisto de estranhamento.

Como sabemos, no momento que Letizia Patriarca e eu tivemos a ideia de propor um formato para o curso de Inglês comunitário idealizado por Bethânia, em Julho de 2013, Dona Denise nos deu muito apoio. Na busca por uma sala, ela se propôs a conversar com o CEPROMM, explicitando que era melhor que ela mesma conversasse, pois havia uma relação entre ela e o centro católico de longa data.

Perguntei se as pessoas não se sentiriam constrangidas em assistir aulas no Centro, ela me disse que não e explicou a diferença entre a posição da associação de prostitutas que ela fazia parte e a posição da ONG católica. A diferença, segundo ela, era que o centro 
estava lá para ajudar a mulher que acredita estar perdida, em uma situação de exploração e vulnerabilidade. Por outro lado, Denise e o movimento de prostitutas local que tem como matriz Gabriela Leite, acredita na autonomia das profissionais do sexo na escolha de sua profissão e estilo de vida, e defende a possibilidade de orgulho de sua profissão, bem como a profissionalização. No final do encontro, ela se despediu de mim e disse: "Isabelzinha, agora você já está entendendo melhor o que é prostituição", o que provocou certo estranhamento: eu havia entendido exatamente o que, para tornar essa conversa significativa para minha interlocutora?

Um dia antes desta conversa com Dona Denise, na qual supostamente comecei a entender melhor aquele contexto, fui a uma mesa organizada pelo "Cine Pagu", do Núcleo de estudos de gênero Pagu da Unicamp, para discussão do filme Um beijo para Gabriela, que tinha como convidada especial justamente Gabriela Leite. $\mathrm{O}$ tom do debate era de preparação política para a ofensiva cada vez maior dos setores conservadores em relação às políticas públicas direcionadas a homossexuais, profissionais do sexo e mulheres. Gabriela Leite se mostrava muito aborrecida com o episódio que acabara de acontecer no Ministério da Saúde. Falou ainda sobre a importância para as profissionais do sexo de assumir a identidade de "puta" para reivindicar direitos trabalhistas e sociais. Neste sentido, disse ainda que as "travestis" não se unem ao movimento, pois não se vêem como "puta", se vêem como coitadas inseridas na única profissão que supostamente podem exercer, pois afirmam que se pudessem trabalhariam em outras profissões. Ainda segundo Gabriela, contudo, as mulheres como prostitutas não teriam desculpas moralistas como as travestis. Mal sabia ela, pensei eu, que nossa interlocutora, Dona Denise, é uma travesti militante pelos direitos das prostitutas. Gabriela, por fim, respondeu uma série de questões e provocou uma diversidade de debates que mobilizavam pessoas da plateia e da mesa. Uma dessas pessoas foi Bethânia, prostituta do Itatinga. Bethânia expressou em sua fala a admiração por Gabriela Leite, que a fez mudar de ideia em relação à prostituição e seu próprio papel político, ainda falou do orgulho em ser prostituta, que se sente feliz na profissão, pois a permitiu ter casa, carro e pagar faculdade para as filhas.

O projeto de lei de Jean Willys, por sua vez, também participa da mesma controvérsia acerca da prostituição. No projeto, se regularizam as casas de prostituição e é oferecida aposentadoria especial aos profissionais do sexo, uma reivindicação dos 
movimentos de prostitutas. Segundo o deputado, o projeto combate à exploração, já que estabelece um valor máximo que a casa pode cobrar, e também a exploração de crianças e adolescentes, pois favorece a fiscalização das condições de trabalho. Porém, o projeto enfrenta oposição, tanto de setores religiosos e conservadores, quanto de segmentos do feminismo radical, que enxergam a prostituição como forma de exploração da mulher em uma sociedade atravessada por assimetrias de gênero.

Este debate acerca da autonomia e agência das mulheres profissionais do sexo arregimenta diversas posições no movimento feminista em termos políticos e teóricos, situando de um lado segmentos que defendem que a prostituição e também a pornografia são formas violentas de exploração das mulheres, como Catherine MacKinnon $(1982,1989)$ e de outro lado, teóricas como Gayle Rubin (2003) que advogam ser necessária a criação de leis que regularizam a profissão de modo a oferecer dignidade às pessoas que trabalham com sexo.

\section{b) Qual o lugar da prostituição no feminismo?}

Sou feminista radical e abolicionista, acredito que a mesa é leviana, pois não tem ninguém pela abolição. A prostituição não é sexo consentido, é uma forma brutal de estupro. (Militante do comitê para abolição da prostituição, no debate sobre o Projeto de Lei Gabriela Leite na USP, em 16/05/2014).

A fala acima foi feita por uma militante do movimento feminista, do Comitê para Abolição da Prostituição, na ocasião de uma mesa de debate sobre o projeto de Jean Willys de regulamentação da prostituição, na qual participaram Bethânia, da Associação Mulheres Guerreiras do Itatinga e da Rede Nacional das Prostitutas, e Cleone, ex-prostituta, da pastoral e Marcha Mundial das Mulheres, que atua em projetos sociais que tem como alvo as mulheres da Luz. A mesa em questão foi organizada pelo Coletivo Feminista do curso de Relações Internacionais da USP e teria como objetivo colocar frente a frente os prós e contras do referido projeto de lei, deste modo, quem o defenderia seria Bethânia, e quem colocariam argumentos contrários seria Cleone.

Ser feminista radical é uma posição, e uma oposição, muito especifica no movimento feminista que teve dentre suas representantes na teoria feminista Catherine 
MacKinnon. O feminismo radical é uma corrente ideológica dentro do feminismo que afirma ser o sexismo a origem de toda opressão, sendo uma teoria sobre o patriarcado, que é descrito como um sistema de poder que organiza a sociedade na opressão das mulheres pela dominação masculina.

Catherine MacKinnon possui uma trajetória de militância teórica e jurídica contra a pornografia e a prostituição. Sendo advogada, seu caso mais conhecido foi o de "Garganta Profunda", no qual a atriz principal do filme processou seu ex-marido e diretor acusandoo de obrigá-la a fazer o filme, sendo vítima de violência doméstica e sexual.

Abolir a prostituição pode significar a criminalização da prática, e essa era a proposta da militante em questão ao citar os países que aboliram o sexo pago. Por outro lado, mobilizar o debate sobre a abolição é conjecturar sobre uma sociedade futura na qual não exista a prostituição em si. O primeiro é uma posição jurídica e política complicada, pois facilitaria a exploração e a violência estando o sexo pago na ilegalidade, afinal a proibição não é garantia efetiva de abolição da prática. A segunda interpretação estaria no nível da utopia, na qual o oferecimento do serviço sexual mediante pagamento não existiria, pois a própria estrutura social oferecia impedimentos concretos ao sexo mediado pelo dinheiro. Cleone parecia partilhar desta posição, ao afirmar-se abolicionista, reconhecia a existência concreta das dificuldades diárias das profissionais do sexo, pontuando a necessidade de uma legislação mais abrangente que a proposta de Jean Willys e que levasse em conta todas as posições possíveis das mulheres reais que estão na prostituição, seja em São Paulo ou em Pernambuco.

Numa sociedade sem prostituição, as pessoas não vislumbrariam o sexo pago como possibilidade econômica diante da disponibilidade de condições educacionais e de empregabilidade adequadas. Os clientes, por sua vez, não procurariam o serviço sexual, pois não haveria oferta disponível. Há alguns complicadores nesta formulação como a possibilidade de carreiras satisfatórias economicamente no serviço sexual e a prática da prostituição como uma expressão possível do desejo.

Diante da agressividade da intervenção das feministas abolicionistas à mesa resolvi pedir a palavra e questionar nossas palestrantes sobre as possibilidades políticas e jurídicas para enfrentar a exploração sexual e a violência, seja de clientes ou estatal. Afinal, exemplifiquei a Cleone e Bethânia que, sendo professora, tenho uma legislação, um 
estatuto, que permite que meu local de trabalho seja fiscalizado de modo que não eu sofra na medida do possível uma exploração desmedida por parte de meus contratantes. No limite todos os trabalhadores em empregos formais têm como amparo a CLT, a Consolidação das Leis do Trabalho. Então, quais as possibilidades políticas que minhas interlocutoras, cada qual na sua perspectiva, vislumbravam como eficazes para combater o trabalho sexual degradante, a escravidão, e a exploração sexual de menores, e por fim, a violência? Pontuei que abolir a prostituição era uma perspectiva louvável, mas o que fazer numa realidade onde esta existe efetivamente, como garantir condições de vidas adequadas a estas profissionais? Quanto à violência exemplifiquei aos presentes que a condição do bairro Itatinga como estigmatizado motivou uma intervenção e "toque de recolher" da polícia em Outubro de 2013 instigados pelo assassinato de um policial, ocorrendo uma série de violações dos direitos humanos e civis de moradoras e comerciantes.

Bethânia reiterou a importância do Projeto de Lei Gabriela Leite que permitiria a fiscalização efetiva dos locais de trabalho das prostitutas coibindo toda e qualquer exploração. Quanto à fiscalização em relação à exploração sexual de menores, ela pontuou que esta é atualmente de responsabilidade dos conselhos tutelares, o que não impede que meninas menores de idade procurem o Itatinga para oferecer este tipo de serviço, mas que estas crianças e adolescentes são geralmente retiradas do bairro pelas próprias profissionais adultas ou pela própria intervenção do conselho. Segundo ela, costuma brincar "por que alguém pegaria franguinhos se tem a possibilidade de comer Fri-boi?”, mas que após um tempo, já maiores de idade, as meninas retornam satirizando "viu, tia, estou aqui de novo". Esta fala de Bethânia, comparando serviço sexual ao ato de comer carne, provocou certo burburinho da plateia, mas Bethânia argumentou que era uma brincadeira, afinal ela "não vende seu corpo, apenas o empresta por alguns minutos oferecendo um serviço" como qualquer trabalhador no capitalismo que vende sua "força de trabalho", como aprendeu com seus amigos sindicalistas. Bethânia, por fim, observou que é preciso garantir direitos para a geração que está chegando à prostituição, mas também para as mais velhas, afinal o projeto de lei em questão garante aposentadoria especial aos profissionais do sexo.

Retirou de sua pasta uma cópia de uma reportagem sobre a reação das prostitutas a invasão do Jardim Itatinga por policiais em Outubro de 2013, quando estas ocuparam a Rodovia Santos Dumont a fim de negociar a normalização da situação. Arregalavam-se os 
olhos de alguns na plateia, enquanto a reportagem circulava pelas mãos curiosas dos ouvintes. "Somos organizadas", disse Bethânia, "temos uma associação", sendo este o caminho para se lutar contra o estigma que segundo ela não somente vitimizou apenas o Itatinga na época, mas outros bairros do entorno localizados na periferia de Campinas.

Cleone, por sua vez, confirmou a necessidade de uma legislação que regulasse as relações trabalhistas das prostitutas, mas a proposta de Jean Willys não seria realista quanto aos diferentes contextos da prostituição no Brasil, pois o Itatinga obviamente é diferente da Luz e consequentemente de regiões afastadas do nordeste, norte e centro-oeste do país. No nordeste, por exemplo, existiria segundo ela uma cultura machista e violenta muito mais forte que em São Paulo, e uma legislação que favorece apenas os proprietários de casa não teria efeitos positivos nestas localidades. De acordo com Cleone, é necessário elaborar uma estratégia de ação política e jurídica em conformidade com todas as mulheres em “situação de prostituição", sendo necessário dialogar com esta diversidade de profissionais a fim de elaborar uma proposta comum. Disse ainda ser abolicionista também, mas que reconhece a necessidade de atuação num presente na qual a prostituição é um fato. Porém, esta aceitação de si como profissional do sexo, como de Gabriela e Bethânia, não é a realidade da maioria das profissionais que sentem o peso e a vergonha de estarem nesta “situação" conforme Cleone.

Terminando as discussões, comentei com uma das organizadoras que havia me sentido incomodada, mas não pela agressividade que caminhou o debate - pois este era de fato um espaço de discussão política, que se diferencia da tônica que estamos acostumados na academia. O que faltou ao debate, sugeri, foi a presença de outros profissionais do sexo além de mulheres, pois a escolha apenas destas polarizou e restringiu o debate nos limites do feminismo e que o referido projeto de lei também se direcionava aos profissionais travestis e transexuais, bem como aos homens que se prostituem.

De acordo com a perspectiva de Gayle Rubin (2003), o feminismo é uma fonte interessante de pensamentos sobre o sexo, porém é uma teoria circunscrita à "opressão de gênero". Portanto, não é uma teoria da opressão sexual, afinal é necessário distinguir gênero e desejo erótico. Assim, Rubin argumenta ser errônea a afirmação de MacKinnon que "a sexualidade é para o feminismo o que o trabalho é para o Marxismo", pois nem o marxismo nem o feminismo seriam capazes de oferecer explicações para toda e qualquer 
realidade (Rubin, 2003, p.43). Assim como o gênero, a sexualidade também é política, e deste modo, seria preciso "reconhecer as dimensões políticas da vida erótica" (Rubin, 2003, p.45).

Rubin (2003, p.35) pontua que a relação entre feminismo e sexo é complexa, havendo duas correntes que se opõem. A primeira tendência denuncia as restrições ao comportamento sexual das mulheres, enquanto a segunda aponta que a liberação sexual feminina seria uma mera extensão do privilégio masculino. As abolicionistas que nos deparamos na mesa de discussão do projeto Gabriela Leite, neste sentido, compartilham a posição desta segunda vertente.

O movimento anti-pornografia contemporâneo ao trabalho de Rubin também possuía posição semelhante condenando além desta todas as variantes da expressão sexual como anti-feminista, seja a prostituição, a transexualidade, o sadomasoquismo, dentre outras, sendo estes considerados desvios falocêntricos (Rubin, 2003, p.36). Estas feministas utilizam como tática retórica, conforme a autora, a generalização destas expressões sexuais como degradantes por meio dos piores exemplos disponíveis, deturpando a sexualidade humana nas suas várias formas. Por exemplo, esta ideologia feminista generaliza toda e qualquer produção pornográfica como sadomasoquista, acusando-as como influenciadoras do estupro. Porém, esta é uma associação deslocada, pois não há evidência concreta que os praticantes de $\mathrm{S} / \mathrm{M}$ cometem em grande número crimes sexuais.

Portanto, de acordo com Rubin (2003, p.36) esta tradição culpabiliza grupos específicos, e não denuncia a generalização do sexismo na sociedade das quais estas pessoas fazem parte, e que está presente em instituições como família, religião, educação e etc. Este discurso feminista reitera, portanto, uma moral sexual conservadora que faz historicamente oposição a pornografia, prostituição e homossexualidade.

Nesse debate, Rubin observa que "o sedimento legal é mais espesso - e a legislação sexual tem sua potência máxima - em áreas que envolvem obscenidade, dinheiro, menores e homossexualidade" (2003, p.23). Por exemplo, a legislação sexual está muito presente na regulação entre sexo e dinheiro, o que torna os trabalhadores do sexo vulneráveis a exploração e as más condições de trabalho. Assim, "caso o comércio sexual fosse legal, os trabalhadores do sexo seriam mais aptos a organizar e lutar por melhores ordenamentos, 
melhores condições, maior controle e menos estigma" (idem).

Portanto, existe uma batalha política direcionada ao sexo, com conflitos e disputas ideológicas e por territórios específicos, resultando na regulação legal das condutas sexuais. O ápice do conflito sexual é o pânico moral que se caracteriza pela entrada do sexo no palco central da política, e nesta lógica, atitudes outrora difusas são organizadas em uma ação política conjunta demandando uma mudança social (Rubin, 2003, p.29), como parece ser o caso aqui em análise.

\section{c) A "campanha" proibida e a "experiência etnográfica".}

O modelo adotado pelo Ministério da Saúde na construção inicial da campanha que acabou por ser proibida, feito em uma oficina que agregava representantes das associações de profissionais do sexo, adotava o princípio da "prevenção dialogada", que tem sido até recentemente um modelo de ação comum nas políticas públicas de prevenção de DST/AIDS. A abordagem da prevenção dialogada é fruto das críticas aos outros modelos de ação em relação a AIDS, que não levavam em conta os contextos sociais específicos das diferentes populações alvo (Pelúcio, p.26, 2007).

Tendo isto em vista, a experiência etnográfica, que aconteceu quando Dona Denise afirmou que eu já começara a compreender um pouquinho de prostituição, ao me apresentar a "controvérsia" que as cerca em relação à autonomia ou a vulnerabilidade da pessoa prostituída, me levou a refletir sobre o contexto macro das políticas públicas direcionadas a esta população, bem como as diferentes posições dos grupos envolvidos. De um lado, temos a resiliência na aplicação de políticas públicas as sexualidades dissidentes imposta recentemente por grupos políticos conservadores, o que é contraditório com a orientação nos órgãos governamentais de incluir estas populações, especialmente os setores militantes, na elaboração e aplicação destes projetos. Por outro lado, para outros setores, incluindo segmentos do feminismo e ONGs, a "felicidade" proposta pelos movimentos sociais de prostitutas é incompreensível, apenas as reconhecendo como "sujeitos" em termos de vulnerabilidade como podemos observar em relação à mesa sobre o Projeto de Lei Gabriela Leite e a interpelação abolicionista correspondente. Por fim, a mensagem dos movimentos, em contraposição à do ministro, é que não basta incluí-las apenas em termos de simples 
"mensagens de prevenção" descontextualizadas, mas é necessário incluir seu universo social como um todo, reconhecendo suas subjetividades e problemas em relação ao preconceito e a precariedade das suas condições de trabalho.

A prostituição também é uma problemática para o movimento LGBT, especialmente para as pessoas trans. Como veremos adiante, a categoria travesti é associada diretamente no senso comum à prostituição e à marginalidade, o que motiva a escolha de outras categorias por muitas pessoas para se descrever como transexual, transgênero ou até mesmo trans. Há um discurso de que a prostituição tem sido a profissão da grande maioria das travestis pela fala de oportunidades profissionais alternativas em razão da transfobia generalizada no mercado de trabalho e, ainda, a baixa escolaridade desta população que foi excluída do acesso à educação frente a um ambiente escolar hostil e homofóbico. Como contraponto a esta argumentação, existem discursos concorrentes de que, apesar das dificuldades existentes e da pequena margem de oportunidades, as travestis que são profissionais do sexo podem ter feito esta escolha profissional e que é necessário lutar pelo respeito tanto por serem trans quanto por se prostituir. No fim, é importante observar que nossa interlocutora na Associação é uma travesti. 


\section{CAPÍTULO 2. Como se faz e se vive a política desde das margens}

Podemos imaginar uma minoria a que seja tratada como marginal ou um grupo marginal que queria ter a consistência subjetiva de uma minoria, por exemplo. E aí teremos um conjunto dialético entre minoria e marginalidade. (Guattarri, 1996, p.122).

\section{Redes, trajetos e circuitos. Do Itatinga para outros lugares}

Agier argumenta $(2011$, p.32) que a cidade bis é a cidade produzida pelo antropólogo ao observar as práticas e representações dos citadinos, bem como as relações que estabelecem entre si. Portanto, ao fazer etnografia o autor possui uma série de dados que precisam se tornar inteligíveis tendo como resultado interpretações coerentes sobre a cidade e sua complexidade. Seguindo esta perspectiva, Agier (2011, p.33) propõe analisar os saberes (a cidade dos antropólogos) os espaços (a cidade em processo) e as situações (a cidade em movimento).

Partindo deste ponto de vista analítica, este trabalho visa descrever um território específico da cidade, que possui uma sociabilidade caracterizada pelo imaginário citadino do espelhamento invertido dos valores e regramentos da normalidade, pois é reivindicado como lugar das margens por certos atores que desejam afastar o que consideram como práticas anti-sociais como a prostituição e a nudez pública. Isto explica o planejamento e construção histórica de um local especialmente destinada à prostituição, acionado nos discursos da população em contextos de conflito como no caso do Bosque, possuindo o sentido evidente de certa expectativa de que se enviem os supostamente desregrados a esta região. Porém, como vemos em vários episódios narrados nesta dissertação, o Itatinga não é absolutamente um lugar da ausência de regras, mas regulamento por um código de comportamentos estrito. Do mesmo modo, o bairro também não é na sua prática isolado do ponto de vista cultural, econômico e político do restante da cidade, apesar de estar localizado fisicamente na periferia fronteiriça desta.

Portanto, é necessária a reconstrução desta cidade analítica, ou bis, descrever as redes que conectam este espaço social, supostamente atravessado por um cordão de isolamento, com outros contextos sociais característicos da sociabilidade cultural e política 
de Campinas e região. Afinal, sendo a cidade conforme Agier (2011, p.37) uma multitude sem totalidade, ou seja, demasiadamente grande para o antropólogo, dada as práticas microbianas singulares e plurais dos citadinos, esta é uma heterogeneidade que o pesquisador deve compreender em termos de sua complexidade.

A antropologia urbana deve partir do pressuposto que a cidade é uma cidade vivida, uma cidade sentida e uma cidade em processo. Assim, o antropólogo observa essa vivência citadina através das situações que efetivamente etnografa e a partir delas compreende os processos sociais mais amplos nas quais estas estão inseridas. Deste modo, o pesquisador deve ver a cidade a partir da ótica dos citadinos, olhando por cima dos ombros destes, identificando o que produz a cidade bem como as interpretações práticas deste fazer (Agier, 2011, p.38).

Assim sendo, podemos afirmar que a cidade possui regimes próprios de urbanidade. Metodologicamente, estes regimes são inteligíveis por meio da observação de espaços, situações e lugares que compõem a citadinidade. Mas, qual seria o lugar na cidade de espaços sociais segregados e estigmatizados como o Itatinga? Agier (2011, p.38) propõe questionar que vida social emerge dos lugares mais precários da cidade: nas margens e nos espaços extraterritoriais. Como se faz a cidade a partir das margens urbanas (bairros populares, invasões, acampamento de refugiados e etc.)? Com a finalidade de responder a estes questionamentos, o autor conclui que são observáveis em tais espaços marginais sentidos e relações de uma cidade nua, sendo estas simples aglomerações densas e heterogêneas, que se fixa e se transforma sem projeto inicial de cidade e que, portanto, uma antropologia das margens é necessariamente uma antropologia das margens do Estado, e vice versa. Assim, refletir acerca das margens é estudar o Ban lieu, um lugar do afastamento, do banido, cujo distanciamento e confinamento político e territorial permite todas as dominações e exclusões, sejam elas econômicas culturais ou raciais. Portanto, estudar esta "não-cidade", que a própria cidade e o Estado imaginam deste modo, é fundamental para compreender as próprias dinâmicas do urbano. Pois, apesar de ser visto como de fora este território do banimento faz parte do conjunto social da cidade, incluindose numa lógica de uma região de universidades e mobilizada por movimentos sociais no caso deste estudo.

Porém, como na prática traçar este quadro social ampliado através de uma 
metodologia restrita ao olhar imediato do pesquisado como a Etnografia? Agier (2011, p.59) propõe que o conhecimento da antropologia urbana emerge da observação de situações etnográficas específicas que apresentam a montagem de sequências da vida urbana, enfim, a antropologia se ocupa do nível microssocial. Portanto, o autor afirma que esse é um conhecimento parcial, alcançando a totalidade da cidade apenas por intermédio de procedimentos específico tais como a metonímia (a cidade é a rua), a metáfora (a cidade é uma selva ou um mosaico) e, por fim, as comparações e a interdisciplinaridade. Seguindo esta perspectiva, aparece uma questão metodológica central, ou seja, como passar do trabalho de campo, restrito ao microssocial e pautado em um conhecimento intersubjetivo individual, para a totalidade da cidade, que por definição não se pode apreender em termos empíricos? No caso de nosso objeto estudo, como se conecta a outros espaços e esferas da vida social da cidade uma vizinhança distante simbólica e geograficamente do resto da cidade, ou ainda, da "normalidade" campineira.

Assim, Agier oferece um guia de pesquisa antropológica na cidade (2011, p. 61), emprestando conceitos e categorias da Escola de Chicago e de Manchester tais como as ideias de situação, região e rede, o que fornece um vocabulário de antropologia urbana que permite a intermediação metodológica do microssocial para a cidade como um todo

Robert Park (Agier, 2011, p.66) apontava que há áreas de segregação natural no interior da cidade, não havendo uma política segregacionista voluntária. Estes enclaves são formados por laços étnicos ou como uma reação de uma comunidade frente ao preconceito. Progressivamente esses espaços se transformaram em regiões morais, estabelecendo uma distância social entre grupos moralmente diferentes do resto da cidade. A região permite visualizar as identidades externas que ocupam espaços específicos na cidade, partindo do pressuposto que tais identidades são primeiramente observadas por atores exteriores aos espaços considerados por meio de sua nomeação. Neste sentido, o Itatinga é uma região moral, criada por um projeto de segregação deliberada da prostituição que ao longo do tempo adquiriu uma identidade e conjunto de regramentos específico, tendo nome próprio e reconhecido nacionalmente como um espaço privilegiado do mercado do sexo. Portanto, esta ideia de região permite verificar como os atores classificam os espaços sociais independente das fronteiras e da escala na quais estas fazem parte, deste modo:

Corresponde a uma cartografia imaginária dos citadinos que vivem em 
certas partes da cidade continuando a ter sobre os outros espaços pelo menos algumas experiências ideias ou imagens. (Agier, 2011, p.67).

A situação, por sua vez, permite que o antropólogo acesse a cidade de forma mais abrangente ao não restringir sua análise etnográfica há um espaço social específico. Afinal, não são as fronteiras espaciais que definem a situação, mas os limites da interação (Agier, 2011, p.73). Para o citadino as interações podem variar de uma situação para outra em um mesmo dia, seja quando interage no trabalho, na família, no lazer etc. Podemos analisar as situações por intermédio de dois parâmetros: a situação na sua coerência interna e o setting, o quadro, a disposição dos constrangimentos (Agier, 2011, p.74). Neste sentido, há uma coerência interna nas situações que possuem um mínimo de sentido partilhado, uma percepção social dos atores das interações dadas. Finalmente, o quadro social é o contexto no qual ocorrem as interações, determinando em quais termos será possível realizá-las, existindo constrangimentos estruturais a ação dos atores envolvidos na situação, como por exemplo, a diversidade étnica e regional, as diferenças econômicas, o sistema político e administrativo e assim por diante.

Portanto, os atores em certa medida definem os termos da interação observando um sentido partilhado. Porém essa mesma situação possui constrangimentos estruturais que limitam a ação destes atores. A inventividade das situações dependerá do contexto na quais estas são construídas, ou seja, como este é mais ou menos estruturado e regulado (Agier, 2011, p.75). Assim sendo, como pode ser observado ao longo da descrição etnográfica desta dissertação, há nas diferentes interações descritas a presença de um script, de uma série de regulamentos que definem os modos de ação e diálogo dos personagens apresentados, seja pelo pertencimento ao bairro, o pensionato de travestis, ao quadro militante de movimentos sociais e assim por diante.

Por fim, com a finalidade de analisar a articulação das situações que ocorrem na vida dos citadinos é necessária certa noção de rede que permite conectar os atores inseridos nos vários contextos sociais da cidade, ligando o particular à totalidade. "A ancoragem é, ao mesmo tempo, individual (empiricamente) e estrutural (teoricamente)" quando se analisam os laços nas quais os indivíduos estabelecem entre si, construindo circuitos, identificáveis pela reconstituição das situações observadas que compõem a rede de relações na qual o ego, pensado como uma ponte de origem está inserida. A observação dos nós que 
compõem essa rede permite estudar os fenômenos de proximidade e distância social (Agier, 2011, p.79). O conjunto da cidade é compreensível para a antropologia como a rede das redes.

As redes se diferenciam entre si por meio das relações sociais de cooperação que as sustentam, aquelas que estão na sua base de sua existência, fornecendo para a rede uma função ou uso. Os laços de parentesco, a aproximação por sexo e classe de idade e a corresidência são mecanismos de cooperação que devem ser analisados em relação aos outros componentes da rede. Assim sendo, estes mecanismos de cooperação se correlacionam a outros componentes da rede produzindo efeitos sociais que as diferenciam, tais como as funções (seja econômicas ou políticas), o tipo de desenvolvimento formal, a inscrição no espaço e assim por diante. Portanto, a rede possui qualidades dadas pela relação do tipo de laço social que está em sua base com a função que possui, bem como o conteúdo moral mobilizado por ela (Agier, 2011, p.80).

No caso do Itatinga, a reunião em geral nas casas distintas de travestis e mulheres cria espaços de sociabilidade característica de um grupo especifico, por exemplo, em relação às trans que compartilham um estilo de vida e visões de mundo semelhantes. $\mathrm{O}$ Itatinga, por sua vez, é uma "região" direcionada ao comércio sexual, composta por um conjunto de casas, boates, motéis que se organizam diante da atividade da prostituição.

Porém, estar isolado em um bairro de periferia de Campinas, uma cidade no interior de São Paulo, não significa para as travestis estar fora de redes e trajetos, tanto da cena LGBT quanto da prostituição. Certa vez levei a pensão de Alice revistas e folders de boates e shows LGBT que havia trazido de São Paulo recolhidas da boate Queem, que fica próxima ao Largo do Arouche. Em uma mesa do corredor espalhei o material que começou a ser disputado como objetos valiosos por alunas e outras travestis que lá passavam, afinal cada uma conhecia alguém que figurava nas fotos ou boate que anunciava alguma festa. Jasmine, uma das alunas, contou-nos suas memórias ao ver nas imagens uma amiga drag que morava junto com ela nesta mesma região do Arouche há algum tempo. Ela também pontuou que o glamour de São Paulo a esgotava ao ser um trabalho noturno em que se gasta muito com roupas e baladas. Em sua avaliação, no Itatinga ela vive uma vida mais tranquila por trabalhar preferencialmente de dia, tendo a possibilidade de juntar dinheiro. Portanto, elas fazem parte de uma rede especifica, na qual reconhecem símbolos particulares, e o 
isolamento físico do bairro não as desconecta da circulação dos elementos presentes no estilo de vida que compartilham.

Desse modo, o Itatinga se conecta a circuitos outros, não necessariamente da prostituição, como por exemplo, o circuito do lazer LGBT, o circuito dos movimentos sociais, o circuito acadêmico, dado que desde sua criação é objeto de pesquisas científicas, e assim por diante. Muitas moradoras do bairro pertencem à militância de movimentos sociais, algumas inclusive possuem alguma notoriedade política na sua atuação política como Denise na história do Movimento LGBT campineiro e Bethânia no movimento feminista.

O circuito acadêmico, nesta lógica, foi fundamental para configuração da Associação Mulheres Guerreiras, que foi construída a partir do apoio da $\operatorname{ITCP}^{8}$ da Unicamp, "um programa de Extensão da Unicamp que tem como objetivo contribuir para o desenvolvimento da Economia Solidária a partir da formação de grupos auto gestionários e/ou cooperativas populares". Tendo contato com os universitários da Unicamp também ocorreu a parceria concomitante com o núcleo local da Marcha das Vadias. Por fim, vários estudantes oriundos destes espaços citados realizaram e realizam pesquisas acerca do bairro, incluindo Letizia Patriarca e Diana Helene. Esta última participou ativamente no documentário sobre a Associação Mulheres Guerreiras.

Assim, a organização de intervenções políticas e artísticas em parceria com movimentos sociais e de arte demonstra as ramificações das redes que se conectam ao Itatinga. Por exemplo, a intervenção artística do Coletivo PI, que conjuntamente com as mulheres e trans do bairro realizou um evento performático. Neste mesmo sentido, o "Puta Dei”, evento que acontece no dia 2 de Junho em várias capitais para lembrar a luta das prostitutas pela regulamentação da profissão, foi organizado pela Associação Mulheres Guerreiras nas ramificações dos diferentes circuitos na qual o bairro se conecta, seja o acadêmico, por meio das pesquisadoras que participaram ativamente do processo, da militância feminista e LGBT, da Defensoria Pública que estabeleceu alianças com as lideranças do Itatinga no momento de auxilio jurídico diante da ocupação policial de Outubro de 2013, e por fim, com a prefeitura por intermédio de funcionários ligados a defesa da diversidade sexual.

\footnotetext{
${ }^{8}$ Ver http://www.itcp.unicamp.br/drupal/.
} 


\section{As margens do corpo, da cidade e do Estado}

Em outras palavras: aquele que se exprime na faixa da marginalidade e da minoria coloca, sem dúvida, problemas que dizem respeito a esta faixa, mas que também dizem respeito ao conjunto da sociedade. (Guattari, 1996, p.123).

Como explicitamos na Introdução, este trabalho descreve o corpo e a sociabilidade trans inseridos no contexto do Jardim Itatinga, sendo que este bairro e os grupos sociais das quais fazem parte possui uma relação específica e múltipla com o Estado e seus vários segmentos. Assim, por ser uma localidade criada na periferia da cidade com a finalidade de segregar a prostituição a um espaço específico o bairro pode, em certos contextos, se deparar com uma faceta autoritária do Estado por intermédio da polícia. Por outro lado, através dos circuitos dos movimentos sociais dos qual o bairro participa, a dizer, os movimentos feminista e de prostitutas, bem como o LGBT, este se insere no Estado por meio da lógica da demanda por direitos, o que torna necessário mobilizar uma noção de Estado que reconheça a multiplicidade que este assume na prática política desta comunidade, especialmente das trans que é o foco central desta pesquisa.

A residência coletiva trans, por sua vez, é uma comunidade ocupada por indivíduos que não têm acesso apropriado a direitos tais como saúde, educação e segurança que levem em conta suas especificidades, em razão de sua orientação sexual, performance de gênero e atividade profissional que exercem. Porém, este campo de lutas pelo reconhecimento de direitos encontra-se em transformação dada a atuação dos movimentos sociais nas instâncias governamentais, fomentando políticas públicas que garantam o acesso à transformação corporal, o reconhecimento de um nome social pelos serviços públicos, bem como a retificação de registro, o atendimento adequado nas unidades escolares e pelos servidores públicos em geral como a polícia.

A pesquisa de Silvia Aguião (2014) analisa parte do processo de construção do segmento LGBT como sujeitos de direitos no Brasil contemporâneo, sendo a sigla uma coletividade imaginada produtora de um feixe de relações que perpassam movimentos sociais, a produção acadêmica e as políticas públicas. A análise da autora propõe fazer uma etnografia das instâncias de reivindicação do movimento coberto pelo início no ano de 
2008, a partir da convocação da I Conferência Nacional LGBT, e final em dezembro de 2011, data em que ocorreu a II Conferência Nacional LGBT.

Esta autora, com vistas a descrever a construção da identidade LGBT, bem como a incorporação desta pelo Estado, analisou documentos, observou eventos e a implementação das políticas publica específicas destinadas a esta população, dentre os quais o Programa Rio Sem Homofobia.

Aguião (2014) teve sua inserção em campo por intermédio de seu trabalho no Centro Latino Americano em Sexualidade e Direitos Humanos e por meio deste teve acesso as instâncias de debate e reivindicação do movimento LGBT. Portanto, ao longo de sua pesquisa foi necessário do ponto de vista metodológico dissociar a posição militante da de pesquisadora. Consequentemente, foi fundamental neste processo para a autora suspeitar de detalhes que pareciam óbvios e observar os significados presentes nas falas, discursos, gestos e ações dos sujeitos políticos observados (Aguião, 2014, p.5).

Esta posição de pesquisador e militante também enfrentei na elaboração desta pesquisa, e especialmente deste capítulo, pois dada minha aproximação com os movimentos sociais, seja o LGBT na figura de Denise Martins, ou ainda, da Associação Mulheres Guerreiras, reproduzi num primeiro momento o discurso militante da carência e das margens, o que não ocorre exatamente no campo, pois o Estado é acionado por estes grupos citados e suas demandas constroem a própria formatação do modo como se estabelece as políticas públicas direcionadas a estas populações em Campinas.

Denise, por exemplo, esteve presente na criação do Centro de Referência LGBT de Campinas, sendo uma figura reconhecida na militância local pela sua atuação. Assim, Régis, homem trans, funcionário do Centro de Referência da prefeitura, lembrou da atuação de Denise na criação das leis e entidades locais LGBT, que se tornaram referência nacional neste tipo de política pública, no evento que descreveremos adiante realizado pela defensoria pública no CEPROMM para esclarecimentos jurídicos sobre a mudança de nome no registro por pessoas trans.

O próprio evento do "Puta Dei", que também comentaremos adiante, encabeçado pela Associação Mulheres Guerreiras e pela Defensoria Pública, teve a participação crucial da prefeitura, na figura de Régis, oferecendo recursos materiais e espaços físicos para as mesas de debate. 
A presença de vereadores que se conectam aos movimentos em questão também é um fato, como exemplo, o vereador Carlão do PT. Este vereador, no episódio de violência policial que abateu o bairro, que será apresentado adiante neste texto, esteve presente na elaboração da denúncia para o Ministério Público sobre tal episódio.

Portanto, estas redes que incluem políticos profissionais, agentes do Estado, movimentos sociais, associações, pesquisadores, dentre outros, têm uma historicidade na construção do Movimento de Homossexuais, posteriormente denominado de LGBT, no Brasil.

Como observado por Facchini (2005), o movimento homossexual no Brasil pode ser dividido em três fases. A primeira onda do movimento inicia-se na década de 1970, com uma ênfase anti-autoritária e comunitária, sendo alternativo e libertário. A segunda onda, por sua vez, da segunda metade da década de 1980, foi marcada pela institucionalização do movimento e também pelo apoio de setores sociais como partidos, associações científicas e assim por diante, além da busca de uma imagem pública de legitimidade para a homossexualidade. A década de 1990 foi marcada pelas associações na construção de políticas de AIDS, ou seja, no financiamento público de iniciativas de enfrentamento da epidemia.

A resposta a epidemia fortaleceu os movimentos e incentivou a segmentação das identidades, pois as políticas públicas demandavam públicos alvos. Configurando um processo de aprendizado do fazer político administrativo, enfim, a trabalhar por projetos, ajustar os formatos das ONGs e assim por diante. Denise, neste contexto, estava auxiliando as amigas com AIDS e mobilizando uma rede de apoio que incluía a prefeitura e a igreja católica, tornando-se funcionária nesta época de projetos de combate à epidemia como exposto em seus depoimentos dados para o trabalho de Santos (2008).

Neste período também há um fortalecimento das relações entre o movimento social LGBT e os partidos com a atuação parlamentar em defesa dos direitos a diversidade sexual, como por exemplo, a proposição de projeto de lei sobre a união civil de homossexuais. Aguião (2014, p.12) demonstra que neste processo ocorreu um progressivo deslocamento da ênfase em questões relativas à saúde para reivindicação da garantia dos direitos humanos em sentido mais amplo como os direitos previdenciários, adoção, mudanças de registro civil, sendo que a incorporação destas demandas como direitos sexuais está relacionada à 
interpretação de que a discriminação priva estes grupos do acesso aos direitos.

Tendo isto em vista, Aguião (2014, p.14) propõe analisar o Estado encarnado nas práticas, afinal este se materializam em múltiplos lugares, objetos e pessoas, tendo como questão central compreender como certos direitos incorporam identidades e quais os formatos que administração governamental assume para incorporar esses sujeitos. Segundo Elias (2006, apud Aguião, 2014, p.13) há um caráter inacabado dos processos sociais, e, portanto na formação do Estado. Neste sentido, há uma aproximação dinâmica entre Estado/governo de seus processos de produção e funcionamento. Deste modo, a autora busca desvencilhar de proposições que reificam o Estado como entidade abstrata desvinculada às práticas:

Trabalho com uma abordagem que prevê o Estado não como uma dada unidade coesa, mas justamente busca investir na análise de processos de criação e recriação de morfologias do Estado governo (2014, Aguião, p.13)

Portanto, propõe compreender os processos de fazer-se no Estado, verificando os modos pelas quais o Estado produz os sujeitos que governa, mas também de como estes sujeitos fazem parte de um fluxo contínuo de produção do próprio Estado.

Assim, o Estado é construído pelos sujeitos políticos ao mesmo tempo em que este os constrói estimulando a estabilização de identidades. Neste sentido, Judith Butler (2008) aponta esta relação ao fazer uma leitura crítica da categoria política mulher, uma vez que as identidades são construídas dentro do contexto políticos das quais fazem parte.

Aguião (2014) ao observar as dinâmicas de construção dos sujeitos políticos do movimento LGBT coloca as seguintes questões: Quem são os sujeitos desses direitos congregados na siga LGBT? Como estas diferenças múltiplas se articulam em termos de reivindicação de direitos? Através de quais mecanismos determinadas marcas sociais são tidas como mais relevantes que outras na produção destas demandas? Como o entrecruzamento dos marcadores da diferença que caracteriza os sujeitos transforma-se em sistemas de classificação que se pretendem objetivos? Enfim, como são eleitas determinadas identidades estrategicamente em prol das reivindicações, ou ainda, como certas identidades se adequam a fim de obter legitimidade frente a certas demandas?

A autora conclui que manter-se no processo de reconhecimento pelo Estado requer 
do movimento a capacidade de equilibrar as tensões advindas deste relacionamento, ou seja, o que torna os "sujeitos LGBT" possíveis de serem administrados é o fato de conseguirem fazer sentido no interior das morfologias do Estado. Enfim, comportando-se enquanto "população 'imaginável', modelável, e adaptável dentro de certa gramática, cujas regras e limites são mais ou menos elásticos". (Aguião, 2014, p.239).

Esta compreensão do Estado proposta por Aguião (2014) se mostrou interessante a esta análise ao demonstrar que este não é uma instância abstrata, mas um processo de produção de sujeitos políticos ao mesmo tempo em que o Estado é produzido por estes. Deste modo, podemos compreender que as demandas LGBT no município de Campinas também formataram o modo como as políticas públicas em torno desta questão são produzidas na cidade, sendo este momento histórico da construção de Centro de Referência exemplar desta lógica.

No entanto, na observação semanal do pensionato presenciamos as dificuldades de efetivação de alguns direitos básicos, seja pelo acesso precário aos direitos sociais como educação, saúde, segurança e direitos trabalhistas, ou ainda, através de uma presença coercitiva do Estado em episódios de violação de direitos civis e humanos. Vejamos a seguir alguns destes aspectos relacionados as dificuldades enfrentadas no acesso ao direitos sociais e civis.

\section{As margens e a violência}

No caminho ao Itatinga ouvi pelo rádio que havia sido feita uma denúncia na corregedoria da polícia acerca dos casos de violência do último final de semana na região sudoeste de Campinas, e que esta se comprometera a investigar reconhecendo o inclusive o episódio de agressão arbitrária pela polícia motivada por racismo.

No dia 18 um policial foi assassinado nas imediações do bairro, sendo que sua motocicleta fora roubada. Diante disto policiais invadiram violentamente alguns bairros da região, incluindo o Itatinga. Várias pessoas foram agredidas e torturadas, tanto fisicamente quanto psicologicamente. Estes policiais estabeleceram um toque de recolher no Itatinga, que durou até terça-feira $(21 / 10)$ diante dos protestos de profissionais e comerciantes do bairro. Durante o período de três dias foi proibida a entrada e saída de pessoas do bairro, paralisando totalmente as atividades de prostituição. O caminhão de água mineral e o SAMU (Serviço de Atendimento Móvel de Urgência) foram impedidos de entrar 
no bairro. Os moradores não puderam circular entre as casas, inclusive travestis que moravam em uma casa e faziam refeições em outra não puderam circular. Quem tentou questionar o toque de recolher foi agredido. O pensionato de Juliana e Alice foi invadida, dentre outros imóveis.

O bairro hoje está triste, as mulheres não se exibem nas calçadas com as roupas sensuais habituais (...). Segundo Yara, a polícia havia jogado bombas e gás dentro da casa, e depois invadiu indo nos quartos, procurando uma menina que depois do ocorrido abandonou a residência. Esta menina, e outras que se abrigaram em um quarto foram salvas pela senhora manicure que se colocou a frente gritando que era apenas uma velha. No momento da confusão Yara ligou para vereadores e para alguns funcionários do CEPROMM, não sendo atendida. As meninas não puderam sair da casa por dois dias, inclusive as que moram na rua acima, mas vem fazer as refeições na casa. As que desobedeceram ao toque de recolher foram agredidas fisicamente. Alice não estava na casa, viajara naquele final de semana. (Caderno do campo, 31 de Outubro de 2013).

Nesta seção apresenta-se uma reflexão acerca das múltiplas expressões da violência no cotidiano do Itatinga, que dada a sua posição de liminaridade pode constituir-se em um lugar de exceção das leis, com a atuação de uma faceta autoritária do Estado, tanto para prostitutas ou clientes. Deste modo, descreveremos as percepções e vivências da violência no cotidiano das travestis e transexuais que residem no bairro, seja esta perpetrada pelos clientes, seja a engendrada pelos agentes estatais como explicitado no excerto acima.

Anthropology in the margins of the state é uma coletânea organizada por Veena Das e Deborah Poole, que reúne trabalhos antropológicos que buscam realizar uma "etnografia do Estado enquanto práticas, lugares e linguagens consideradas à margem do Estadonação.” (Das, Poole, 2008, p.19). A coletânea pretende desassociar as formas estatais analisadas como "forma de organização política administrativa racionalizada enfraquecida ou menos articulada" (idem). Poole e Veena Das sugerem que as margens do Estado são constituídas por lugares imaginados como selvagens e incontroláveis, porém são contextos nos quais o Estado é constantemente recriado, sendo as margens um efeito do próprio Estado, a "decorrência e implicação necessária do Estado, assim como a exceção é um componente necessário da regra". Na introdução, as autoras sugerem, a partir do postulado de Weber de que o Estado é o detentor do monopólio legítimo da força, que ele precisa a todo o momento se reafirmar por meio do discurso da desordem e ausência de leis, tanto do ponto de vista interno como externo (Das, Poole 2008, p.22).

As análises apresentadas no livro se concentram nas chamadas novas nações com 
Estados supostamente falidos na América Latina, no Sul da Ásia e na África. O foco central destas pesquisas é o exame de aparatos administrativos e hierárquicos que produzem uma ligação destas margens com o Estado, sugerindo que governos e burocracias se reafirmam nestes espaços através do fomento do uso da violência autorizada pelo Estado, bem como através de mecanismos de vigilância. Deste modo, o Estado mantém-se centralizado nestes locais onde supostamente é frágil, com um alto custo para a população.

Assim, dado o estigma da prostituição e a posição de liminar na qual se estrutura o bairro a violência pode ser uma das formas de relação com o Estado dado a fragilidade legal dos indivíduos que nele se inserem, seja prostitutas ou clientes. Partindo da percepção desta lógica, podemos descrever a posição do bairro como uma margem na qual a presença do Estado na sua dimensão policial pode se configurar como uma presença coercitiva e objeto de desconfiança, especialmente em relação à ação da polícia. Neste sentido, explicase o uso da violência policial desmedida e descarada no episódio recente de "vingança" em relação à morte de um agente. $\mathrm{O}$ bairro criado pela violência tem a potencialidade de sofrer rupturas críticas que reafirmam a fragilidade da vivência de um lugar como este dado sua existência marginal e excepcional como explicitado neste episódio de violência policial noticiado no jornal Correio Popular:

Moradores e comerciantes do Jardim Itatinga, em Campinas, reclamam da forma truculenta que a Polícia Militar (PM) tem agido no bairro após o assassinato do sargento Júnior Conejo do Prado, de 41 anos, baleado na noite de sexta-feira na região. Relatos dos moradores e dos comerciantes apontam violência, repressão e ameaças por parte dos policiais. A colombiana Rosário de Carmen, de 32 anos, que trabalha no bairro há cinco anos, acusa um policial de ter quebrado seus braços com um cassetete, além de lhe agredir, deixando vários hematomas pelo corpo. A agressão teria ocorrido na manhã de sábado, quando os policiais reviravam as casas em busca dos assassinos do sargento. (...)

Nos fins de semana o Itatinga, que costuma ser muito movimentado, ficou deserto. As casas, boates e bares estavam fechados. Moradores e os poucos clientes que chegavam eram abordados por PM's. A reportagem presenciou a ação de pelo menos cinco viaturas da PM e uma da Guarda Municipal. Um caminhão-guincho recolhia carros com irregularidades. Bares e boates permaneciam fechados.

"De domingo o movimento é grande. Há essas horas estaria tudo aberto e cheio de gente", conta uma garota de programa que se identificou apenas como Tatiane, de 42 anos. "Cliente que não sabe e vem até aqui tem o carro abordado. Nós não podemos sair que a PM manda entrar." O travesti A.S.M., de 36 anos, afirma que a situação é de cárcere privado. "Nós moramos aqui, mas não podemos sair para ir à padaria comprar 
pão que os policiais mandam voltar", disse. "Algumas meninas moram na rua de cima, mas comem aqui e ontem ficaram sem janta." Um comerciante que não quis se identificar disse que alguns já pensam em invadir a Rodovia Santos Dumont (SP-75) e fechar as pistas. "Até quando vamos ter que ficar fechados? Precisamos trabalhar", reclama. "Vamos queimar pneu, fazer alguma coisa", disse.

http://correio.rac.com.br/_conteudo/2013/10/capa/campinas_e_rmc/110

277-moradores-reclamam-de-truculencia-da-pm-no-itatinga-html

A carta abaixo foi escrita por Denise, presidente da Associação Mulheres Guerreiras, relatando um momento crítico de violência sofrido por toda a vizinhança desta região de Campinas. A carta, solicitada por telefone pelo psicólogo do bairro, foi lida em um congresso de psicanálise que acontecia na época:

Na noite de sexta-feira $(18 / 10)$ policiais militares abordaram de forma violenta e arbitrária as pessoas no Jardim Itatinga como retaliação a morte de um sargento da PM, vítima de latrocínio nas imediações do Bairro, no Jardim Telesp. Durante três dias o bairro permaneceu sitiado, onde a polícia atuou de forma machista, homofóbica e carregada de preconceito contra as profissionais do sexo que trabalham no bairro, os comerciantes e moradores locais. Durante o estado de sítio o abuso se perpetrou por meio de espancamentos, torturas, cárcere privado, omissão de socorro, agressões físicas e psicológicas. A omissão de socorro chegou a ponto de impedir e proibir o trabalho do SAMU que foi chamado para socorrer as vítimas. Os moradores dos bairros vizinhos, Jardim Campo Belo, DIC I e ocupação Joana D'Arc. Também foram abordados de forma violenta, com atos de agressão atemorizantes tais como no Itatinga, inclusive com posturas racistas por parte de policiais.

As profissionais do sexo, diante da violência, tentaram mobilizar outras entidades, mas sem sucesso. Não restando outra opção organizaram uma passeata, interrompendo o trânsito na Rodovia Santos Dumont, na segunda-feira (21/10), protestando contra a violação de seus direitos, somente desbloqueando a rodovia após os superiores da PM dialogarem com a Associação de profissionais do sexo, "Mulheres Guerreiras". Entendemos que atitudes como essa não contribui para reconstrução dos direitos humanos, viemos por meio deste espaço denunciar a atitude brutal da PM que opera e aciona discursos que engendram abissais desigualdades de raça, classe e gênero.

Reconhecemos a força e a luta dessas pessoas: Toda a força a Associação Mulheres Guerreiras!

Na semana destes eventos Yara, pedagoga, técnica especializada que trabalha em uma ONG que desenvolve ações de combate à homofobia e valorização da diversidade, viera passar uns dias na casa, pois a mãe morrera recentemente e ela procurou apoio em velhos amigos como Denise e Alice. Sentamos a mesa eu, Letizia, uma advogada, Denise 
e Yara, bem como outros visitantes amigos delas que lá estavam, e começamos a discutir os recentes fatos que haviam ocorrido. No dia dos eventos de violência Alice viajara, mas Yara estava hospedada na casa e nos relatou o momento de horror que viveu com a invasão da residência pela polícia, que inclusive jogara bombas de gás e perseguiu meninas que se esconderam nos quartos.

Neste dia ocorrera uma reunião na prefeitura, convocada pelo vereador Carlão do PT, para reunir informações e relatos das vítimas produzindo um documento de denúncia que foi encaminhado para o ministério público. Bethânia e Letizia haviam comparecido à reunião e ao retornar nos informou sobre as questões discutidas nesta. Bethânia, como apresentei anteriormente, é uma prostituta mulher, sendo atuante na Associação Mulheres Guerreiras e no movimento feminista, e nos dias dos fatos de violência acima narrados também estava no bairro.

Diante disto, coloquei a proposta que seria necessária alguma ação judicial por homofobia, já que se tratava de uma casa de travestis. Yara se irritou com a proposta, e disse que sendo travesti conhece esta face da polícia, pois já viu muitas amigas serem assassinadas e que apesar de não ter medo não havia como garantir a segurança das meninas da casa, e por fim, segundo ela esse "povo" que convocara a reunião dos direitos humanos na prefeitura queria apenas visibilidade política e que na hora que as coisas estavam realmente acontecendo apesar de suas insistentes ligações eles não apareceram. Denise também pontuou que não tinha medo, mas que temia pela integridade das meninas, mesmo que ela mesma já tenha enfrentado muitos policiais que insistem em tratá-las no momento de violência no masculino, e ao final nos revelou o desejo de oferecer um curso de direitos humanos para a polícia de modo que estes aprendessem a lidar com as travestis de modo apropriado.

Portanto, o Estado é percebido em certos momentos como lócus da obtenção de direitos, de serviços públicos, espaço privilegiado para o exercício da política e de reivindicações para setores militantes do bairro como Denise que pensa na possibilidade de reeducar pela cidadania os policias. Como já exposto no início deste capítulo, o Estado articula-se com a chamada sociedade civil, não sendo uma entidade abstrata que paira sobre sua clientela, pois é criado por esta ao mesmo tempo em que constitui estes sujeitos de direitos como observado por Aguião (2014). Nesta lógica, o Estado que Denise mobiliza 
em sua fala é distinto daquele que Yara denuncia como autoritário e perpetrador da violência. Deste modo, este trabalho de pesquisa teve que articular uma noção de Estado que descrevesse esta multiplicidade de atuações seja dos agentes públicos quanto das políticas construídas na demandas dos sujeitos que as reivindicam. Consequentemente, o Itatinga e os grupos sociais que nele se inserem têm múltiplas vivências do Estado, a dizer, aquele que atua com base no pressuposto da marginalidade desta população por intermédio da força, e aquele que inclui os movimentos sociais LGBT e de prostitutas como interlocutoras na construção de políticas e inclusive na fala otimista de Denise que se prontifica oferecer insumos para transformar o caráter autoritário deste outro segmento do Estado.

Para algumas travestis que perguntei sobre o fato depois do ocorrido obtive quase nada, estas não recusavam a falar sobre o assunto, mas o comentavam rapidamente, com respostas simples. Assim, no momento em que Denise e Yara estavam visivelmente preocupadas com os acontecimentos da semana anterior, expressando sua revolta, as travestis em geral, mesmo com certa apreensão ainda de ir à rua, não se envolviam com o assunto, demonstrando ou fazendo-se demonstrar certa ignorância aos fatos, apesar de muitas de suas colegas terem abandonado o pensionato pelo medo do que ocorrera.

Comentei com um colega, profissional de saúde do bairro, sobre este fato, levantando as hipóteses de que elas falavam pouco sobre o assunto por ser um episódio traumático, sendo uma forma de afastar a lembrança e lidar com o sofrimento. Ele, por outro lado, levantou a hipótese que talvez a falta de articulação da memória e da fala destas meninas sobre o evento que passara era um anestesiamento frente à violência cotidiana, afinal mesmo que no Itatinga a violência desta amplitude não seja habitual estas vieram de outras localidades e que já poderiam ter sofrido inúmeras vezes este tipo de abordagem.

Seguindo esta perspectiva de meu colega, interpelei várias meninas se já presenciaram no bairro episódios de violência praticada pelo Estado ou por clientes. Um grupo de travestis pontuou que existem pessoas de todos os tipos, seja policias ou clientes, e que estas na maioria das vezes são educadas e respeitosas ao procurar o serviço sexual, existindo também abordagens desrespeitosas e violentas, como por exemplo, a interpelação policial requisitando o nome masculino.

A violência por parte dos potenciais clientes, ou "passantes", é um fato do cotidiano, 
pois segundo o relato de algumas das meninas pessoas costumam atirar objetos nelas enquanto trabalham nas ruas. A frente do pensionato é um elemento de proteção coletiva, pois elas se juntam para reagir à agressão, por exemplo, recentemente quebraram o vidro do carro do agressor ao devolver a pedra que este havia arremessado. No entanto, a rua lateral à casa, que é utilizada também para a abordagem de clientes, é considerada perigosa, pois sempre há algum tipo de violência, especialmente o arremesso de objetos.

Ainda não há resultados quanto à investigação da morte do policial que desencadeou a invasão e ocupação deste bairro e de outras localidades ao redor. Possivelmente estas ações estariam apenas calcadas em rumores e hipóteses fundamentadas na ideia de que estas seriam localidades violentas, a margem da lei, passível de abrigar os criminosos que ordenaram a execução da vítima. Assim, podemos compreender em que bases se construiu por parte dos agentes policiais a intervenção violenta no bairro, não reconhecendo as liberdades individuais e os direitos humanos para estas populações localizadas na periferia, seja no DIC II, no acampamento Joana D’Arc ou no Itatinga.

O Estado aparece para esta população desde a criação do bairro, pela biopolítica e através do uso da força, ou seja, através das políticas públicas de saúde e por meio da presença policial. Porém, ao longo do tempo, a atuação política dos setores militantes do movimento LGBT e de prostitutas é produtora e produto de uma outra dimensão do Estado que pretende articulador de políticas públicas que efetivem direitos a estes grupos.

Em alguns relatos existe uma percepção do Estado como inerte, ineficaz na garantia de uma dada qualidade de vida, como me confessou uma prostituta da dificuldade de se registrar boletins de ocorrência de violência física e sexual contra profissionais do sexo, dado a insensibilidade das delegacias de polícia quanto a elas, constituindo momentos de ilegibilidade do Estado tanto pela vítima agredida, quanto pelos os agentes estatais que não as vêem como sujeitos de direitos. Uma das travestis da casa relatou que uma amiga que acompanhou à delegacia não conseguiu realizar boletim de ocorrência, sendo ignorada em relação à sua queixa na época claramente por ser uma travesti.

Porém, o bairro constitui uma localidade que apesar destas vivências de marginalização, ou justamente por esta, constrói intervenções políticas especificas a sua condição, seja através da militância da associação de prostitutas, seja de segmentos aliados 
dos movimentos feministas e do LGBT. Deste modo, é necessário refletir sobre como se faz política nas margens, ou seja, como esta população se constrói como ator político, pelo reconhecimento formal da profissão e das "casas de prostituição" ou pela dignidade cidadã frente à polícia.

A resposta da comunidade do Itatinga a ocupação e toque de recolher imposto pela polícia nos eventos de Outubro de 2013 possuem uma semelhança com a proposta política de Márcia Ochoa (2008) acerca das ações de empoderamento das "locas" na Venezuela. Esta autora questiona se há a possibilidade de construção de uma ação política "loca" para conquistar mais direitos para as "locas", e qual seriam os resultados de ações locais de proteção e empoderamento desses sujeitos marginalizados quando utilizados coletivamente, como por exemplo, o escândalo.

Mesmo que a prostituição não seja penalizada na Venezuela, em Caracas o código de ordenamento público estabelece sanções para os que sejam flagrados exercendo a prostituição. Diante disso, existe uma relação conflituosa entre a polícia e prostitutas, travestis e michês nesta localidade. Assim, realizando uma pesquisa quantitativa acerca da violência policial a autora verificou que $87 \%$ dos casos não são denunciados em razão do medo dos profissionais do sexo de serem alvos fáceis de novas investidas violentas. Uma travesti entrevistada a interpelou neste sentido: “¡¿Con La PM?! Ay no. Porque después cuando te vem en la calle, imagínate" (Ochoa, 2008, p.240). Deste modo, Ochoa visa compreender os processos de marginalização e como esta questão afeta a construção de projetos políticos, seja nosso imaginário acerca da cidadania ou da chamada sociedade civil, em especial a LGBT. A autora critica a institucionalização e profissionalização da sociedade civil representados pelas ONGs e ativistas LGBT e para prevenção e tratamento de DST/AIDS, bem como nos movimentos culturais de minorias étnicas nos EUA. Sendo que seu trabalho de pesquisa tem como foco as respostas corporais e imaginativas acerca dos processos de recepção da marginalização nos meios de comunicação e na intitulada "comunidade LGBT".

Na percepção da autora é necessário distinguir quem são os atores políticos e os que são excluídos desta esfera de atuação pública. Em seu trabalho de campo, na Avenida Libertador, Ochoa presenciou atos de violência perpetrados pela Guarda Nacional e PM's contra as travestis. Conforma a autora, estes índices de violência apresentados na Venezuela 
são o resultado da impunidade e perigo de se fazer uma queixa contra policiais neste contexto.

Com o termo "loca-lização" Ochoa descreve o entorno político das "locas", pois estas apesar de excluídas do imaginário político da sociedade civil organizada oferecem por meio de suas práticas de ação e resistência a possibilidade de se fazer uma política mais "loca" e mais políticas para as "locas". Estas estratégias de atuação das "fabulosas", “divas", "locas", "peluqueras" e "putas" tem a capacidade de transformar as concepções de poder, marginalidade e feminilidade, pois ao serem "atrevidas", em certos contextos, complicam a inclusão numa cidadania normativa ao não se conformarem com os modos esperados de comportamento para os bons cidadãos. Sobre os corpos destas "divas" a sociedade se impõe violentamente demarcando o território do gênero, e isto resulta numa exclusão social, econômica, jurídica e política. A ideia de cidadania, portanto, tem sido um mecanismo político para excluí-las. Nesta posição, como veremos, que se encontra o ponto de vista da Associação e da rede na qual esta se articulada no contexto do Itatinga.

Assim, Ochoa (2008, p.242), demonstra as diferentes modalidades de poder, suas suposições, subversões, inversões e perversões, e também como este se impõe na vida cotidiana das travestis, identificando que é necessário respeitar a criatividade e a força de vontade das pessoas marginalizadas. A autora questiona se é possível utilizar as micropolíticas do corpo e desejo da vida cotidiana marginalizada, como o escândalo, para produzir outras estratégias e concepções de cidadania.

A cidadania, conforme a autora, é a inclusão de uma pessoa na sociedade como sendo parte de um grupo reconhecido enquanto ator político, ou seja, na cidadania há um sentido de pertencimento (Ochoa, 2008, p.243). Assim sendo, ser um sujeito de direitos implica uma estética e comportamento esperado para um bom cidadão afim de que haja um reconhecimento social, fato este que complica a inclusão política das travestis que vivem do trabalho sexual e se utilizam do escândalo, por exemplo, como forma de ação e proteção frente aos problemas com clientes que se defrontam no cotidiano. $\mathrm{O}$ escândalo é uma forma de implicar o outro contaminando-o com a abjeção, tendo a finalidade de obter vantagens ou realizar vinganças, como por exemplo, expondo o cliente publicamente como homossexual enrustido (Kulick, 2008).

Dagnino (1998, apud Ochoa, 2008, p.246) identificou dois tipos de reivindicação 
de direitos, a dizer, o direito à igualdade $\mathrm{e} o$ direito à diferença. Assim, o direito à igualdade corresponde ao ideário liberal da cidadania. $\mathrm{O}$ direito à diferença, por sua vez, é recente, caracterizando-se como uma política cultural que implica redefinições da cidadania, incluindo-se nele, por exemplo, as pautas do movimento LGBT. Porém, segundo Ochoa (2008, p.246), há no interior destes próprios movimentos práticas de exclusão e limitação do imaginário político.

Existem também projetos de redistribuição afirmativa e projetos de redistribuição transformativa (Ochoa, 2008, p.247). Os primeiros buscam reparar padrões de distribuição sem questionar as bases que os produziram. Enquanto os projetos transformativos buscam alterar os padrões de injustiça, questionando e atacando suas bases. Deste modo, o escândalo se encaixaria na segunda forma, quando a travesti usa seu poder de contaminação advindo de sua condição abjeta para implicar o outro de modo que faça aquilo que ela deseja (Kulick, 2008). A autora propõe refletir que características que o escândalo adquiriria se fosse utilizado como estratégia coletiva. Como seria uma cidadania "transformista"?

Ochoa (2008) propõe que na construção de uma política anti-normativa é preciso levar em conta três aspectos: (a) a teoria queer, (b) usar estratégias locais e (c) articular uma política do desejo. A teoria queer nomeia-se por uma categoria êmica norte-americana, apropriada filosoficamente para questionar a matriz heterossexual e a cristalização política das identidades. Quando se projeta uma intervenção é necessário pensá-la localmente, ou seja, quais as respostas e soluções das pessoas afetadas? Articular uma política do desejo significa ter como ponto de partida o que os atores locais pensam (Ochoa, 2008, p.254-5).

Assim, ao perceber que a presença policial no Itatinga, no episódio de Outubro de 2013, se perpetuaria, os comerciantes, donas de casa e profissionais do sexo elaboraram uma estratégia de ação para chamar a atenção da sociedade para o problema que estavam vivendo e ao mesmo tempo afastar a polícia. Os clientes não podiam entrar no bairro, as travestis e mulheres não estavam autorizadas a circular dentro e fora do Itatinga. Segundo uma travesti, quem quisesse fazer programas em outro lugar teria que criar uma estratégia de "fuga", despistando a polícia até um ponto de ônibus. Os clientes que entravam despercebidos da situação em que o bairro se encontrava tinham seus carros revistados, e os que se encontravam em situação irregular eram guinchados, sendo que muitos 
automóveis foram apreendidos no período. Por fim, os comerciantes e "donas de casa", além da questão do constrangimento diante dos fatos narrados, enfrentavam uma crise econômica ao ficarem vários dias sem poder oferecer seus produtos e serviços. O que fazer, como reagir?

A estratégia coletiva adotada possui semelhanças como o escândalo, mas também com o formato tradicional das manifestações dos diferentes movimentos sociais: a passeata. As "putas", convocadas pela associação, pelos comerciantes e "donas de casa", partindo a ideia inicialmente de Juliana, paralisaram a Rodovia Santos Dumont com uma passeata na qual, vestidas apropriadamente para o trabalho sexual, com lingeries e roupas diminutas, seguravam cartazes contra a violência policial. Portanto, se nada acontecesse, ou seja, a polícia não desocupasse a região, o plano "B" seria desfilar peladas pela rodovia, conforme me explicou uma travesti que participara da movimentação. A estratégia de ação das prostitutas do Itatinga foi descrita pela seguinte reportagem do jornal Correio Popular:

Prostitutas e travestis pararam a Rodovia Santos Dumont (SP-075), no sentido Indaiatuba, na tarde desta segunda-feira (21), para protestar contra a ação da Polícia Militar (PM) no bairro Itatinga, em Campinas. Quem passava pela região, por volta das $12 \mathrm{~h}$, precisou esperar por quase uma hora, sob o sol, enquanto os manifestantes faziam uma barreira humana, na altura do $\mathrm{Km} 70$.

Cerca de 50 pessoas protestavam porque estariam sendo impedidas de trabalhar por policiais da Força Tática, desde a última sexta-feira (18), quando o sargento Júnior Conejo do Prado foi morto no bairro durante um assalto. O tráfego de veículos só foi liberado na via com a chegada da PM. (Correio Popular, 21/10; 2013). 


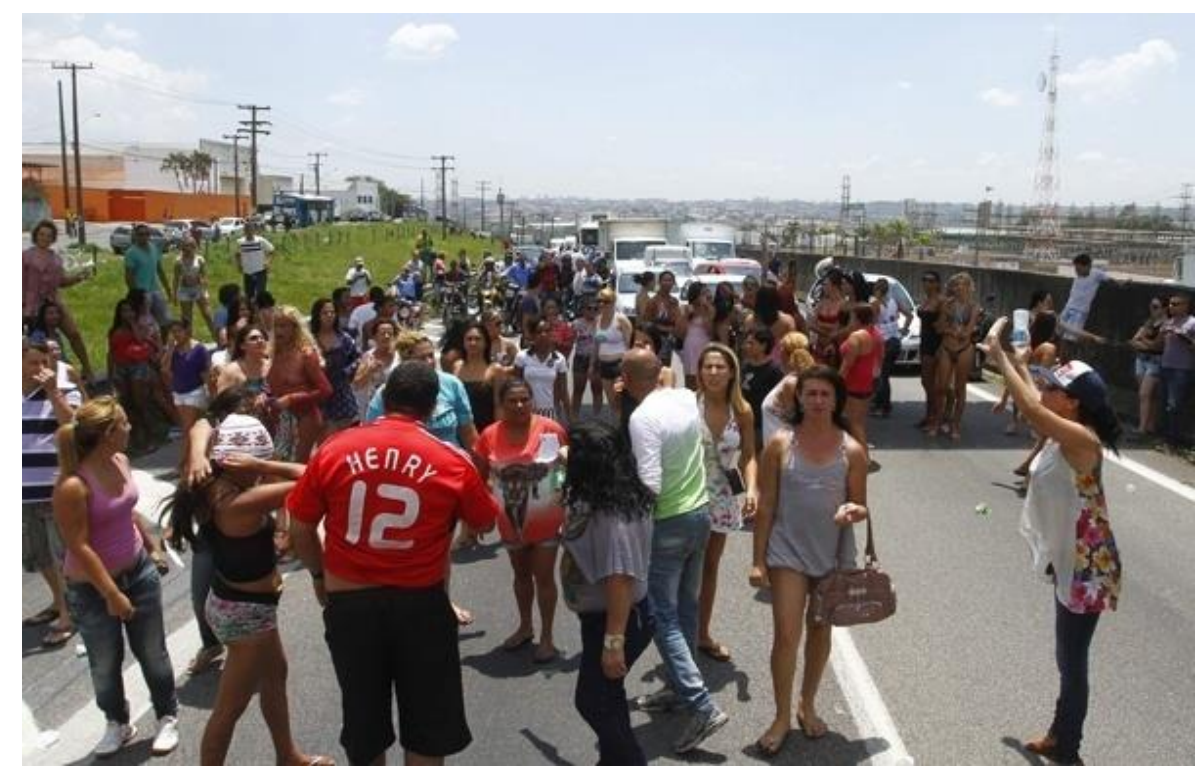

Há um conteúdo subversivo nas "putas” saírem dos limites da liminaridade e heterotopia do Itatinga em que estas foram confinadas historicamente. Adentrar os domínios da rodovia implica sair do cotidiano e "escandalizar" uma sociedade que lhes reconhece a existência, porém limitada a um espaço específico. Vejamos como esse ponto aparece na seguinte reportagem do jornal Correio Popular:

Espanto, estranheza, interesse, surpresa. A intervenção urbana Entre Saltos realizada na tarde desta sexta-feira (14) pelas ruas do Jardim Itatinga, em Campinas, alterou a rotina do bairro, considerado a maior zona urbana de meretrício da América Latina.

Trata-se de uma ação do Projeto Performance, realizado pelo SescCampinas, com execução do grupo paulistano Coletivo PI e colaboração da artista plástica mexicana Ana Teresa Fernandez.

A intervenção urbana teve participação de mulheres profissionais do sexo junto com outras pessoas que se interessaram pela oficina. O evento teve apoio da Pastoral da Mulher Marginalizada e Associação das Mulheres Guerreiras que, inclusive, cedeu o espaço para a realização das oficinas preparatórias no bairro. "A ideia é focar na metáfora do salto alto para discutir os vários papéis da mulher na sociedade".

A escolha do Jardim Itatinga foi a razão do bairro abrigar cerca de 2 mil mulheres. A proposta é analisar o equilíbrio e o desequilíbrio, o constante subir e descer do salto", explica a performer e diretora Priscilla Toscano, do

ColetivoPI.

A performance envolveu cerca de 40 mulheres, de diferentes profissões, caminhando juntas pelas ruas do bairro com um sapato de salto no pé e outro na mão, terminando na passarela de pedestres sobre a rodovia Santos Dumont, onde foi construído um monumento social a partir dos sapatos usados. (Correio Popular, 14/03/2014). 


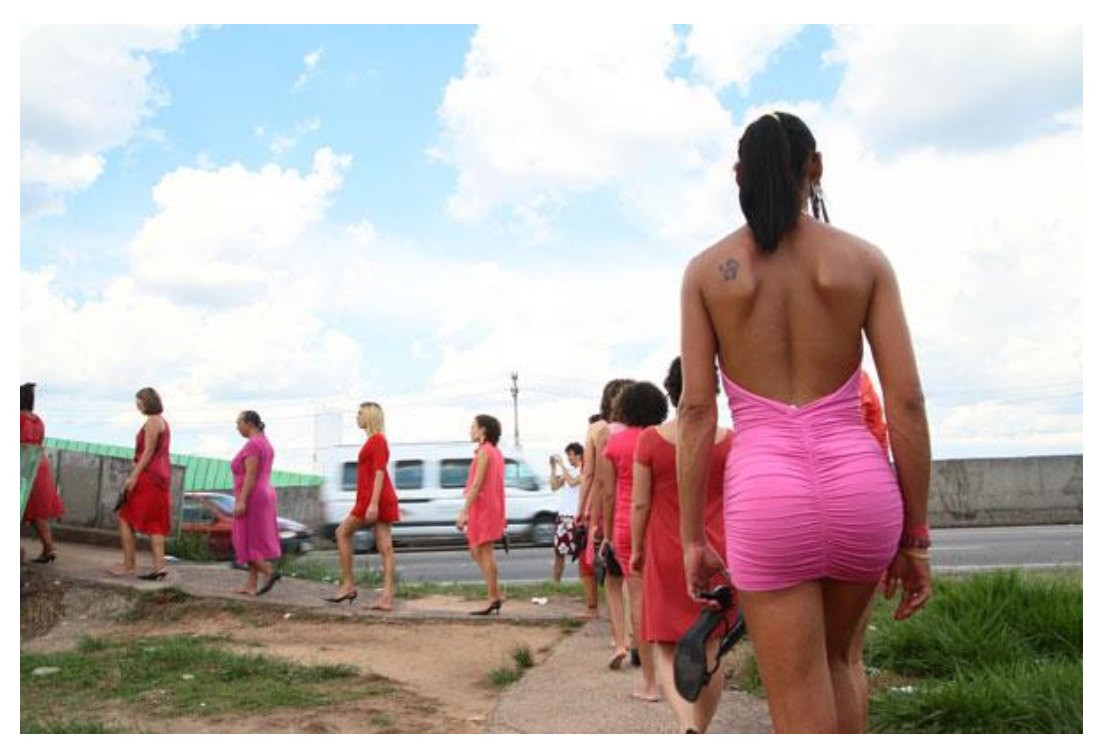

A intervenção artística citada faz parte de um projeto maior, realizado em vários espaços urbanos como uma diversidade de mulheres das várias profissões. Porém, no Itatinga esta intervenção artística, além dos seus objetivos originais, também adquiriu um sentido de performance "escandalosa", pois trouxe o conteúdo do bairro para fora de seus limites, assim, algumas das participantes relataram o desconforto diante do burburinho dos passantes da rodovia, mas que também estes estavam visivelmente incomodados com a presença massiva das mulheres do bairro fora de seus limites "naturais".

No dia 2 junho acontece o "Puta Dei”, evento que ocorre em vários lugares do país organizados pela Rede Nacional de Prostitutas e que tem como representante no Itatinga a Associação Mulheres Guerreiras lideradas por Denise, que é a presidente, e por Bethânia, vice-presidente da associação.

O Dia das Prostitutas é comemorado no dia 2 de junho como referência ao movimento francês ocorrido nesta data em 1975, quando 150 mulheres prostitutas ocuparam uma igreja em protesto contra a violência do Estado. O "Puta Dei" no Brasil, começou em Belém do Pará, em 2012, organizado pelo GEMPAC (Grupo de Mulheres Prostitutas do Estado do Pará). Na página do evento no Brasil podemos ler que:

As prostitutas queriam que a utilidade social de sua profissão, como verdadeiras educadoras sexuais, fosse reconhecida e conseguiram uma 
repercussão mundial, utilizando dos meios de comunicação e da conversa corpo a corpo - distribuindo impressos que diziam a gravidade da perseguição policial que sofriam. A partir de então, este dia é celebrado em várias partes do mundo como o Dia Internacional da Prostituta. (Disponível em: https://www.facebook.com/pages/PutaDei/486414241486425).

O evento em Campinas, no ano de 2014, foi realizado no salão nobre da prefeitura, no centro da cidade, sendo organizada uma mesa para discutir o Projeto de Lei Gabriele Leite. Também ocorreram nas ruas do centro atividades para visibilidade e reconhecimento das problemáticas das profissionais do sexo, contando com um desfile da Daspu, grife idealizada pela Rede Nacional Prostitutas, entidade que agrega associação de profissionais do sexo em todo o Brasil e luta pelo reconhecimento e contra o estigma da profissão.

Bethânia desfilou com a bandeira da CUT como uma provocação "escandalosa" ao posicionamento das mulheres da central sindical que pronunciaram publicamente que eram contrárias a aprovação do Projeto de Lei Gabriela Leite. As Mulheres da CUT (Central Única dos Trabalhadores) haviam se posicionado publicamente contra o Projeto de Lei Gabriela Leite de Jean Willys, que propõe a regularização das casas de prostituição, no dia 3 de dezembro de 2013, demonstrando a posição de um segmento do movimento feminista, e da própria CUT $^{9}$, que atribui à prostituição e à pornografia o papel de exploração da mulher numa sociedade patriarcal. $\mathrm{O}$ fato de Bethânia desfilar com a bandeira era uma provocação subversiva a estas posições, questionando a vertente do feminismo descrito acima ao demonstrar que as prostitutas são capazes de fala e ação por si próprias, e que no caso da Rede Nacional e da Associação estas defendiam a autonomia da profissional do sexo em fazer escolhas, sendo necessária a garantia de direitos a estas como profissionais. $\mathrm{O}$ argumento do movimento de prostitutas para a aprovação da proposta de lei de Jean Willys é que esta garantiria direitos trabalhistas e a fiscalização das casas para evitar a exploração do trabalho e a exploração sexual de menores.

Para finalizar este tópico é válido citar que em março de 2015 foi publicado no Diário Oficial da União uma resolução na qual o governo federal recomenda às polícias civis do Brasil que incluam nos boletins de ocorrência campos sobre orientação sexual, identidade de gênero e nome social dos atendidos em consonância com a reivindicação do

9 Ver http://www.cartacapital.com.br/sociedade/mulheres-da-cut-sao-contra-regulamentacao-daprostituicao-2612.html. 
Conselho Nacional de Combate à Discriminação e Promoção dos Direitos de Gays, Lésbicas, Bissexuais, Travestis e Transexuais da Secretaria de Direitos Humanos. Como observamos na fala de Denise e outras travestis, a abordagem policial violenta se inicia muita das vezes acionando o nome masculino como forma de coação e constrangimento transfóbico.

\section{Entre a Casa e o Estado: saúde, bem-estar e beleza}

A proposta de pesquisa inicial deste trabalho, como dito anteriormente, tinha como foco a questão da "saúde trans", observando o modo como as demandas destas eram atendidas no sistema de saúde. Porém, apesar deste grupo ter sido historicamente acolhido por meio de programas de DST/AIDS, ou através do enquadramento a tipologias médicas normatizadoras pré-estabelecidas, nos últimos anos verificou-se a preocupação com outras demandas como as de transformações corporais, por meio de iniciativas como, por exemplo, postos de saúdes especializados, além da preparação dos agentes de saúde para o atendimento adequado a estes indivíduos, com a utilização do nome social.

Segundo Michel Foucault (2002), a partir do século XIX normatizar as sexualidades se tornou um dos objetivos do Estado e da medicina. O autor aponta que entre os séculos XVII e XVIII apareceram técnicas de poder centralizadas no corpo individual. Mas também, atrelado à técnica disciplinar surge o biopoder destinado ao homem-espécie, sendo os alvos de controle da biopolítica os processos de natalidade, mortalidade e longevidade. O Estado realiza um biopoder, que tem como função regular a vida da população, na qual a regulação da sexualidade é central.

Aparece neste contexto do século XIX uma medicina preocupada com a higiene pública. E assim, se as tecnologias disciplinares do corpo visavam manejar o corpo individual, tornando-os úteis e dóceis, por outro lado, a tecnologia regulamentadora da vida, centrada na vida da população, buscava controlar os eventos produzidos por uma massa, calculando as probabilidades e efeitos dessas ocorrências. Deste modo, para a disciplinarização do corpo individual desenvolveram-se instituições como a escola, prisão, hospital ou quartel, e, para biopolítica da espécie, constituíram-se mecanismos 
regulamentadores da população por intermédio do Estado. Sendo assim, os mecanismos disciplinares e regulamentadores se inter-relacionaram historicamente, por exemplo, na configuração das cidades, seja pela disciplinarização dos corpos individuais por meio das instituições e saberes, ou ainda, em relação ao controle público da população na sexualidade, procriação, higiene da família, cuidado com as crianças, escolarização, etc.

Para Foucault, portanto, a sexualidade adquire importância, enquanto assunto público a partir do século XIX, através do controle disciplinar sobre os corpos por meio de uma vigilância permanente dos mesmos, mas também por meio da regulamentação biopolítica, afinal a sexualidade possuía os efeitos procriadores da reprodução da população. "A sexualidade está exatamente na encruzilhada do corpo e da população. Portanto, ela depende da disciplina, mas também da regulamentação”. (Foucault, 2002, p.300). Nesta mesma lógica, emerge a teoria da degenerescência, demarcando o tipo de sexualidade que era vista como perversa e indisciplinada, sendo significada como atrativo de uma série de doenças individuais, taxada como um risco a população. Como resultado disto, a medicina se torna um saber-poder direcionada ao corpo e a população.

A biopolítica e o biopoder também são definidores das margens do Estado ao ser o espaço entre corpos, leis e disciplina, pois o poder soberano do Estado não é exercido apenas nos territórios, mas também nos corpos (Das, Poole, 2008, p.25). Assim, o biopoder consiste nos meios em que o poder penetra nas ramificações da sociedade, tendo como foco fundamental a vida, sendo que as ciências biológicas e médicas adquirem centralidade ao ter o atributo de demarcar as fronteiras entre o normal e os "anormais". Conforme as autoras, as margens, nesta perspectiva do biopoder, são descritas como espaços de colonização da lei pelas disciplinas, que por sua vez produzem categorias patologizantes (Das, Poole, 2008, p.26).

Deste modo, as políticas de saúde são o reflexo dos valores relativos a norma heterossexual, se circunscrevendo especialmente na família nuclear, no sexo reprodutivo, na valorização da penetração pênis/vagina e outros modelos reguladores do dispositivo da sexualidade, excluindo as relações que escapam deste modelo. Os alvos preferenciais das políticas preventivas são os grupos desviantes, visando à regulação das práticas sexuais que escapam ao sexo monogâmico, procriativo e não pago. Por exemplo, Larissa Pelúcio (2007) observa que as políticas preventivas geralmente não são direcionadas aos clientes 
do sexo pago, mas às prostitutas e travestis.

No início da epidemia da AIDS se estabeleceu uma hierarquia de respeitabilidade sexual e moral, atribuindo uma posição de risco a sexualidade dos homossexuais, das "raças" negras e latinas, do gênero masculino, das prostitutas, etc. Ocorreu um esforço nos anos 1990 em desassociar AIDS e a ideia de grupos de risco, apontando a heterossexualização, a pauperização e a juvenilização da doença. No entanto, a associação entre AIDS e grupos desviantes continuou presente, configurando um processo de estigmatização. O grupo de risco, no senso comum, se traduziu como a necessidade de um cordão de isolamento moral (Pelúcio, 2007).

O projeto observado por Larissa Pelúcio (2007), em sua etnografia sobre os modelos preventivos de DST/AIDS, por sua vez, tinha como objetivo atrair as travestis para o posto de saúde, tendo como finalidade principal reduzir a incidência de AIDS entre os profissionais do sexo, resgatando o princípio da cidadania. O recurso metodológico utilizado era "educação entre pares", ou seja, o trabalho de base é feito por profissionais do sexo contratados para conscientizar nas ruas, se configurando como uma "prevenção dialogada".

A abordagem da prevenção dialogada é fruto das críticas aos outros modelos de ação em relação a AIDS, que não levavam em conta os contextos sociais específicos das diferentes populações alvo. Porém, a estratégia de politização adotada é sutilmente, conforme esta autora, uma forma de controle que busca responsabilizar os sujeitos pelas suas condições de saúde, ou seja, uma SIDAnização que conforma SUSjeitos que se autocontrolam, autovigiam e autogovernam. No entanto, muitos profissionais da saúde reconhecem a dificuldade deste tipo de proposta ao tomar consciência de que a AIDS é apenas um dos problemas que atingem os grupos sociais que dela sofrem, sendo inclusive secundária nas trajetórias de violência e exclusão dos pacientes (Pelúcio, 2007).

Havia também, na percepção da autora, uma incompatibilidade entre demandas e serviços ofertados. Assim sendo, os serviços de saúde que as travestis têm acesso são em geral destinados à prevenção e o tratamento de DST/AIDS, não havendo a disponibilidade de serviços que tratem de problemas de saúde presentes na realidade das travestis, por exemplo, com os problemas advindos da aplicação irregular de hormônios e do silicone industrial. 
Tendo isto em vista, como apresentei na Introdução desta dissertação, meu projeto de pesquisa inicialmente tinha como finalidade analisar as relações entre transgêneros e o sistema de saúde. Deste modo, visava identificar os diferentes sistemas simbólicos dos agentes sociais envolvidos nesta relação, tais como os diferentes significados de beleza, saúde, e drogas, nos discursos e práticas de profissionais de saúde e travestis.

Porém, para a pesquisa de campo foi necessário escolher um lugar privilegiado de observação e que este fosse original levantando novas questões relevantes a esta área de estudos. Assim, as capitais já possuíam pesquisas sobre a temática, algumas inclusive circunscritas ao âmbito da saúde, e que o interior de São Paulo apontava como um lugar produtivo para o levantamento de novas questões acerca do tema. A partir disto, iniciei as incursões a campo no Itatinga, especialmente no pensionato de Alice e Juliana.

Dentre as questões iniciais suscitadas estavam a especificidade de atuação do posto de saúde local, pois este se inseria numa localidade que tem como principal atividade econômica a prostituição. Um outro ponto que me interessou neste contexto foi observar as estratégias de construção corporal utilizadas pelas trans do bairro, e de qual era o papel do pensionato neste processo. Por último, mostrava-se necessário investigar o papel do sistema de saúde na produção deste corpo, inclusive por meio da atuação do posto de saúde.

O posto oferece serviços de prevenção e tratamento de DST/AIDS, com o cadastramento e distribuição de preservativos e medicamentos, havendo inclusive visitas dos profissionais de saúde aos diferentes pacientes, como é a prática das UBS em outros bairros. Também ocorrem campanhas de conscientização em torno das doenças sexualmente transmissíveis, mas também em relação à aplicação do silicone industrial, sendo que tais estratégias de atuação local são mediadas através de reuniões com a comunidade, lideradas pela Associação Mulheres Guerreiras, na qual se mantêm "conversas" constantes com Denise e Bethânia, dentre outras militantes. Uma destas reuniões, por exemplo, tratou da disponibilização de gel, pois Bethânia, percebendo que em outros lugares do país havia a distribuição deste material, resolveu colocar esta demanda.

Assim, a atuação da unidade de saúde é local, com recursos e limitações específicas. Dentre os recursos que possuem é esta capacidade de mediar suas ações com a comunidade, tendo eficiência, por exemplo, na conscientização em relação ao silicone industrial. Isto 
demonstra uma perspectiva diferente da unidade justamente por sua condição de localização que acaba por reconhecer demandas de saúde outras, tais como a questão das transformações do corpo, deste modo, a ginecologista local faz o acompanhamento do processo de hormonização das meninas.

Nestas primeiras incursões a campo pude verificar que o uso de silicone industrial se torna cada vez mais tabu entre as travestis, em função das campanhas de conscientização. Quando questionei sobre o uso deste material Alice me repreendeu, pois segundo ela esta seria uma prática ilegal e perigosa. Alice e Juliana proíbem as meninas da casa de se bombar (colocar silicone industrial) no bairro, e quem quiser realizar este procedimento deve procurar "bombadeiras" no centro de Campinas.

A residência coletiva, por sua vez, é o elemento central na construção de um corpo transformado, pois no interior desta é que se trocam informações para feminilizar-se, incluindo o conhecimento de hormônios e de tratamentos estéticos. Mas, também é através da casa que estas têm o acesso à colocação de silicone dos seios, pois Alice e Juliana organizam "caixas" individuais, com o dinheiro recolhido pelo trabalho ao longo do tempo, ou emprestam dinheiro para que as meninas realizem tal cirurgia. A "colocação de silicone" para algumas é a razão mesma do trabalho, assim, certa vez uma travesti me confessou ter preguiça de ir para "rua" afinal já atingira seu objetivo de colocar peitos.

Deste modo, a vivência na casa e bairro está intimamente ligada à questão da cirurgia de implante das próteses. Em pouco tempo de trabalho, de 4 a 6 meses, o dinheiro para os seios já é arrecadado, dependendo da capacidade e disposição da travesti para tanto. "Guardar o dinheiro" com Alice, contudo, não é algo apenas destinado ao silicone, mas também a outros projetos de vida, por exemplo, obter uma carteira de motorista ou um carro, como é exemplificado pelo projeto atual de Natalie. Por outro lado, a "Mãezinha" também pode emprestar dinheiro para alguns projetos menores, como a compra de óculos, a colocação de Meiga Hair, ou ainda, a retirada dos pelos corporais com laser.

No entanto, o acesso aos serviços de saúde está ainda muito restrito a uma abordagem normativa, dada as dificuldades daquelas que procuram o sistema público para transformar o corpo, seja para hormonoterapia, cirurgia de mudança de sexo ou colocação de próteses. Isto se deve a um entendimento dos profissionais de saúde envolvidos no processo de acesso a estes serviços, pois estes estabelecem o parâmetro de coerência destes 
corpos a partir da diferenciação entre transexuais e travestis. Essas dificuldades foram expostas pelas participantes do evento que a Defensoria Pública organizou no CEPROMM em Junho de 2014, com a psicóloga Karina e a assistente social Andressa, ambas do Centro de Referência LGBT, e a defensora pública Vanessa do Núcleo Especializado de Direitos Humanos da Defensoria.

O Conselho Federal de Medicina estabelece que é necessário um acompanhamento por equipe multidisciplinar por dois anos para que o paciente possa realizar a cirurgia de transgenitalização pelo SUS (RESOLUÇÃO CFM no 1.955/2010). A Portaria $\mathrm{N}^{\circ} 2.803$, de 19 de Novembro de 2013 atualmente regula os parâmetros do processo transexualizador no Sistema Único de Saúde.

No evento realizado no CEPROMM, no dia 26 de junho de 2014, sobre as "identidades trans e o papel da defensoria", Vanessa Alves Vieira, defensora especializada em ações judiciais dentro desta temática, elenca que as maiores problemáticas enfrentadas hoje em dia quanto à saúde estão na limitação de 21 anos de idade para o acesso aos procedimentos transexualizadores pela portaria do Ministério da Saúde contrariando a resolução do CFM, o entendimento de que o acompanhamento por equipe multidisciplinar consiste apenas em tratamento psicológico, e por fim, a necessidade de um laudo psiquiátrico com o diagnóstico de transexualismo, excluindo as que se identificam como travestis do acesso a cirurgias de mudanças corporais no SUS. No sistema jurídico, por sua vez, Vanessa A. Vieira constatou que os juízes compreendem em sua maioria a necessidade de cirurgia de transgenitalização ou laudo psicológico que ateste a transexualidade para a mudança de nome, apesar de não haver nenhum marco legal que regule neste sentido a retificação de registro.

Segundo ela, as categorias têm sido úteis apenas para negar direitos ao invés de oferecê-los, afinal a classificação adotada muita das vezes distingue travestis como aquelas que se sentem à vontade como seu órgão sexual e transexuais como aquele grupo que sente desconforto com o pênis desejando a cirurgia de transgenitalização. Porém, além da exclusão, portanto, do acesso a serviços de transformação corporal no serviço público para as que se autoidentificam como travestis, estas distinções não levam em conta a diversidade que as classificações assumem no cotidiano das pessoas, afinal, como exemplificado pela fala de Luana Kelly no evento, uma das meninas do pensionato, "tenho 10 anos de travesti, 
será que fica mais fácil com isso conseguir mudar de sexo?”. Em Campinas não há a possibilidade de realizar este tipo de cirurgia e atendimento, apenas a hormonoterapia acontece por meio do aconselhamento dos médicos nas unidades de saúde. "Mudar de sexo" no sistema privado, por sua vez, ainda é muito caro, existindo poucos profissionais que realizam esta técnica.

A percepção das usuárias quanto ao Estado também se faz relevante neste tópico da saúde, pois minhas interlocutoras afirmaram ter havido épocas de melhor eficiência das políticas de saúde no bairro dado a maior posse de recursos e a disposição de agentes estatais ligados à comunidade do Itatinga e LGBT. Neste trecho do diário de campo que se segue podemos observar esta percepção:

Perguntei sobre o assunto da mudança sentida no programa de DST/AIDS de Campinas que Bethânia e Denise haviam me falado há um tempo. Segundo elas havia nesta época citada uma maior disponibilidade de verbas e flexibilidade na implementação de projetos, o que tornava a relação com programa municipal de AIDS mais produtivo e agradável. Por exemplo, nesta época, oferecia-se lanches para as profissionais no momento de coleta de exames e oficinas, bem como havia espaço para desenvolver projetos que não eram diretamente envolvidos na prevenção de DST/AIDS, mas que tinha como foco a educação e autoestima. Segundo Denise, as meninas nesta época inclusive puderam realizar excursões com o pessoal da prefeitura, indo por exemplo, numa visita ao museu do Ipiranga. De acordo com Bethânia, o PMA possuía uma equipe diversificada e atuante, e a ligação que estabelecia com o bairro para implantação de projetos era intermediada por uma funcionária travesti contratada por cargo em comissão. Isto permitia o reconhecimento de demandas de saúde específicas a elas, como a questão do bem-estar psicológico.

Bethânia me contou que ocorrera desde 2010 uma interrupção neste bom relacionamento, em razão do afastamento da coordenadora do PMA provocado por uma confusão criada pelo vereador Peterson Prado, que tinha interesses pessoais ao motivar tal evento. Desde então, não existe mais projetos alternativos no PMA direcionados a elas, bem com o atendimento personalizado de outrora.

Peterson Prado voltou-se contra a coordenadora, afirmando em CPI (Comissão Parlamentar de Inquérito) de que havia irregularidades no programa, com inclusive desvio e mal uso de dinheiro público. Desde então, o PMA não é o mesmo como afastamento dela e de sua equipe, inclusive a travesti ligada aos projetos do Itatinga. (Diário de Campo, 28/11/2013).

Há poucas referências documentais sobre o ocorrido, a não ser o vídeo da CPI na 
câmera de vereadores ${ }^{10}$. O fato é localmente produziu-se uma visão específica dos fatos, verificando-se para estas uma relação mais interessante com a Secretária de Saúde antes do ocorrido.

O Estado, independente dos fatos que realmente ocorreram nas mudanças em torno das políticas públicas de saúde em Campinas, aparece para as usuárias alvo destes projetos em termos da inegilibilidade em torno de suas práticas ao ser vivenciado no cotidiano das pessoas. Segundo Das e Poole (2008, p.25) há em certos contextos, uma compreensão nebulosa nas margens acerca das intencionalidades das políticas públicas. Portanto, ouvir a percepção das usuárias acerca das mudanças no Programa Municipal de AIDS é produtivo ao verificar através de suas falas expectativas de como este deve se concretizar no cotidiano das pessoas. Ou seja, para elas neste caso o Estado deve adquirir uma faceta humanizada que leve em conta todos os aspectos da vida das residentes do Itatinga, inclusive as da autoestima e bem-estar psicológico, oferecendo um serviço público que não as trate como uma simples senha que realizará um exame. Portanto, elas expressam através dessas falas um desapontamento frente à atual conjuntura, pois desejam um Estado que seja próximo de suas usuárias e não uma instância impessoal e deslocada do cotidiano das pessoas.

\footnotetext{
${ }^{10}$ Ver http://www.youtube.com/watch?v=9ewIBQbdN0I Vereador Peterson Prado denuncia a máfia do esquema de corrupção do programa municipal de AIDS em Campinas e http://www.youtube.com/watch?v=w8-ylgj2HJM Vereador Peterson Prado fala sobre os prejuízos dos medicamentos pra AIDS usados pelos portadores do HIV, que em muitos casos dão mais efeitos colaterais do que benefícios.
} 


\section{CAPÍTULO 3. A educação para uma transcidadania}

O objetivo deste capítulo é refletir sobre a especificidade da sociabilidade escolar de pessoas que realizam o trânsito entre as performances de gênero masculinas e femininas, seja em termos de práticas ou identidades. Nas próximas páginas, apresento reflexões acerca do que foi experienciado no trabalho de campo sobre a relação das pessoas trans com a Escola, mas irei igualmente mobilizar algumas das situações e inquietações que vivi como professora do Ensino Médio.

As inquietações que registro e analiso aqui resultam daquilo que experimentei em campo, mesmo quando fazem referência a espaços e contextos fora do Itatinga. De fato, a apuração do olhar etnográfico para o problema da educação fez parte da dádiva que recebi durante a época do ensino do inglês para as travestis do pensionato de Alice e Juliana, que transformou minhas percepções como educadora em relação ao papel do gênero na Escola.

Iniciarei desenhando um quadro descritivo e analítico do território que tanto Jaqueline quanto July lutam cotidianamente para estar, dado o reconhecimento da existência de certo capital conferido a quem minimamente teve acesso à escolarização. Jaqueline é uma transexual adolescente que se matriculou na escola em que trabalho, sendo que, mesmo após ter passado por experiências traumáticas em outras instituições de ensino resolveu retomar os estudos. Como veremos adiante, no entanto, ela não conseguiu resistir à pressão de uma ambiência marcada pela incompreensão e transfobia abandonando os estudos novamente. July, por sua vez, é uma moradora do Pensionato de Juliana que, motivada por Alice, também retornou à escola no EJA (Educação de Jovens e Adultos) e conseguiu se alfabetizar a despeito das dificuldades que encontrou no caminho para Escola em razão das abordagens transfóbicas que sofria neste percurso.

Assim sendo, este mapa da escola e das trans-formações de gênero será desenhado por intermédio de algumas experiências etnográficas que permitem uma reflexão acerca de como a escola se pensa e é pensada em relação a gênero.

\section{A Mãezinha como educadora}


Como veremos adiante, a questão do acesso à educação ainda é precária para as pessoas trans, sendo a escolarização uma condição fundamental para a cidadania. A escola, nesta lógica, continua a ser um espaço atravessado pela violência homofóbica e de gênero, seja do ponto de vista físico, seja simbólico. No entanto, existe um debate na esfera pública em torno da transformação política deste espaço de modo que seja inclusivo e garanta o acesso de travestis e transexuais à escola, fomentando propostas e a implementação de políticas públicas, bem como uma nova perspectiva pedagógica para esta instituição. Porém, a educação não é necessariamente um conjunto de conhecimentos consolidados na ambiência escolar e podemos dizer que há uma dimensão educativa na atividade de aprendizado de ser uma travesti que a residência coletiva oferece, por meio de suas "mães", bem como o de ser uma travesti militante, através de uma militância que busca a conscientização política de seus pares.

Como já sinalizei neste texto, a residência coletiva no Jardim Itatinga possui regras rígidas de trabalho e convivência. Assim, no Pensionato de Alice e Juliana, por exemplo, é proibido o uso de certas drogas e o consumo excessivo de álcool. Certa vez quando comentei sobre o cuidado que as meninas tinham com o cabelo, Alice observou que é apenas autorizado se arrumar e alisar os cabelos com "chapinha" pela manhã, no horário de menor movimento, caso contrário, segundo ela, as meninas se penteariam o dia todo, se esquecendo de outras atividades. Como observado anteriormente, existem geralmente multas pelo não cumprimento das regras e compromissos acordados.

Ao observar a rotatividade de pessoas na residência, Natalie, uma das travestis aluna do curso de inglês, pontuou que há muitas pessoas que não conseguem seguir corretamente as regras do pensionato, e que por isso acabam abandonando o local para ter liberdade para o uso de drogas, não ter compromissos com horários, como acordar cedo ou alimentar-se no horário correto. Segundo Natalie, o pensionato de Alice e Juliana é diferente de outros lugares pelos quais passou justamente por oferecer esta disciplina, que para ela é um elemento muito positivo, pois favorece o desenvolvimento pessoal. Dentre outras especificidades citadas por ela como elementos positivos desta residência coletiva está o incentivo a trabalhar durante o dia em que há mais segurança, bem como o apoio para quem quer estudar. Por exemplo, ela recentemente conseguira sua carteira de motorista justamente pelos conselhos de "Mãezinha" Alice. Outro elemento positivo do pensionato, 
segundo ela, é o não pagamento da diária por travestis que possuem algum tipo de problema, como uma deficiência intelectual ou problema psicológico mais grave, por exemplo.

Muitos autores e autoras vêm discutindo os novos sentidos que relações entre pessoas não heterossexuais ou não cisgênero podem trazer para a teoria social, especialmente no que diz respeito à dimensão do parentesco. Nesse sentido, em $O$ grito de Antígona, Judith Butler (2001) sugere que o parentesco, no nosso caso especificamente ser mãe, implica em posições sociais nas quais há múltiplas possibilidades de exercício de ocupação das categorias. Kath Weston (1997) descreve a configuração do "parentesco gay" historicamente articulado em uma rede de apoio mútuo diante do afastamento da família biológica. No Itatinga, a residência coletiva parece em muitos sentidos ocupar esse lugar de apoio mútuo, sendo as relações ali inclusive descritas em termos familiares. Assim sendo, Alice, a "Mãezinha", é uma matriarca que agrega as travestis da região e é o símbolo de afeto e cuidado.

Sendo uma das administradoras do pensionato de travestis, Alice é chamada carinhosamente de "Mãezinha", uma variação em termos de classificação da "mãe", já descrita nas etnografias de Larissa Pelúcio (2007) sobre a prostituição trans. As mães seriam aquelas travestis responsáveis por socializar a novata nas regras e códigos de ser travesti e também de estar na rua. Algumas mães administram casas que abrigam as travestis. Estas casas são refúgios, espaços habitáveis, que também se estendem à vizinhança durante o dia, dado que a rua em outros locais em geral é o lócus do preconceito. A noção de mãe traz, além da noção de cuidadora, a de participante ativa e professora na construção do corpo travesti. Neste sentido, Pelúcio nota que muitas bombadeiras (travestis que realizam a aplicação de silicone industrial em outras travestis) são tidas como mães, pois auxiliam no processo de construção da feminilidade $(2007$, p.244) - na residência de Alice e Juliana é proibida a aplicação de silicone industrial, realizado, no caso de Campinas, apenas no centro. Como vemos neste trecho do caderno de campo, Alice tem esta função de acolher as novatas e as inserirem nas dinâmicas da casa, ou ainda, orientálas no processo de construção do corpo feminino:

Uma jovem travesti, ainda um "gayzinho", chegou recentemente a casa e pediu conselhos para Alice de como se tornar travesti, ela é irmã de uma 
moça que já reside no pensionato há um tempo. Enquanto eu, Letizia, Natalie, Jasmine e Tatiane ensaiavam a música do Bruno Mars, para uma futura apresentação as colegas, numa mesa na varanda, a nova travesti ainda sem seios e muito magra passava várias vezes por nós, vestindo a cada hora roupas e sapatos diferentes. Ela transparecia felicidade ao poder exibir-se deslumbrante no portão. Alice ao ver a cena riu, nos falou que ela chegou há pouco tempo pedindo auxilio para se tornar travesti, perguntei se já tomava hormônios, "Mãezinha" respondeu que ainda não, pois era jovem e estava iniciando-se neste processo. (Caderno de campo, 10/12/2013).

A "mãe" tem a função de colocar a travesti na linha, repreendendo aquelas, por exemplo, que usam drogas ou não cumprem com os compromissos da casa. "Só se a fillha não ficar devendo. Aí querida, a mãe vira madrasta rapidinho. É babado”, afirmou uma travesti para Larissa Pelúcio (2007, p.248) sobre esta relação de afetividade. Dona Alice, por exemplo, disse não ter ido a uma parada gay no centro de Campinas para evitar se estressar, pois fica muito nervosa com as meninas, tendo que as repreender e resolver eventuais problemas neste tipo de evento. Em outra ocasião, Katy arranjou uma briga em um baile funk e "Mãezinha" confessou que se fosse necessário "puxar um pau" para corrigir este tipo de atitude ela faria. Neste outro trecho podemos observar esta relação especial com "Mãezinha":

Enquanto estávamos conversando várias meninas abordaram "Mãezinha" para emprestar dinheiro que hora era dado ou não. Alice nos confessou que havia se tornado quase que uma mania, pois elas até que eram boas pagadoras, mas não há como fornecer dinheiro a todo o momento. Joyce, uma travesti de cabelos vermelhos, também nos interrompeu, reclamando das intrigas de uma colega que implicara com ela sobre a demora no pagamento do cabelo, pontuando que esta também deveu por muito tempo os óculos que Alice comprara em seu cartão. Quando o desafeto de Joyce passou por nós "Mãezinha" falou a ela que o "caso" dela estava brava. Esta travesti deu risada, e falou que esta colega já havia levado uma bronca de Juliana por falar sobre o óculos e que não era mulher de levar "coça". Alice nos explicou a história. A de cabelo vermelho colocara mega-hair com dinheiro emprestado dela, porém demorara a pagar mesmo diante das várias vezes que chamou a atenção para o fato, e que mesmo assim ela insistira a ficar na cama sem fazer nada ao invés de trabalhar para conseguir o dinheiro. A moça dos óculos o comprara no cartão de Alice e não fazia questão de pagar e trabalhar, assim ela se viu obrigada a descontar o dinheiro do caixa acumulado por esta travesti para colocar silicone. Alice nos confessou que elas não se agridem fisicamente por terem medo de pagar multa, que neste caso é financeira. (Diário de campo, 06/02/2014). 
Assim, observamos que cotidianamente as travestis abordam Alice com beijos e abraços, ela inclusive ganha quase sempre pequenos presentes, como refrigerantes, bolos, chocolate, celulares, enfeites de decoração, utensílios de cozinhas etc. Deste modo, a relação da "Mãezinha" com as meninas não se restringe a um relacionamento profissional, mas também envolve questões de afeto, respeito, educação e de autoridade. Segundo Alice, ela é a "Mãezinha", pois sendo Juliana oficialmente a "mãe" as meninas escolheram chamá-la assim. Porém não se observa a mesma relação de proximidade e afeto com a Juliana dado seu papel de regular com mais rigidez a disciplina do pensionato. Vejamos outro trecho do diário de campo:

As colegas começaram a brincar com uma travesti que se aproximava, de que ela era amiga e cliente contumaz da cigana. Perguntei a elas o motivo da gozação, estas explicaram que esta travesti havia gasto mais de R\$2000 reais em "trabalhos", e que por isso levou uma bronca de Juliana, pois não se esforçou para pagar esta dívida. Segundo Drica havia um "terreiro" na rua de cima, mas agora já não existe mais, porém a "mãe de santo" que fez esta cobrança da travesti em questão ainda reside no bairro. (Diário de campo, 18/02/2014).

Como um profissional da saúde que trabalha nesta região me informou, existe tanto em residências coletivas de travestis quanto de mulheres do bairro esta linguagem do parentesco e é necessário investigar como se processa esta relação em casas habitadas apenas por mulheres.

Weston (1997) fez uma etnografia entre as redes de sociabilidade na comunidade homossexual americana que se apropriava da linguagem do parentesco, estabelecendo um conjunto de obrigações de apoio mútuo e afetos pautado pelo vocabulário da família. A autora lança mão da noção de parentesco escolhido, chosen familiy, como uma rede de laços simbólicos pautados na oposição entre biológico e construído (escolhido), ou ainda, entre os laços de sangue e os do amor. No caso do Itatinga este contexto do distanciamento da família biológica diante da transformação corporal, ou do exercício da prostituição, contribui na produção desta noção comunitária de família, marcada pela descendência/filiação de uma mãe.

Mãezinha é a figura do afeto e aprendizado, mãe Juliana, por sua vez, como observado nos rituais de admiração e abordagem respeitosa e cautelosa na festa de seu 
aniversário, é uma figura disciplinar, mas também é o modelo a ser seguido em termos de sucesso e beleza:

Estava junto com um grupo de meninas dançando, tirando selfies, enfim, curtindo e fazendo a festa, quando chegou a aniversariante. Juliana foi cercada pelas suas filhas, cada uma com elogio, um abraço, beijo, gracejo, um presente em mãos .Esperei na fila para parabenizar Juliana e agradecer o convite para uma festa tão especial e divertida .Na festa que acontecia no amplo quintal de terra da Casa com muita fartura e participação, enrolamos brigadeiro e ajudamos no preparo da carne Havia ali uma atmosfera de família .Travestis da Casa, mulheres e crianças da vizinhança aproveitavam a festança .Allana veio perguntar toda preocupada se eu achava que seria a hora adequada para dar o presente da Juliana, que segurava carinhosamente nas mãos. (Diário de Campo, Junho de 2014).

Por fim, a residência coletiva é o elemento central na construção de um corpo transformado, pois através dela trocam-se informações para feminizar-se, incluindo o conhecimento sobre hormônios e tratamentos estéticos. Também é através da casa que estas têm acesso à colocação de silicone dos seios, pois Juliana e Alice organizam "caixas" individuais, com o dinheiro recolhido pelo trabalho ao longo do tempo, ou emprestam dinheiro para que as meninas realizem tal cirurgia.

\section{As educadoras militantes}

Como já mencionado, nossa entrada no bairro foi mediada por Denise, travesti militante moradora do Jardim Itatinga que é uma das intermediadoras centrais da rede que conecta o bairro e a sua movimentação política com movimentos sociais, como o LGBT e o feminista, e a academia ao recepcionar pesquisadores de diferentes áreas que possuem interesse em estudar o bairro e suas especificidades, seja do ponto de vista cultural, político, religioso ou até mesmo urbanístico.

Denise um referencial político para as travestis residentes no Jardim Itatinga, e até mesmo da cidade, sendo uma educadora em termos de mobilização ao engajar estas meninas em atividades de militância e em um discurso político especifico, tanto ao movimento de prostitutas, quanto a um segmento do movimento trans. Denise, a partir do início da década de 1990 diante da epidemia da AIDS, buscou parcerias para ajudar as 
amigas doentes que incluíam a Igreja Católica e o Estado no segmento de políticas públicas da Saúde e direitos humanos. Recuperando esta trajetória histórica afirmou em entrevista para Santos (2012, p.34):

Teve uma época que eu coloquei umas travestis pra morar comigo porque elas eram todas usuárias de drogas e portadoras do vírus HIV [...] Então isso começou em 91, 92, 93 mais ou menos quando eu aluguei uma casa e fui morar com essas travestis que eram portadoras do vírus HIV e fui cuidar delas. Foi quando começou a minha militância na questão da AIDS. Aí eu comecei a fazer treinamento, em 90, quando criou o Programa Municipal de DST/AIDS. Os primeiros funcionários que foram atuar nesse centro, eu fui fazer o treinamento junto com eles, aí foi quando eu me sensibilizei com a questão da AIDS.

Denise, além de acolher pessoas que tenham algum tipo de interesse no Itatinga, também estimula a participação das meninas nestas atividades visando que estas construam uma visão de mundo consciente de sua posição política e social. Por exemplo, no dia do evento sobre nome social, organizado pela defensoria pública e CEPROMM, ela estava na porta da ONG recepcionando e estimulando as meninas para que entrassem e participassem das discussões que seriam estabelecidas. Porém, não é somente para os eventos políticos que ela mobiliza a participação das travestis do bairro, mas também em performances, ensaios fotográficos e mesmo curso de inglês.

Denise, de certo modo, se relaciona com um segmento de mulheres trans que advoga pela defesa da categoria travesti, e que tem como uma das lideranças principais sua grande amiga Yara. Dentre os discursos deste segmento da luta pela visibilidade trans, a defesa da identidade travesti contrapõe-se à vertente que, ao reconhecer o aspecto histórico e cultural pejorativo que esta nomenclatura carrega, resolveu substituí-la por outro vocabulário como transexual, transgênero ou trans. Segundo Yara, é preciso lutar pelo respeito às travestis, pois mudar a nomenclatura não significa acabar na prática com a violência e o estigma que as acompanha. Em suas palavras ela não nasceu e nem quer se tornar uma mulher: "Eu sou travesti e é esta a minha identidade". Conforme Yara, que atualmente trabalha numa ONG que pretende combater a homofobia e promover valorização da diversidade, mas já ocupou funções com agente de políticas públicas no Estado, a travestilidade é a nomenclatura que mais se aproxima da sua experiência vivida, pois quebra o binarismo homem e mulher. Assim, ser travesti implica para ela uma 
resistência política, pois questiona a visão do senso comum sobre as pessoas trans, pois há uma negativa em se enquadrar dentro de categorias psiquiátricas. Também, não é impossível apagar, segundo ela, a história de meninas que morreram justamente por se assumirem travestis pela simples troca de uma classificação de identidade.

Yara nasceu em João Pessoa na Paraíba, e iniciou sua militância política no movimento LGBT há mais de 10 em Campinas, do qual Denise já participava. Formou-se em pedagogia e começou a atuar em ONGs e diversas políticas públicas em âmbito nacional, às vezes como militante, mas também como agente público. Dentre as experiências que marcaram sua trajetória e motivaram seu engajamento político está presente a violência, pois foi apedrejada na escola na sua adolescência e esfaqueada nas costas por um cliente. Para ela não é a fuga da travestilidade que evitaria a violência, pois como explicitou em uma de suas falas "isso seria o mesmo que negar a travestilidade, começar a me esconder e me camuflar, o que eu tenho que fazer é enfrentar”. Sendo muito amiga de Denise e de tantas outras moradoras do bairro, Yara é presença constante no Jardim Itatinga, seja no cotidiano, como em festas e eventos desta comunidade.

Essa proximidade com a militância é produtora de um discurso entre as meninas do orgulho travesti como muitas das vezes me afirmou Natalie, assim como outras meninas da casa, que têm como preferência serem reconhecidas deste modo. Nesta lógica, defendem que é preciso lutar pelo reconhecimento dos problemas que lhes são específicos e que enfrentam cotidianamente, como a violência transfóbica e o estigma, inclusive da prostituição. O papel das militantes entre as travestis do Jardim Itatinga é fundamental no aprendizado de um vocabulário político de reconhecimento e de estratégias de ação como passeatas, a Parada, participação em coletivos, intervenções artísticas, colaboração em trabalhos acadêmicos, organização e participação de palestras que versam sobre a visibilidade trans e assim por diante.

\section{Quem pode trans(itar) pela Escola? Narrando experiências escolares de trans-formação}


Quando iniciei minha pesquisa de mestrado tinha com clareza que uma das inspirações para tal empreendimento foi a amarga experiência de observar o abandono da escola de um Aluno cujo modo como expressa sua sexualidade e sua performance de gênero vejo como brilhante e criativo. Este aluno era Kiko, um adolescente que vez ou outra aparecia na escola trajadx com acessórios femininos e muita maquiagem. Porém, Kiko foi expulso do meu convívio escolar no dia que o pai de um garoto da mesma turma que ele, perseguiu-o nos arredores do escola com a finalidade de espancá-lo. Este mesmo homem, pelo que me foi relatado pelo coordenador na época, entrou na sala da direção gritando: "Meu filho não estuda com viado". Ainda muito assustada com esta experiência, encontrei Kiko, igualmente assustado, numa festa e ele me disse mostrando suas "garras" de unhas longas pintadas de preto: "Professora, se ele me pegasse eu o arranhava todo". Kiko foi transferido para o período da tarde e posteriormente abandonou a escola. Esta experiência, dentre outras, irei narrar brevemente neste tópico com a finalidade de compreender como as questões de gênero são vividas na escola, especialmente para quem cruza as barreiras das performances do masculino e do feminino. Seguindo esta lógica, início narrando uma brincadeira comum e até mesmo tradicional na ambiência escolar: o trote do contrário.

\section{a) $O$ trote do contrário}

Subindo as escadas na troca de aula, encontro um aluno que nunca tinha visto: um jovenzinho de roupas largas, boné e chinelo de dedos. Seria ele um aluno novo, um visitante? No topo das escadas, fui recepcionada por dois outros alunos trajados com roupas femininas e com muita maquiagem. Mais à frente, vejo no corredor um rapaz negro de vestidos longos e floridos e peruca loira, e outro também de saias longas e uma tiara rosa nos cabelos. Era o dia do trote do contrário, no qual os alunos do terceiro ano, por meio de um contrato prévio, trocam os papéis de gênero por um dia, representando o que imaginam ser a performance de gênero do "sexo oposto". O trote do contrário, deste modo, permite observar como os jovens desta faixa etária significam o gênero.

Meninos e meninas acabam construindo suas performances a partir de versões hiperbólicas do gênero, acionando símbolos estereotipados e tradicionais de como devem ser homens e mulheres. Os meninos fazem sua montagem tendo como referência 
geralmente uma mulher hiper sexualizada com saias ou shortinhos curtos, meias calças, lingeries à mostra, e muita maquiagem. Uma pequena parcela de moços mais tímidos, ou discretos, aciona uma mulher simples, quase idosa, quase assexual, com vestidos longos e florais. Enfim, os homens tendem representar o feminino no espectro da pureza e do perigo, da prostituta ou da mãe.

As meninas, por sua vez, se montam com base na sua grande maioria tendo como referência um "homem rústico", enfim, o estereótipo de homens das classes populares, dentre eles estão os pedreiros, os rappers, funkeiros e assim por diante. No Facebook, Amanda publicou uma foto do trote com as colegas acompanhada de uma letra de um clássico da música rap: "Negro Drama".

A brincadeira, portanto, reproduz posições tradicionais e estigmatizantes do gênero, não representando um questionamento da ordem social, mas apenas uma inversão que busca a reafirmação de valores pré-estabelecidos. A raça e a classe, por sua vez, também compõem a construção da fantasia, afinal tanto a mulher quanto o homem representados são das classes populares como a prostituta, a mãe dona de casa ou ainda, o trabalhador braçal.

Esta representação do gênero é, portanto, muito tradicional, sendo, como outros rituais de inversão, apenas uma interrupção do cotidiano que ao final retorna à ordem préestabelecida. Segundo Anne McClintock (2010, p.194), a mímica racial e o travestismo podem ser exemplos não apenas de subversão, mas também de subserviência ao contexto social de opressão.

Quando fuzileiros no exército dos Estados Unidos se enfeitam como drags ou pintam o rosto de preto, o poder branco não é necessariamente subvertido, nem a masculinidade é desarranjada. Talvez, se ao contrário, lésbicas no exército se transvestissem diariamente, os negros gays fizessem noturnamente uma desempenho voguing, o efeito quem sabe não fosse visto como tão hilário e inocente. (McClintock, 2010, p.113).

Portanto, o tradicional trote do contrário, realizado como ritual de encerramento desta etapa da vida social que é a escola, é uma experiência muito distinta do aluno que resolve utilizar saias, vestidos ou pintar as unhas no seu cotidiano, pois este provavelmente será vítima da incompreensão tanto de seus colegas quanto da instituição. Os alunos, no 
entanto, que se colocam numa posição de confronto em relação à matriz heterossexual enfrentam um cenário de homofobia e violência como veremos nos relatos dos percursos escolares relacionados a esta questão.

\section{b) A performance, o confronto e a violência}

Era dia do evento Miss e Mister Dom José, festa anual que escolhe os representantes da beleza e simpatia da escola. Gabriel agendou sua apresentação para o intervalo entre o desfile e a contagem de votos. Encontrei-o no caminho muito preocupado com a presença dos pais, pois estes, apesar de saberem que ele era homossexual, não aprovavam essas apresentações artísticas, porque segundo o pai ele tinha medo do filho ser ridicularizado ou sofrer agressões físicas. Um grupo de amigas também apareceu para dar apoio ao performer, segundo Melissa "nós protegemos o Gabriel”.

Melissa e seu grupo se posicionaram ao lado do palco e Gabriel iniciou sua apresentação. De início os pais não estavam na plateia, desapontados com desobediência do filho, porém com o entusiasmo audível do público eles apareceram e se acomodaram no pátio. Gabriel de camiseta e calças pretas fazia do modo mais fidedigno possível as coreografias das músicas de Lady Gaga, arrancando suspiros, gritos e aplausos. Gabriel era uma drag, porém de ordem diferente, pois não estava lá nem como um menino, mas também não era uma menina, afinal como ele me confessou: "sou queer".

Percebi que alguns alunos levantavam cadeiras e ameaçavam arremessar no palco, assim, eu e as "protetoras" de Gabriel fomos em direção destes garotos e requisitamos que estes saíssem do pátio. A arte de Gabriel é uma arte política, educativa, no sentido que a cada performance conquista um público justamente pela performance pública de sua homossexualidade, do confronto declarado que preocupou inclusive seus cuidadosos pais.

Outra pessoa que resolveu produzir um ato político nesta mesma lógica foi Jonhy, que na festa junina da escola foi travestido de mulher. Jonhy utilizava saltos enormes e vermelhos e um vestidinho curto de moça caipira. Naquela mesma semana, alguns alunos do Colégio Bandeirantes em São Paulo fizeram o mesmo, mas, ao contrário de Jonhy, foram duramente repreendidos, motivando um protesto com "saiaço" neste colégio. Nas festas juninas posteriores no Dom José multiplicaram-se drag's caipiras. 
Finalmente, presenciei nestes anos de trabalho vários episódios de violência motivada pela homofobia, dentre os quais o de Kiko. Kiko foi perseguido por um pai ao redor da escola que esbravejava não aceitar que seu filho estuda-se com "viado". Juliano, o filho deste pai, possuía uma relação de amizade próxima com Kiko. Encontrei recentemente Juliano, em um evento sobre ensino técnico no qual este se matriculou, e ele me disse que foi transferido de escola por seu pai, que justificara o fato dizendo que o diretor iria expulsá-lo mesmo pelas suas constantes brigas. Kiko não conseguiu terminar o Ensino Médio.

No próximo tópico apresento as experiências de Jaqueline, aluna transexual que se matriculou na escola onde trabalho, e de July, travesti moradora do pensionato de Alice, estudante do EJA (Educação de Jovens e Adultos), numa escola no centro de Campinas.

\section{A Educação para uma Trans-cidadania}

Na turba, ouve-se então, entre suspiros e exclamações transtornadas, um grito perfeitamente claro: "Lá está! O diabo!". O diabo, o diabo. Repetia enfileirado fazendo coro. E de fato, considerando aquele rosto ossudo, de traços nobres e bem desenhados, com seus olhos faiscantes, encontrava este grito, na imaginação das crianças uma espécie de justificação. Mal tinha desaparecido Alexina, foi vista Henriette, que num primeiro momento de surpresa tinha se refugiado atrás de Madame; olhou hesitante em torno de si, tomou súbito a mesma resolução, abriu caminho e saiu como um furacão. "Lá está sua noiva", gritou uma voz. O grito correu de boca em boca, sobretudo entre as pequenas como uma coisa natural: "O diabo e sua noiva! O diabo e sua noiva". (Pazzina apud Foucault, 1982, p.158).

Herculine Barbin era professora primária em um internato de meninas quando foi identificada a sua intersexualidade, sendo obrigada a assumir seu sexo verdadeiro como masculino acabou se suicidando e deixando suas memórias relatadas em um diário. A autobiografia foi publicada por Foucault (1982) conjuntamente com os dossiês médicos e jurídicos sobre o caso, bem como um romance escrito por Oscar Pazzina na época com base na história de Herculine. Poderíamos no primeiro momento, deslocando os objetivos de Foucault ao analisar a história de Alexina, conjecturar que o problema de Herculine Barbin talvez não tenha sido primordialmente a ambiguidade sexual, mas o fato desta 
ambiguidade ter sido descoberta na ambiência escolar.

A escola na trajetória de Herculine ocupou um papel central na construção de sua subjetividade, pois através dela obteve educação adequada para se tornar exímia escritora deixando um relato autobiográfico complexo e refinado. Assim, o diário de Herculine é uma confissão: "É o diário, ou melhor, as memórias deixadas por um desses indivíduos a quem a medicina e a justiça do século XIX perguntavam obstinadamente qual era a verdadeira identidade sexual" (1982, p. 4). De acordo com Foucault (1982) a confissão se direciona a um interlocutor que avalia para julgar, punir, perdoar, consolar e reconciliar. Os médicos e os homens de lei foram os interlocutores desta confissão que interrogaram Herculine para estabelecer sua "verdadeira" identidade sexual, determinando legalmente seu estado civil.

A partir do século XVIII cada indivíduo deverá ter um sexo, e no caso dos hermafroditas seria necessário aos médicos determinarem o verdadeiro sexo. Na época de Herculine, consolidava-se esta necessidade dos saberes em classificar os diferentes anormais como problema da espécie em termos de anomalias e perversões (Foucault, 1982, p. 5).

Porém, Barbin escreve suas memórias no sentido de justificar seu sexo demarcado pelo médico que a examinou, sendo que sua narrativa escapa a simplificações em termos de identificação, seja com um indivíduo homossexual ou bissexual. Afinal, ao escrever, Herculine tem para si um sexo incerto que a permitia experimentar sem o constrangimento de um sexo único que posteriormente a impuseram, sendo assim, ela traz à tona a questão se era realmente necessário demarcar um sexo do modo como estabelecia o discurso médico e jurídico do século XIX.

O que nos interessa na história de Herculine é a inspiração que esta nos oferece para analisar as condições de acesso das pessoas que transitam entre as performances de gênero à educação. Assim, tive a sensação de déjà vu na ocasião da matrícula de uma aluna transexual na escola em que trabalho, pois, tal como na história de Herculine, os constrangimentos e rumores também fizeram parte do breve período que a adolescente em questão permaneceu na escola.

Jaqueline é uma menina de cerca de 19 anos, portanto, um pouco mais velha que seus colegas de turma do primeiro ano do Ensino Médio. Possuindo longos cabelos negros 
e com um corpo já completamente transformado pela hormonoterapia, contando inclusive com silicone nos seios, passou por várias semanas sem chamar atenção para sua identidade de gênero na escola, pois seu nome social foi adicionado à lista de presença logo no ato da matrícula. Porém, no dia que os alunos descobriram que Jaqueline era trans despertou-se, além da curiosidade, toda sorte de preconceitos quanto ao fato, de modo que numa classe tive que repreender a turma, pois um aluno fizera piadas sobre a garota, chamando-a de "travecão". Este trecho do meu diário descreve esta experiência da matrícula da aluna transexual na escola:

Dom José, escola onde trabalho, está passando por um processo muito interessante. Jaqueline, uma menina transexual, retornou à escola no primeiro ano do Ensino Médio a fim de terminar os estudos, interrompidos há uns anos atrás justamente pela questão da transfobia. Não dou aulas para a sala dela. Porém, desde o primeiro dia, acompanho a vida escolar da garota e sou interpelada cotidianamente por colegas que se sentem incomodados com as atitudes de alguns alunos frente à menina. Certa vez a professora de Educação Física me procurou para desabafar sobre a intolerância das meninas do terceiro ano, que afirmaram não querer a presença de Jaqueline no banheiro feminino, pois consideravam errado um "homem" frequentar este espaço. A professora de química observou que no intervalo ela era muito assediada pela curiosidade dos alunos, que a abordavam constantemente para que ela falasse de si.

Esta professora então teve a ideia de abordarmos o tema na reunião de planejamento anual. Procuramos a direção que prontamente autorizou a minha fala. Hoje, chamada por ela já no final da reunião coloquei dentre outras coisas a importância da legislação do nome social. Comecei a minha fala expondo minha pesquisa, meu campo e do curso de inglês para travestis e prostitutas. Falei da dificuldade em terminar o ensino básico das travestis que conheço, e pontuei o caso de July que somente agora estava se alfabetizando. Portanto, informei a importância de acolher a aluna, pois estaríamos assim sendo referência no município, caso esta completasse em boas condições o Ensino Médio [...].

Ao final da conversa, totalmente apoiada pela diretora, que ao meu lado reforçava tudo aquilo que eu dizia, uma professora expôs em relação ao banheiro e da resistência de algumas meninas em aceitar a presença neste ambiente de Jaqueline. Disse a ela que a militância política trans é muito forte e que esta vem conseguindo reconhecimento para suas questões e que teríamos que informar as alunas sobre os problemas inclusive judiciais deste tipo de atitude. Neste sentido, informei que recentemente uma defensora pública, conhecida minha, havia dado um curso de direitos humanos para policiais que impediram as travestis de entrar no banheiro público, sendo o curso uma das penalidades estabelecidas pelo juiz que julgou o processo que estas abriram contra a PM.

Sobre este momento encontrei, ainda, o registro da seguinte reflexão: 
[...] Uma escola é a ambiência da fofoca e dos boatos por excelência, Herculine Barbin que o diga, mas é preciso mudar esta instituição do confinamento e disciplinarização já que esta deve assumir em uma sociedade democrática a identidade de formadora de cidadãos. Que saíamos do século XIX. (Caderno de campo, 06 de Março de 2014).

Jaqueline parou de estudar uma semana depois da minha conversa com os professores. Provavelmente as condições de vivência tornaram-se insuportáveis, porém ela nos justificou esta escolha afirmando que estava muito cansada por trabalhar como vendedora de loja e estudar ao mesmo tempo. Entre os alunos, no entanto, circulavam boatos fantasiosos que ela havia dado uma entrevista na televisão local afirmando que sofrera transfobia na escola. Procurei a direção na época e soube que a questão da entrevista não passava de um imenso boato, dentre os vários que sempre surgiu sobre a vida da adolescente no ambiente escolar, inclusive alguns maldosos e menos inocente do que este.

Refletir sobre o tema da educação para as travestis e transexuais não era o objetivo primeiro desta pesquisa, porém tornou-se uma necessidade diante do fato de nossa entrada a campo ter-se dado pelo viés da educação, um curso de inglês e pela constatação de que a maioria das meninas do pensionato de Alice não terminou a educação básica. Isto inclusive foi uma das primeiras dificuldades pedagógicas na elaboração dos planos de aula de inglês, afinal dentre a diversidade de alunas que tínhamos, algumas não eram alfabetizadas, como no caso de Katy, que abandonou o curso provavelmente por esta dificuldade.

Katy, uma menina trans e negra de pouco mais de 20 anos, mostrava-se muito inquieta nas aulas, distraindo-se muita das vezes com outras tarefas, como verificar o que se passava no smartphone. Porém, quando chegou finalmente a aula que corrigimos pela primeira vez as tarefas de “homework", percebemos que Katy não era alfabetizada completamente no português, e possivelmente entendia muito pouco o que acontecia nas aulas em termos do aprendizado do inglês. No último dia que foi à aula, Katy estava inquieta, queria saber como se escrevia "Eu sou uma cidadã", em inglês, para escrever em seu caderno. Ela demorou em copiar da lousa, enquanto a aula seguia em ritmo frenético diante do engajamento de um grupo de alunas que se adiantava às outras colegas por ter facilidade no aprendizado, já que possuíam um capital cultural que permitia esta habilidade maior em aprender. "I am a citizen”, esta construção de frase proposta pela aluna é muito interessante, pois me questiono até hoje porque escolher esta expressão dentre tantas outras 
disponíveis. Aprender inglês para Katy era fundamental na construção de sua cidadania? Ela escutara a frase em outro contexto e talvez quisesse perseguir e aprender mais este conceito? Não tive tempo de perguntar, pois uma semana depois desta aula, Katy havia se mudado do bairro.

As alunas que permaneceram nas aulas por um período maior de tempo eram as que conseguiam acompanhar o aprendizado de uma língua estrangeira ao possuir certo capital cultural, tendo conhecimentos prévios que as ajudavam nesta tarefa. Jasmine cursou até o segundo ano do Ensino Médio, enquanto Natalie terminou o Ensino Fundamental. Ambas conseguiram um bom aproveitamento em termos de aprendizagem e me relataram um bom relacionamento com a escola quanto ainda estudavam. Natalie, uma jovem de 25 anos, quando parou de estudar ainda não tinha se transformado. Jasmine, uma moça de 24, afirmou, quando perguntei sobre as suas experiências escolares, que apesar das implicâncias dos amigos quanto ao seu comportamento, tinha uma boa convivência na escola, na qual os professores utilizavam seu nome social.

No entanto, a maioria das pessoas do pensionato não possui o Ensino Básico completo e soube apenas de uma menina que tinha curso superior. Deste modo, podemos estabelecer como hipótese que isto se deva à questão da intolerância da ambiência escolar em acolher travestis e transexuais de uma forma inclusiva e cidadã. Perguntava sobre a escolaridade quase todas as vezes que estabelecia uma interação com alguma menina da casa, e tinha certa liberdade por começar o diálogo por este tipo de assunto, afinal era reconhecida no pensionato e bairro como a teacher ou professora de escola. Portanto, este dado é resultado de interações em que elas me contavam até quando haviam frequantado a escola, quais as disciplinas que mais gostavam e os professores que ficaram na lembrança. Por meio destes relatos, soube que Jasmine foi um das poucas que frequentou a escola já transformada, uma vez que maioria ainda era um "boyzinho" nesta fase da vida, mantendo memórias felizes sobre esta fase, mas também memórias incômodas relativas à homofobia.

Conheci July em uma destas interações. Ela tinha cerca de 30 anos, tem pele branca, olhos verdes e um cabelo bem encaracolado, tingido de louro e quase sempre alisado pela “chapinha”. Enquanto, ajustava a projeção da tela na parede, ela se aproximou e leu uma frase qualquer que descrevia um arquivo guardado em meu notebook. Ela me contou que estava aprendendo ler e que admirava muito os professores alfabetizadores, pois considera 
a tarefa essencial de ensinar as pessoas a ler uma coisa maravilhosa e difícil. July me contou um pouco sobre sua professora, que muitas vezes a defendeu frente à turma até que estes a aceitaram e começaram a respeitá-la. Relatou também que a diretora da escola já fora à sua sala falar justamente sobre esta questão do respeito às pessoas trans. Confessou-me neste dia que gostava muito das aulas de arte e que um dia mostraria seus desenhos para mim, o que fez posteriormente quando lhe entreguei um kit de lápis de cor e réguas como presente.

July, toda vez que me via, buscava seus cadernos para que visse as lições. Possuía cadernos muito organizados e mantinha sempre suas tarefas em dia, tendo várias menções de "Parabéns", "Ótimo", "Lindo", dentre outros elogios feitas pela sua professora. Certa vez, disse-me que agora adorava a escola, mas na época que era criança não gostava muito, porque seus colegas não a entendiam bem. Relatou em outro momento que foi matriculada numa escola para alunos como necessidades especiais, e que ela não era uma criança especial e por isto não se sentia muito bem com isto. A experiência de July é exemplar deste afastamento da escola em razão da transfobia, porém esta enfrenta estas condições com muita coragem e perspicácia, como ficou evidente em uma dessas interações:

July chegou da escola e se juntou a nós. Mostrou-me o caderno, e disse estar adorando a escola. No início teve muito preconceito, mas a diretora conversou com seus colegas de turma, e hoje tudo está bem de acordo com ela. Porém tem um cara que chegou hoje e a chamou de "viado", sem ter intimidades pra isso. Ficou chateada com o caso. Contou um episódio que acontecera estes dias com ela, no Terminal Central, lugar que ela odeia ter que passar para ir às aulas dado o preconceito dos camelôs, que sempre a abordam com comentários ofensivos ou maliciosos. Neste dia um moço a chamou de "travecão" e ela falou com a patroa dele, dona do estande, sobre o ocorrido, e esta o ameaçou de dispensá-lo caso abordasse a travesti deste modo novamente.

Mostrou-me seu caderno de anotações. Ela está se alfabetizando. Peguei um livro infantil da minha sacola e ela leu um parágrafo com dificuldade. Dei este livro e um caderno para ela, que ficou muito feliz. (Caderno de campo, 18 /02/2014).

A questão do acesso à educação é central para uma vivência cidadã, como exposto por Amanda, travesti que chegou ao pensionato recentemente e acompanhou uma de nossas aulas de inglês. Esta havia chegado deportada da Europa e relatou sua experiência de constrangimento em um aeroporto da Itália ao não conseguir se comunicar "pelo menos em inglês" com a polícia. Convidei-a para participar das aulas e ofereci um caderno para 
que fizesse anotações, no entanto, esta o recusou, afirmando que neste momento iria apenas observar e guardar na cabeça. Ela não frequentou as aulas subsequentes, e Letizia levantou a hipótese de que eu a havia constrangido, pois frente à negativa do caderno ficou evidente a dificuldade desta em escrever, sendo provavelmente não alfabetizada.

Seguindo esta demanda de acesso à educação pelas pessoas trans, uma conquista atual foi à aprovação da norma no Estado de São Paulo que garante a transexuais e travestis, matriculadas em rede pública ou particular de ensino o direito de serem chamadas pelo nome social nas escolas. Esta norma foi aprovada pelo CEE (Conselho Estadual de Educação) em meados de Maio de 2014. No entanto, o decreto estadual 55.5588/2010 já garantia o tratamento pelo nome social das pessoas transexuais e travestis nos órgãos públicos do Estado de São Paulo.

Neste mesmo sentido, foi publicado no Diário Oficial da União em Março de 2015 a resolução que visa garantir condições de acesso e permanência de pessoas travestis e transexuais - "e todas aquelas que tenham sua identidade de gênero não reconhecida em diferentes espaços sociais" - nas instituições de ensino. De acordo com os artigos desta resolução, as escolas e universidades, públicas e particulares, devem garantir o uso de banheiros, vestiários e demais espaços segregados de acordo com a identidade de gênero de cada sujeito. Além disso, o campo "nome social" deve ser inserido nos formulários e sistemas de informação utilizados nos procedimentos de seleção, inscrição, matrícula, registro de frequência, avaliação e similares.

Conforme os dados apresentados pela Secretaria Estadual de Educação ${ }^{11}$ de São Paulo, ocorreu um crescimento nos pedidos para registro escolar de nome social de 44 para 127 solicitações de março a junho deste ano letivo de 2015, ressaltando que na rede pública estadual estão matriculados cerca de 4 milhões de alunos. Esta mesma Secretaria registrou que $86 \%$ dos que requisitaram o nome social são mulheres transexuais e travestis, sendo que a maioria desses estudantes são maiores de 18 anos (60\%), estudam no período noturno 68 \% e, por fim, $44 \%$ estão na Educação para Jovens e Adultos e 26\% cursam o Ensino Médio regular.

\footnotetext{
11 Ver http://g1.globo.com/educacao/noticia/2015/06/uso-de-nome-social-por-transexuais-triplica-emescolas-diz-secretaria.html.
} 
No entanto, no Plano Nacional de Educação ${ }^{12}$, a garantia da igualdade de gênero e orientação sexual foi retirada do texto aprovado pelo Congresso Nacional em $2014^{13}$, sendo tal proposta novamente recusada em grande parte dos Planos Municipais e Estaduais de Educação ${ }^{14}$, neste ano de 2015, pelos seus respectivos legislativos diante de forte lobby de setores religiosos e conservadores que possuem enorme influência na esfera da política institucional.

No dia 29 de Janeiro de 2015, o Dia Nacional da Visibilidade Trans, a prefeitura de São Paulo lançou o programa Trans-Cidadania ${ }^{15}$ que oferecerá bolsa auxílio de R $\$ 840,00$ a travestis e transexuais que desejam estudar. No início, serão oferecidas 100 vagas a pessoas interessadas e o benefício será dado para que as travestis e transexuais se qualificarem pelo Programa Nacional de Acesso ao Ensino Técnico e Emprego (Pronatec) do Governo Federal. Segundo os dados fornecidos pela Secretaria de Direitos Humanos do munícipio de São Paulo, 61\% das travestis/transexuais não possuem Ensino Médio, 50\% não têm moradia adequada e $80 \%$ não têm qualquer tipo de renda fixa na cidade de São Paulo.

Também quem participar do projeto terá direito a utilizar o nome social na rede municipal de ensino, nos boletins, livros, registro escolares, certificados e diplomas. Porém, o Programa, neste primeiro momento, tem como prioridade o atendimento de pessoas em situação de rua, que não tenham concluído o Ensino Médio ou com Ensino Fundamental incompleto, sendo que a pessoa que se beneficiar não pode ter tido registro na carteira de trabalho nos últimos três meses.

Finalmente, é interessante ressaltar o trabalho de Mariana Reidel (2013), professora transexual de Educação Básica nas disciplinas de arte e cidadania e pesquisadora em educação, que na sua dissertação descreve a trajetória de professoras transexuais e travestis, bem como seu projeto de ação pedagógica na unidade escolar em que trabalha, que tinha como finalidade o combate ao preconceito, à homofobia e à violência. Neste projeto em especial foi utilizada uma metodologia de ensino/aprendizagem que tomava como ponto

\footnotetext{
${ }^{12}$ Ver http://www.planalto.gov.br/ccivil_03/_Ato2011-2014/2014/Lei/L13005.htm.

${ }^{13} \mathrm{Ver}$ http://www.redebrasilatual.com.br/educacao/2014/04/lobby-conservador-retira-igualdade-de-generodo-plano-nacional-de-educacao-5214.html.

${ }^{14}$ Ver http://www1.folha.uol.com.br/educacao/2015/06/1647528-por-pressao-planos-de-educacao-de-8estados-excluem-ideologia-de-genero.shtml.

${ }^{15}$ Ver http://www.pt.org.br/haddad-lanca-transcidadania/.
} 
de partida analítico a realidade social do aluno, obtendo um relativo sucesso com a diminuição de episódios de violência nesse cotidiano escolar. Segundo o depoimento das professoras entrevistadas por Mariana Reidel, existe uma percepção de que a presença destas nas unidades escolares acaba por transformá-las também em mediadoras nos conflitos existentes em termos de preconceito. Esta presença mediadora inclusive melhorou a recepção às alunas transexuais e travestis. A autora denomina essas experiências educativas de ação combativa em relação ao preconceito, especialmente a homofobia e a transfobia, como uma pedagogia do salto alto, que pode ser realizada não apenas por professores transexuais, mas por todos que se mobilizam diante de tais questões.

\section{Algumas reflexões finais}

As vivências de gênero na ambiência escolar são marcantes na trajetória de muitos indivíduos dadas as consequências psicológicas e sociais que este período da vida evoca. Os corpos, as corporalidades, os trejeitos, a linguagem dos vários segmentos sociais se condensam nas figuras adolescentes que circulam por este território, segmentos estes que podem ser mais homogêneos em certos contextos sociais de classe, por exemplo, ou heterogêneos em outros. Observo que este território é percebido pelos estudantes como espaço social de afirmação de valores, trabalhando em prol da conservação da ordem ou para transformar suas trajetórias e o contexto social que os cerca.

Sendo assim, muitos querem, como afirmou um de meus alunos, "fazer a revolução, professora", ou fantasiam, como apareceu na fala de outro, "estourar os miolos do Alckmin" na terra arrasada de Pinheirinho. Porém, a simplicidade, a revolta e a inocência destes alunos em suas escolhas políticas produzem muita das vezes uma incoerência discursiva, dado que em certas questões emergem numa lógica conservadora, enquanto outras seguem uma militância progressista. No entanto, como seres sociais advindo de múltiplos contextos - sejam religiosos, de classe, políticos e assim por diante - muitos desses posicionamentos são trazidos de "casa", mesmo quando se elaboram como uma forma de oposição à autoridade familiar. Em resumo, na escola não circulam apenas professores de jaleco e teoremas de matemáticos, mas também valores políticos, religiosos, estéticos e assim por diante. Em relação ao gênero, a escola é um caldeirão fervente de 
ideias, valores e práticas que conformam um espaço da socialização e da política de gênero e sexualidade.

Guacira Lopes Louro descreve este papel da instituição escolar no que tange a uma pedagogia da sexualidade, na qual a escola formata as expectativas sociais relacionadas às performances de gênero normativas por meio da disciplina dos corpos e dos discursos. Assim, os corpos são ensinados disciplinados, medidos, avaliados, examinados, aprovados, categorizados, magoados, coagidos, consentidos no interior do contexto escolar, e a escola estabelece marcas fundamentais na nossa construção de identidades sociais, inclusive nossas identidades de gênero e sexualidade (Lopes Louro, 2001, p.19). Um corpo escolarizado tem a habilidade de expressar gestos de interesse e atenção mesmo que falsos, como o de ficar sentado por muitas horas, permanecer em silêncio, falar de um determinado modo ou usar o tempo e o espaço de uma forma específica. Dentro dessa mesma lógica, a escola educa os corpos para serem homens e mulheres de verdade, de acordo com a concepção hegemônica de uma época ou sociedade (Ibidem, p.18).

Porém, o cinema, a televisão, as revistas e a publicidade também exercem uma forma de pedagogia do corpo ideal desejável, sendo concorrentes à pedagogia escolar. Aliás, múltiplas instâncias (família, escola, mídia, igreja, lei etc.) estão envolvidas na pedagogia do corpo, mas isso não significa que as identidades são construídas de modo passivo, afinal está se completa através do autodisciplinamento e autogoverno que os indivíduos exercem sobre si mesmos (Ibidem, p.25).

A suposta dessexualização está presente no espaço escolar, nas regras da instituição escolar em si, mas também na forma como se apresenta a corporalidade de professoras e professores (Ibidem, p.21). Esta presunção de instituição dessexualizada acaba por marcar determinados indivíduos que não se adequam a esse esquadrinhamento como sendo corrompidos e desajustados, sensualizando-os (Ibidem, p.26). Deste modo, modelar "homens e mulheres de verdade" constitui um desafio à pedagogia escolar dos corpos, pois é necessário que estes sejam incentivados a uma sexualidade dita normal, simultaneamente contida. A homofobia, muitas vezes, acaba sendo estimulada nesta ambiência pautada na demarcação de um outro visto como corrompido sendo uma postura, como observado pela autora:

Consentida e ensinada na escola a homofobia expressa-se pelo desprezo, 
pelo afastamento, pela imposição do ridículo. Como se a homossexualidade fosse contagiosa, cria-se uma grande resistência em demonstrar simpatia para com sujeitos homossexuais, a aproximação pode ser interpretada como uma adesão ao tal prática ou identidade. (Lopes Louro, 2001, p.29).

Finalmente, Lopes Louro pontua que fazer a história ou as histórias da pedagogia da sexualidade nos torna capaz de reinventa-la e torná-la plural, portanto a escola pode e deve ser transformada (2001, p.33).

As sociabilidades de gênero, neste contexto, são muito diversas e tendem cada vez mais à multiplicação de identidades e expressões em razão da crescente politização da questão. A escola, portanto, segundo uma abordagem granscimiana desta instituição como aparelho de hegemonia, também é o palco privilegiado de se fazer a política do gênero, seja para os feminismos, para o movimento LGBT, as novas famílias, as igrejas, os grupos conservadores e assim por diante.

Há muito que ser relatado por mim sobre esta ambiência, como por exemplo, meu incômodo ao presenciar a reprodução do machismo em discursos e práticas no cotidiano das aulas e da escola por intermédio dos regramentos que regulam esta instituição disciplinar. Seguem abaixo minhas observações de uma aula sobre gênero que ocorreu em uma de minhas turmas de Ensino Médio:

Não sei exatamente quando a aula começou a caminhar para um entusiasmando debate, porém minha ansiedade era crescente dada a possibilidade de aquilo não acabar bem. Estava falando sobre os papéis de gênero, o que a sociedade impõe como coisa de menino ou de menina, quando escutei a famigerada frase: "Mulher tem que se dar o respeito". "Mas o que é ser mulher de respeito?", questionei aos meus interlocutores e fui bombardeado com discursos do tipo "mulher de roupa curta e que sai por aí bêbada está pedindo", "professora, dependendo do jeito da menina ela quer que mexa com ela na rua". Pensei comigo, mulher de respeito para eles não seria aquela que expressa o seu desejo pelo sexo oposto e perguntei a sala se mulher não poderia gostar de sexo, recebi olhares de satisfação e indignação. Questionei o que seria "mexer" com mulher na rua? Gracejos, assédio, violência física? Disse à sala que imaginasse que foram abordados sozinhos por um estranho na rua e de que sensação isso provocaria, nesta lógica muitos declararam o constrangimento, porém alguns continuavam no discurso da culpa da vítima ou da inocência de certas práticas como "mexer" com mulher. No ápice da discussão, escrevi na lousa "estupro é diferente de sexo consensual", a sala silenciou-se pelo choque, mas também pelo óbvio. Exposta a crueza da violência, era impossível argumentar em favor dos 
discursos que a suportam. (Anotações de aula/ Caderno de campo, Outubro, 2014).

As regras disciplinares em relação à indumentária na escola também possuem alvos e objetivos específicos. O corpo da mulher é a todo o momento vigiado por esse conjunto de regramentos que, como me afirmou um profissional da área de educação, serve para proteger as meninas de possíveis abordagens violentas do sexo oposto. Mas os meninos não devem ser educados a respeitar os corpos femininos? Regras como estas não legitimam discursos como o da culpabilidade da vítima? Estas questões aparecem no meu cotidiano escolar e sinto um enorme desconforto acerca destes regramentos da indumentária feminina presentes na escola. Estes procedimentos sempre foram incômodos para mim, uma educadora mulher, como se segue abaixo em minhas anotações de aula:

Não sei se por uma interpretação equivocada do regimento escolar, mas o fato, que tanto eu quanto as jovens mulheres que assistiam a minha aula, nos constrangemos. Uma funcionária interrompeu minha aula e pediu que apenas as meninas se levantassem para verificar o comprimento das roupas. Para amenizar a situação pedi também que um garoto de regata bem cavada também levantasse. Nenhuma menina foi repreendida, pois estavam trajadas de acordo com as regras, porém também não foi chamada a atenção do menino. (Diário de campo, anotações de aula, Fevereiro, 2013).

A transgressão dos padrões de indumentária de gênero é produtora de muitas controvérsias, no entanto, também tem sido nos últimos anos uma fronteira política tensionada pela ação de estudantes e pais que defendem uma escola mais democrática em relação às expressões de gênero. Por exemplo, os alunos do colégio Bandeirantes, tradicional escola paulistana, em meados de 2013, não conformados com a atitude da direção que suspendera um garoto que havia ido de saia à festa junina protestaram com a organização de um "saiaço" na escola. Seguiram-se "saiaços" em várias outras escolas, tendo ocorrido inclusive um destes eventos na Universidade de São Paulo. Seguem trechos de reportagens sobre os "saiaços".

Estudantes do ensino médio do Colégio Bandeirantes, de São Paulo, foram para aula nesta segunda-feira (10) vestindo saia, inclusive os meninos, em protesto contra um incidente envolvendo dois alunos que usaram saia na semana passada. Na última sexta-feira (7), um dos jovens foi retirado da aula por estar de saia. A mobilização foi feita nas redes sociais e envolveu até ex-alunos de um dos mais tradicionais colégios de 
São Paulo. A direção do colégio permitiu que os estudantes assistissem às aulas de saia e disse que apesar de os Bandeirantes nunca em sua história ter uniforme escolar, os alunos devem seguir um código 'informal' de vestimentas. 10/06/2013, Portal G1. http://g1.globo.com/educacao/noticia/2013/06/alunos-de-colegio-de-spfazem-saiaco-em-protesto-contra-direcao.html

Alunos do Colégio Pedro II, no Rio de Janeiro, vestiram saias em protesto contra discriminação sofrida por uma colega. A foto do "saiaço", publicada na comunidade "Os Cariocas" do Facebook vem sendo curtida e apoiada. A vítima seria uma aluna transgênero. A adolescente nasceu com o órgão genital masculino e, por isso, foi proibida pela direção da escola de usar a peça, comum ao vestuário feminino. A aluna foi barrada no colégio no dia 23 de agosto, conforme o jornal O Dia. 10/09/14, O Tempo.

http://www.otempo.com.br/capa/brasil/alunos-fazem-saia\%C3\%A7oem-apoio-\%C3\%A0-colega-transg\%C3\%AAnero-1.913819

Estudantes da Universidade de São Paulo promoveram nesta quinta-feira (16) o ato "USP de saia" em apoio ao estudante Vitor Pereira, que foi ofendido pela internet depois de vestir saia para ir à aula no campus da USP na Zona Leste. Pelas ruas do campus da Cidade Universitária, na Zona Oeste de São Paulo, foi possível encontrar homens usando saia, top e até vestido e mulheres de gravata. Teve até "pebolim de saias". O ato também teve adesão nos outros campi da USP, como o da Faculdade de Direito do Largo São Francisco, USP Leste, Ribeirão Preto e São Carlos. 16/05/2013. Portal G1.

http://g1.globo.com/educacao/noticia/2013/05/ato-na-usp-reune-alunasde-gravata-rapazes-de-top-e-pebolim-de-saias.html

Outro exemplo de visibilidade foi o de Romeo Clark, aluno britânico de apenas cinco anos, que se tornou mundialmente famoso quando sua mãe denunciou a instituição de ensino que o garoto frequentava por não autorizar a presença do garoto em suas dependências trajando suas roupas preferidas, uma coleção de mais de 100 vestidos, que segundo ele disse ao tabloide Daily Mirror "são fofos, bonitos e tem muito brilho". 


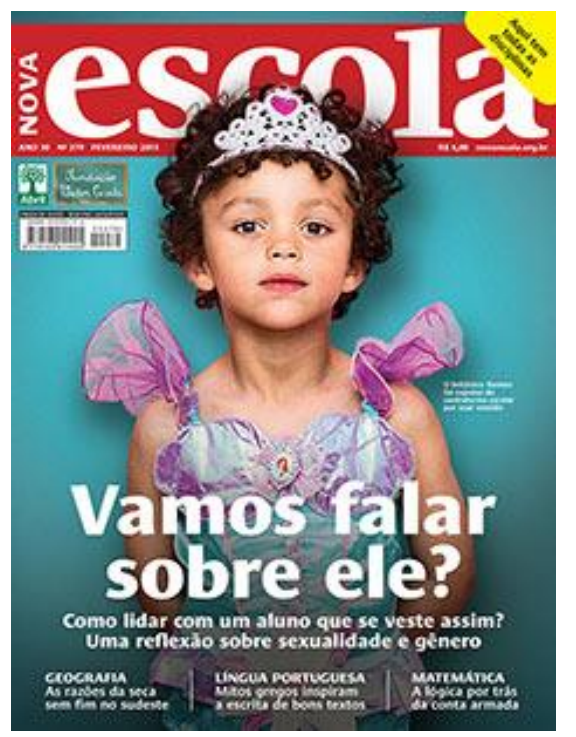

No capítulo seguinte apresento o tema das complexas classificações trans e de como estas são acionadas no cotidiano da residência coletiva de Juliana, pontuando como este contexto específico, mediado por uma percepção política da educação militante e situada numa região demarcada como território da prostituição, constrói os modos pelos quais as pessoas reconhecem a si mesmas e as outras. 


\section{CAPÍTULO 4. Classificações trans: "como se diz 'travecão' em inglês"?}

Revisamos as apresentações aprendidas na aula anterior, estudamos os verbos to be, e posteriormente vimos um vídeo sobre as letras do alfabeto. Assim o exercício do dia foi o do "spell your name". Nicole soletrou seu nome primeiro. Jade posteriormente. Os nomes que produziram controvérsias foram os de Katy, Nataly e Lu. Lu, que é chamada pelas colegas pelo artigo feminino soletrou seu nome L-U-C-I-A-N-O, mas nos proibiu de repetir seu nome de "menino". Katy soletrou com dificuldade seu nome, enquanto as colegas palpitavam se era escrito deste ou daquele modo. Nataly, com y, também foi vítima das intromissões das colegas, afinal segundo Tatiane não existe Nataly com y. Tatiane, por fim, disse que seu nome era de pobre, sem os Y's.

A controvérsia que presenciamos em relação aos nomes trans deve-se ao fato dele ter sido autoatribuído. Também são nomes estrangeiros, o que denota uma glamorização daquilo que é de fora e potencialmente branco. E é por isso que Tatiane afirmara ter nome de pobre.

Quase ao final da aula uma das alunas disparou "como se fala travecão em inglês?". Travecão é um xingamento direcionada a travestis mais velhas, mas também travestis em geral, hostilizadas em seu cotidiano. Pontuei que era um xingamento e não sabia o equivalente em inglês, porém para travestis e transexuais poderia se usar "transgender". Observei que transexuais aqui são vistas pelos médicos como as operadas, mas nos EUA serve também para as que não é. Travestite, segundo esta mesma tradição médica é aquele que se veste eventualmente de mulher. Acho que ninguém entendeu muito bem, Alice chegou e fez graça com a nossa confusão classificatória, afirmando que era "todo mundo menina, girl".

Enfim, esta aula foi a da classificação, da curiosidade dos nomes, demonstrando essa dificuldade no aprendizado de uma língua, pois se comunicam universos culturais distintos, seja a classificação americana e brasileira, ou a classificação médica e o uso social destas classificações. (Diário de campo, 26/10/2013).

A aula descrita acima foi muito produtiva, não no sentido da aprendizagem das alunas em questão, pois estas saíram confusas quanto àquilo que desejavam aprender, ou seja, comunicar o vocabulário brasileiro da travestilidade com termos em inglês. No entanto, a produtividade da aula esteve em levantar questões fundamentais em termos de classificações, inclusive a que diz respeito a identidade e a nomeação, bem como a conexão dos termos em questão com os marcadores sociais da diferença em relação a raça, gênero e classe social.

Diante da questão da aluna lembrei-me da diferença classificatória apontada por 
Jorge Leite Jr.(2008) entre o Brasil e países estrangeiros em relação aos termos travestis e transexuais. No Brasil, existe uma diferença classificatória em relação aos manuais internacionais de medicina e psiquiatria para descrever a condição trans, pois o que em outros contextos, como os de língua inglesa, seria denominado de transexual (secundário nos manuais) é classificado aqui como travesti. Esta é reconhecida pela cultura popular e de massas como aquela que adota o gênero feminino, sofre intervenções hormonais e cirúrgicas para feminizar seu corpo, adota as vestimentas e nomes femininos e não deseja a cirurgia de transgenitalização.

O travestismo transvéstico do Manual Diagnóstico e Estatístico de Transtornos Mentais (DSM) e o travestismo fetichista do Código Internacional de Doenças (CID) podem ser relacionados no contexto brasileiro com os chamados "crossdressers", sendo um grupo que independente da orientação sexual realizam uma montagem do feminino durante algumas horas do dia. Aliás, uma parte considerável de nossas interlocutoras consideram esta montagem eventual dos indivíduos que se auto identificam como "crossdressers" uma "coisa ruim", um comportamento de "loucura".

Diante da dificuldade em expor para o grupo de alunas esta diferença, lembrei-me da categoria guarda-chuva "transgender". Mas mesmo esta não respondia a questão da aluna, uma vez que ela procurava o equivalente a um xingamento, que elas trocam entre si e são interpeladas por estranhos no cotidiano. Não era possível no espaço de uma aula refletir acerca desta questão, assim sendo, "Mãezinha" finalizou "somos todos meninas, girls".

Por outro lado, cogitei a possibilidade de tentar fazer as correspondências entre os termos em uma aula especifica, assim como fizemos em outra aula sobre o vocabulário da prostituição. Nunca ocorreu efetivamente uma aula sobre o assunto. Porém, Letizia, Jasmine, Natalie e eu assistimos juntas vários episódios de um reality show americano de drag queens, RuPaul's Drag Race, o que indicou um pouco sobre a semântica americana relacionada à questão trans.

Este reality show mobilizou uma controvérsia política e classificatória ao se defrontar com as disputas identitárias e consequentemente políticas do movimento "transgender" nos EUA. O movimento organizado de pessoas trans desse país reagiu contra atrações do programa que utilizavam terminologias consideradas pejorativas para 
descrever as pessoas que transitam entre as performances de gênero masculino e feminino neste contexto cultural, como "shemale" ou "tranny". Estes termos, segundo as portavozes desta militância, desumanizam as pessoas "trans".

Dentre as polêmicas suscitadas no decorrer do reality show estavam o uso do termo "shemale" em um dos jogos do programa que tinha como objetivo fazer as participantes diferenciar mulheres trans de mulheres cis. O programa retirou o quadro do ar, e a controvérsia denunciou uma questão de fundo político mobilizada pelo discurso deste segmento do movimento LGBT.

Conforme a percepção desta militância trans norte-americana ${ }^{16}$, o fato do programa de drag queens mostrar homens eventualmente vestindo-se de mulheres e usando uma linguagem pejorativa poderia deslegitimar as demandas por acesso à educação, saúde, trabalho e combate à transfobia frente ao público leigo no assunto, que não compreende os desafios diários de ser uma pessoa trans.

Cis, pessoa na qual o gênero corresponde ao sexo biológico, e trans, para quem não há correspondência entre o sexo biológico e performance de gênero, são categorias criadas por segmentos da militância transgênero que acreditam que termos "tranny" e "shemale", neste contexto de língua inglesa devem ser evitadas, pois fazem uma referência simbólica ao desvio e a marginalidade. O termo transexual também é considerado problemático, devendo ser substituído, afinal possui um sentido de doença mental e de patologia em ambas as línguas, por estar nos manuais médicos internacionais de doenças. O termo "cisgender" foi adicionado, em 2015, ao Oxford English Dictionary, como sendo a designação de uma pessoa cuja identidade pessoal corresponde ao sexo e ao gênero assignados ao nascer, demonstrando o amplo uso desta categoria, utilizada para expressar um vocabulário acerca das identidades de gênero.

Podemos afirmar que as classificações trans compõem um vocabulário complexo, uma vez que são produzidas dentro de contextos culturais específicos e possuem um caráter político, sendo mobilizadas de acordo com as circunstâncias e estratégicas dos atores, seja para oferecer uma feminilidade legítima ou pela atuação de certos segmentos militantes, reivindicando reconhecimento para suas demandas.

\footnotetext{
${ }^{16}$ ZACK FORD. The Quiet Clash between Transgender Women and Drag Queens. 25/06/2014. Disponível em: http://thinkprogress.org/lgbt/2014/06/25/3449462/drag-queens-trans-women/
} 
Contudo, antes de tratar do tema específico das classificações de identidade empregadas pelas mulheres trans, é necessário fazer um parênteses para descrever a peculiar semântica do cotidiano que, articulada a outros marcadores sociais de raça, classe, sexualidade e geração permitem expressões como "travecão" e a escolha peculiar dos nomes que foi apresentado na descrição da aula de inglês que inicio este capítulo.

Larissa Pelúcio (2007) observa que as travestis articulam na construção de si categorias ligadas a gênero, raça, classe social e geração. Neste mesmo sentido, Don Kulick (2008) afirma, em sua etnografia com travestis que se prostituem em Salvador/BA, que no caso brasileiro as pessoas trans se constroem tendo como base noções previamente estabelecidas em torno de valores morais, éticos e estéticos sobre gênero e sexualidade característicos de uma sociedade pós-escravista e assimétrica em termos de gênero.

Diante disto, podemos compreender a discussão na aula acerca dos diferentes nomes das travestis, e de Tatiane ter ironizado estes nomes ao afirmar que o seu "era mesmo nome de pobre". Os nomes são escolhidos mediante o "batismo" das colegas travestis ou pela "mãe" travesti que inicia a novata no processo de transformação corporal e vivência trans. Natalie, por exemplo, ganhou este nome ainda em sua terra natal pelas colegas, o mesmo aconteceu com Jasmine, nome dado pela semelhança com o de registro. Há uma anedota contada pelas meninas da casa que uma vez "Mãezinha" batizou uma menina fazendo referência a um doce de padaria que todas partilhavam à mesa que despertou uma inspiração súbita na matriarca nomeando a novata: "Eu te batizo de Carolina!". Portanto, estes nomes, escolhidos por outros ou por si própria são sempre consentidos e demarcam preferências de um coletivo.

A grafia do nome também é cuidadosamente pensada, seja por acrescentar Y ou dobrar letras como L. Como vimos na aula, houve discordâncias umas com as outras em relação às grafias do nome. $\mathrm{O}$ fato é que estes são "estrangeiros" na sua maioria, sendo que em alguns casos isto se constrói pela grafia, e assim, conferem um status em termos de classe para sua detentora, bem como em termos "raciais" - já que se associar com o inglês oferece um branqueamento para detentora deste nome. Letizia observou posteriormente que talvez naquela aula alguma das meninas tenham escrito e pensado publicamente sobre seus respectivos nomes pela primeira vez, pois até mesmo o reconhecimento do nome social nos atendimentos do serviço público é muito recente. 
O nome, nesta lógica, é uma forma de agência sobre si própria que as meninas trans possuem e que Tatiane não compartilhava por completo. A condição de "nome de pobre", ou ainda, de pertença a uma classe social já estava inerente a Tatiane, apesar de sua colocação ter sido também uma ironia quanto à estratégia de distinção adotada por suas colegas, porque esta nada significava em termos materiais, sendo apenas um status simbólico imaginado como tal. Porém, estes nomes saturados de Y ou L carregam uma certa noção de que sua feminilidade é hiperbólica, que transcende a uma "amapô"17 comum (mulher cis), portanto, são mulheres de um tipo especial, sempre muito bem vestidas, maquiadas, penteadas e esculpidas pelas mais diversas técnicas de transformação corporal.

Nesses embates, a distinção entre Natalie e Nataly, marcando estas fronteiras sociais e simbólicas com um Y, denota que para algumas destas mulheres trans os estrangeirismos nos nomes é uma forma de revelar suas origens justamente entre os mais pobres, produzindo o efeito contrário daquilo que se imaginava na construção de si como uma mulher em ascensão social. Natalie, nesta lógica, opera uma noção de classe específica a sua trajetória como Miss Transex, acumulando títulos nos concursos de beleza. Ela possui longos cabelos castanhos que terminam em mechas californianas douradas, se define como morena, nunca aparece sem maquiagem, com as unhas sempre bem feitas e decoradas, usando cotidianamente saltos altos que quase sempre são elaborados Peep Toe, veste-se à altura de uma modelo internacional antenada nas novas tendências da moda. Natalie reconhece, deste modo, que um nome saturado não lhe cairia bem, assim como a tradicional combinação de mini-top e mini-saia que se observa frequentemente nas ruas do Itatinga.

Outra razão para escolher um nome mais discreto estaria na consciência de que haveria nestes nomes repletos de Y, W ou L uma negativa das origens étnicas ou raciais. E, talvez, não de forma explícita o nome de Jasmine carregue este sentido, pois faz referência ao Amazonas, lugar de origem desta aluna, assim como o de Yasmin, uma outra travesti desta região. Yara, a travesti militante que descrevemos no capítulo anterior explicou que escolheu o seu nome como referência a figura mítica da sereia do folclore brasileiro.

Judith Butler (2002), ao analisar o documentário Paris is burning, conclui que as questões de gênero se articulam com raça e a classe social em determinadas realidades,

\footnotetext{
${ }^{17}$ Amapô significa mulher no bajubá, dialeto de origem Iorubá utilizado entre as travestis brasileiras.
} 
especialmente em contextos racistas e desiguais como o norte-americano, e que, portanto, o travestismo não significa necessariamente subversão. O documentário, produzido e dirigido por Jennie Livingston, retrata a cena de bailes de drag queens realizados no Harlem em Nova York, onde os participantes são "homens" afro-americanos ou latinos. Os bailes eram eventos nos quais os membros da comunidade gay se travestiam de várias maneiras, podendo expressar sua identidade, sejam as fantasias de ser um "superstar" ou uma "modelo de passarela". As festas constituíam-se em disputas nas quais os participantes competiam em uma variedade de categorias. Dentre as categorias, havia aquelas que faziam referência à cultura branca norte-americana, como o desfile de "executivos", estudante de universidades prestigiadas e de militar. Ou ainda, havia categorias que performatizavam a cultura heterossexual negra das ruas, como por exemplo, no desfile que se fazia passar por heterossexual. Por fim, existiam categorias cujo objetivo era se travestir de mulher, ocorrendo também neste caso o travestismo racial e de classe social. Um interessante aspecto dos bailes era a organização de seus membros em famílias ou "houses", que conferiam apoio mútuo e sobrenome aos seus membros.

No baile travesti, na análise de Butler, tem-se a produção de um sujeito que repete e parodia as normas que os tem degradado em termos de raça, classe e gênero, na qual sujeitos negros, homossexuais e pobres imitam o que imaginam que é ser branco e rico. No âmbito da festa ser autêntico durante a performance na passarela constitui o espaço da promessa fantasmática de um resgate da pobreza, da homofobia e do racismo (2002, p.191).

Butler (2002, p.199) conclui que "Paris em chamas" não documenta nem uma subversão eficaz, nem uma submissão dolorosa das normas hiperbólicas de gênero, mas uma coexistência instável entre ambas, através da apropriação das normas racistas e classistas da sociedade americana, bem como dos termos do parentesco heterossexual, por esses sujeitos negros e latinos.

Conforme Anne McClintock (2010, p.194), raça, classe e gênero podem se relacionar entre si, no entanto, não são equivalentes estruturais automáticos uns dos outros, pois a experiência vivida dos sujeitos são sempre complexas. De acordo com a autora, a mímica racial não é o mesmo do que travestismo de gênero, pois o travestismo de gênero é caracterizado pela valorização da ambiguidade, sendo o paradigma a "identidade como diferença". Se passar-se por outro grupo étnico ou racial, por sua vez, envolve mascarar a 
ambiguidade, sendo a "diferença como identidade".

O passar-se por racial não é o mesmo que o travestismo de gênero; o voguing (dança) negro não é o mesmo que brancos com as caras pintadas de preto, negros como menestréis não são o mesmo que drags lésbicas. (McClintock, 2010, p.110).

Além dos nomes é possível perceber no modo como se constrói um corpo ideal com base nessa simbologia que articula classe, raça e beleza. Certa vez, fazíamos um exercício de escrita de um anúncio de jornal oferecendo serviços sexuais. Eu me afirmei negra, a "black girl", o que incomodou Natalie que também participava da aula. De acordo com ela, eu não era negra, porque tinha a mesma "cor" que ela: "morena". Expliquei as diferenças entre Brasil e EUA sobre classificação racial, que nosso é racismo velado e que fomos estimuladas historicamente a adotar classificações de embranquecimento. Essas situações de autoatribuição são sempre muito complicadas no Brasil, nas aulas de Sociologia já havia incorporado este tipo de estratégia para criar uma reflexão sobre a temática, o que propositalmente provoca os alunos a desnaturalizar as classificações raciais, e no caso brasileiro, os da mestiçagem. Neste episódio da aula de inglês, seguindo a mesma lógica, continuei a indagar minha interlocutora naquele momento: "Mas, a Beyoncé não é da minha cor?".

"Bel, eu não sou negra, nem você é negra, pare de querer me convencer!" foi a resposta desta aluna trans "morena". Esta questão da identidade racial é complexa e perceber a raça muitas vezes nos discursos e práticas é complicado, mas ao mesmo tempo intuitivo, dado a sutileza que esta questão é arregimentada no dia a dia.

Evidentemente, nas escolhas dos nomes, modos de arrumar e tingir os cabelos quase sempre lisos e louros, as lentes de contato azuis e verdes que muitas possuem no pensionato, dentre outras coisas, faz-se uma referência a um padrão de beleza e status que está implícito à questão da raça. Assim, o modo como se constrói este feminino é atravessado por uma certa valorização dos atributos que marcariam a raça, tanto nas percepções do que seria beleza, quanto aqueles padrões imaginados como imperativos de sucesso no mercado do sexo e das interações amorosas. Nesta lógica, as diferentes posições de gênero, raça, classe, idade e sexualidade constituem "tensores libidinais que orientam sujeitos na busca por corpos e por prazeres", conforme aponta Laura Moutinho (2006, 
p.113).

Moutinho (2006) observa que há uma miríade de possibilidades de negociação na intersecção dos marcadores de raça, classe, gênero, sexualidade e geração nos encontros amorosos e sexuais ao descrever a trajetória de jovens negros homossexuais advindos dos subúrbios e favelas, que vivem em situação de extrema precariedade econômica e que percorrem o circuito LGBT do Rio de Janeiro. Assim, a autora descreve uma delicada cena na qual existe um "campo de possibilidades" maior para os jovens homossexuais negros mais escuros das favelas em termos de negociação em torno das relações amorosas interraciais e entre classes sociais distintas em comparação aos jovens heterossexuais e homossexuais ou ainda as travestis.

Para os jovens homossexuais negros essas possibilidades emergem especialmente através da prerrogativa do trânsito de seus respectivos locais de moradia para o circuito de sociabilidade homossexual. Sendo que as distinções de classe e o preconceito racial não são determinantes absolutos dos arranjos amorosos e sexuais, podendo derivar relacionamentos que - mesmo sendo marcadamente assimétricos - constituem trocas de diferentes perspectivas entre os agentes. Por exemplo, a existência de uma certa visão entre estrangeiros brancos sobre o desempenho sexual de negros oferece a estes jovens uma valorização de seus atributos nestas interações afetivas e sexuais distinto daquele que possuem em suas localidades de origem, em contrapartida, estes "gringos" oferecem possibilidades de circulação pelos espaços das classes médias e altas da cidade, algum tipo de ganho financeiro, ou ainda, o status relativo e as trocas culturais advindas deste tipo de relacionamento.

Portanto, as formas como são constituídos os arranjos amorosos e sexuais, bem como os atributos ditos de beleza que ofereceriam certa vantagem nestas interações, não seguem uma simples fórmula de que tudo aquilo que é branco, ou remete ao embranquecer, seria mais valorizado, mas podem se combinar em agenciamentos imprevistos nestas situações extremadas.

Yasmin, uma das meninas do pensionato, é um exemplo disso, por que constrói a si próprio através de uma identidade regional manauense, indígena, publicando fotos, utilizando roupas e acessórios que a distingue das demais justamente pela afirmação da diferença. Ela às vezes se autodescreve como uma "Tainá trans", com referência à menina 
indígena personagem do cinema brasileiro em filmes do mesmo nome. Ser diferente, seguindo a lógica de Yasmin, não implica desvalorização nas disputas amorosas, tampouco no mercado do sexo - inclusive é perceptível que ela obtém vantagens pecuniárias consideráveis nesta atividade.

Dentre as categorias êmicas das travestis que se prostituem transcritas por Pelúcio (2007, p.57), mas também observadas no campo, há uma articulação dos marcadores de gênero, raça, classe e geração que oferecem uma semântica daquilo que seria positivado ou desvalorizado no mercado do sexo e no modelo hegemônico de beleza. Dentre estas classificações temos a que são consideradas "tops" ou "européias", pois seriam as mais bonitas, que trabalham em filmes pornôs, com ensaios sensuais ocupando os pontos centrais e valorizados de prostituição. Por sua vez, as "ninfetas" são as travestis mais jovens, valorizadas por conta do vigor da idade. Os "gayzinhos" são aqueles que se transvestem mais não tiveram coragem de fazer intervenções estéticas radicais.

Pelúcio (2007, p.110) pontua que os códigos "ninfetinhas" e "travecões", seguindo esta lógica, são exemplo das tensões em relação ao ideal de feminilidade em termos de juventude. O "travecão", como exposto anteriormente, é uma forma muito pejorativa de se referir as pessoas, sendo um tipo de xingamento acionado nas discussões mais banais do cotidiano até nas brigas mais acaloradas. Este termo faz referência a uma estética corporal atribuída às travestis mais velhas que possuem uma aparência exagerada, fruto de transformações corporais em um tempo no qual as tecnologias do corpo não eram tão desenvolvidas. As "ninfetinhas" são valorizadas pela juventude e pela suposta naturalidade de suas transformações.

As "mariconas" também são alvo deste tipo de preconceito, pois também é uma categoria de geração atribuída aos clientes mais velhos, que incorpora normas homofóbicas ao descrever de forma negativa o fato de desejar ser passivo nas relações sexuais. Observei em algumas interações esta oposição as "Mariconas":

Perambulando pelo bairro antes de iniciar as aulas encontrei um grupo de travestis e mulheres que já conhecia há um tempo, sentei junto com elas na calçada para fumar um cigarro e "jogar conversa fora". Mirela desceu de um carro e juntou-se a nós. As amigas questionaram, "Como foi com a Maricona, Mona?" e ela responde, "Eu comi bicha, que nojo daquela velha!", provocando o riso das colegas. Logo passou um rapaz jovem entre nós e lançou olhares, e Mirela correu atrás dele para abordá-lo. 
Julia, a mais comediante entre nós gritou: "Essa bicha não perde tempo!". (Diário de Campo, Abril,2014).

Porém, a idade nem sempre é significada como algo pejorativo, afinal, como vimos ao longo deste texto, as travestis que, no contexto do bairro, são vistas como "mães" são em geral mais velhas que suas "filhas", e justamente por essa diferença de idade possuem uma autoridade legitimada pela experiência e capacidade de auxiliar na inserção das novatas nos códigos, práticas e técnicas na construção da travestilidade.

\section{Entre Trans, Travestis e Transexuais}

O problema das classificações de identidade foi uma das controvérsias que enfrentei logo no início da pesquisa, no momento da elaboração de meu projeto. Este era inicialmente destinado a estudar as "travestis", uma vez que diante de uma pesquisa preliminar, especialmente no discurso militante, estas tinham mais dificuldade que as "transexuais" dada sua condição específica em serem atendidas nas suas diversas demandas pelo sistema de saúde e jurídico. Portanto, partia-se do pressuposto que estas categorias tinham uma coerência e solidez, sendo "identificações" consolidadas.

No início do século XXI aparecem os chamados Estudos Queer, quem em geral têm como pressuposto a crítica à universalização e naturalização das categorias de "a mulher", "o homem", "Corpo", "Sexo", bem como as dualidades de sexo/gênero, masculino/feminino, ativo/passivo, homo/hétero e natureza/cultura, demonstrando as contradições destes conceitos e questionando os essencialismos das. Assim, ao analisar a bibliografia recente sobre esta temática das "identidades" trans, verifica-se o quanto estas são contextuais e políticas, podendo os indivíduos acioná-las de modo estratégico e situacional, como indicado pelos trabalhos de David Valentine (2007), Jorge Leite Jr. (2008) e Bruno Barbosa (2010).

David Valentine (2007), afirma que ocorreu uma transição classificatória nas últimas décadas para um modelo que prioriza a distinção entre gênero e sexualidade em detrimento daqueles que não se preocupam com este tipo de diferenciação. A criação do conceito de transgênero é o resultado desta distinção categórica entre gênero e sexualidade, advindo principalmente do campo intelectual e militante, e apropriado pelo Estado na 
construção de políticas públicas destinadas a este segmento. Porém, para alguns segmentos, principalmente os pertencentes às classes populares, esta categoria é exógena, não tendo sucesso para descrever a si próprio, bem como suas experiências de vida. $\mathrm{O}$ autor exemplifica esta problemática ao observar os encontros de um grupo de apoio para transgêneros, identificando que esta categoria fazia mais sentido para indivíduos que possuíam uma conexão com o Estado, tal como a orientadora do grupo em questão, do que para outros que se autodenominavam de inúmeras maneiras, tais como "gay" ou "butch" (Valentine, 2006).

Em "We're not about gender" Valentine (2002) pontua que a categoria "gay" foi progressivamente ao longo da história se deslocando do gênero para apenas descrever a orientação do desejo. No artigo, o autor questiona se é possível decidir qual experiência diz respeito ao gênero e qual corresponde à sexualidade em uma diversidade de identidades presentes no universo homossexual, porque as pessoas concretas utilizam-se de uma infinidade de categorias para descreverem a si próprio.

Jorge Leite Jr. (2008), ao pesquisar sobre estas categorias de identidade trans, verificou que estas não eram tão evidentes como se pensava no senso comum, pois tais classificações vão:

[...] do mais rígido em textos científicos ao mais intencionalmente flexível na cultura de massas passando pela complexa miscelânea de ideias, vivências e estratégias da experiência concreta e cotidiana de tais pessoas. (Leite Jr, 2008, p.13,14).

As classificações dos indivíduos que não se enquadram nos padrões de gênero normativos em termos da matriz heterossexual possuem uma história especifica, conectando-se aos contextos sociais e culturais de um dado período, o que não exclui a possibilidade de haver controvérsias e disputas discursivas em cada um destes momentos históricos. Leite Jr. (2008) ao realizar a uma genealogia, no sentido proposto por Foucault, das categorias referentes à ambiguidade sexual, identificou uma apropriação do sabe-poder médico discursivamente sobre estes corpos, na qual manuais internacionais de doenças associaram determinados indivíduos a "perversões sexuais", enquanto outros a "doenças mentais" que necessitam de tratamento, estabelecendo um capital linguístico aos distinguir estes sujeitos. 
Assim, as definições únicas sobre corpos e identidades sexuais, bem como os limites entre masculinidade e feminilidade nunca existiram como entidades prédiscursivas, variando conforme os grupos e os discursos (médicos, religiosos, políticos) mesmo no interior de uma época específica. Porém, essas concepções foram percebidas em seus respectivos contextos como naturais e vivenciadas como se assim o fossem.

Permanece ainda hoje no CID-10 de 1993, o termo "transexualismo" dentro da seção Transtornos da personalidade e do comportamento adulto, no itens seguintes:

F64. 0 - Transexualismo: Trata-se de um desejo de viver e ser aceito enquanto pessoa do sexo oposto. Este desejo se acompanha em geral de um sentimento de mal estar ou de inadaptação por referência a seu próprio sexo anatômico e do desejo de submeter-se a uma intervenção cirúrgica ou a um tratamento hormonal a fim de tornar seu corpo tão conforme quanto possível ao sexo desejado.

F64. 1 - Travestismo bivalente: Este termo designa o fato de usar vestimentas do sexo oposto durante uma parte de sua existência, de modo a satisfazer a experiência temporária de pertencer ao sexo oposto, mas sem desejo de alteração sexual mais permanente ou de uma transformação cirúrgica; a mudança de vestimenta não se acompanhada de excitação sexual. Transtorno de identidade sexual no adulto ou adolescente, tipo não-transexual. Exclui: travestismo fetichista (F65. 1). F64. 2 - Transtorno sexual na infância: Transtorno que usualmente primeiro se manifesta no início da infância (e sempre bem antes da puberdade), caracterizado por um persistente e intenso sofrimento com relação a pertencer a um dado sexo, junto com o desejo de ser (ou a insistência de que se é) do outro sexo. Há uma preocupação persistente com a roupa e as atividades do sexo oposto e repúdio do próprio sexo. $\mathrm{O}$ diagnóstico requer uma profunda perturbação de identidade sexual normal; não é suficiente que uma menina seja levada ou traquinas ou que o menino tenha uma atitude afeminada. Os transtornos da identidade sexual nos indivíduos púberes ou pré-púberes não devem ser classificados aqui, mas sob a rubrica F66. -. Exclui: Orientação sexual egodistônica (F66. 1) e Transtorno da maturação sexual (F66. 0).

F65 Transtornos da preferência sexual, que inclui: Parafilias

F65. 1 - Travestismo fetichista: Vestir roupas do sexo oposto, principalmente com o objetivo de obter excitação sexual e de criar a aparência de pessoa do sexo oposto. O travestismo fetichista se distingue do travestismo transexual pela sua associação clara com uma excitação sexual e pela necessidade de se remover as roupas uma vez que o orgasmo ocorra e haja declínio da excitação.

No DSM-IV, por sua vez, existia o capítulo Transtornos sexuais e da identidade de gênero que se dividia em Disfunções sexuais, neste estando as Parafilias, que incluem o Fetichismo transvéstico. Em outro item, o de Transtornos da identidade de gênero, havia 
os Transtornos da identidade de gênero em crianças e Transtornos da identidade de gênero em adolescentes ou adultos, além dos Transtornos da identidade de gênero sem outra especificação. Nesta versão do DSM ainda persistia a ideia de "bons" e os "maus" desviantes sexuais, os primeiros tendo um discurso mais condizente com os valores morais vigentes são classificados como portadores de transtornos, os segundos são vistos como pervertidos e desviantes (Leite, 2008).

O termo transexual possui, portanto, um capital linguístico dado sua associação com a psiquiatria e medicina, sendo que este capital pode dentro de certas circunstancias tornarse um capital social em contraposição ao estigma das travestis significadas nos termos da marginalidade. Por outro lado, dada a associação da transexualidade com a medicina e a psicologia é comum as que se autoidentificam como travestis acusarem as transexuais de loucura.

No caso brasileiro, por exemplo, o indivíduo pleiteante da cirurgia de transgenitalização deve passar por um acompanhamento clínico e terapêutico de uma equipe multidisciplinar por pelo menos dois anos, pelas regras do Conselho Federal de Medicina, e este pode não ser considerado possuidor de um "verdadeiro" ou legítimo desvio de identidade sexual. No entanto, é interessante relembrar a fala da travesti no evento sobre alteração de registro civil para pessoas trans que ocorreu no CEPROMM em 2014, por iniciativa da Defensoria Pública: "Tenho 10 anos de travesti, será que é mais fácil mudar de sexo?".

O mais recente DSM-V, de 2012, por sua vez, não utiliza mais o termo "Trastorno de identidade de gênero", retirando o sentido de doença mais literal que até então descrevia a condição transgênero, porém mantêm a "disforia de gênero", isto é, a angústia que sofre uma pessoa que não se encontra identificada com o seu sexo masculino ou feminino. $\mathrm{O}$ CID também pretende se adequar às mudanças no DSM em 2015.

Jorge Leite (2008) conclui que a performance de gênero esperada pelos discursos médicos analisados valoriza uma "feminilidade" específica, contida e sensível. Portanto, a luta por legitimidade social de travestis e transexuais está ligada ao reconhecimento do grau de humanidade dessas pessoas, associadas a transtornos e desvios pelos quais se demanda uma base estável para o sexo e performance de gênero. E, por fim, transexuais e travestis questionam as normas de gênero que definem o modo é pensado o sexo, bem como nosso 
conceito de humano, pois "quando nossos gêneros sentem-se dispostos a mudar, nossos corpos também mudam".

Tendo como finalidade estudar os usos sociais das categorias transexuais e travestis, Bruno Barbosa (2012) realizou uma etnografia no CRD (Centro de Referência da Diversidade), especialmente nas reuniões destinadas a discutir a condição trans, as chamadas Terças - Trans. O autor verificou que a autoidentificação com uma categoria ou outra dependia de elementos que ultrapassam a classificação médica, centrada na diferenciação de quem deseja ou não a cirurgia de transgenitalização, afinal há indivíduos que se denominam transexuais e que não desejam se "operar". Associar-se a uma categoria ou outra se conectava a classe, gênero, raça, bem como o posicionamento político das agentes.

Neste sentido, o autor observou que as transexuais operam na lógica do discurso da feminilidade verdadeira, sendo utilizados como signo dessa diferenciação o fato de desejar a cirurgia de transgenitalização, em concordância com o discurso médico, a afirmação de sofrimento, a necessidade da psicoterapia e a reiteração de uma heterossexualidade. A categoria transexual, ou a de transex, era preferida por algumas pessoas com a finalidade de se afastar do estigma de marginalidade da categoria travesti, associada à prostituição, possuindo "um capital higiênico" (Leite, 2008). A associação da categoria transexual e do discurso médico permite a atribuição de uma hierarquia de gênero entre travestis e transexuais. Como observou Barbosa (2012), os atributos acionados para afirmar a feminilidade verdadeira perpassam o gênero, classe, raça e idade, na qual as mais velhas, negras e pobres não se encaixam numa feminilidade vista como verdadeira em certos discursos, sendo associadas às travestis.

Por outro lado, era necessário ao discurso político-militante observado se associar à categoria travesti, defendendo-a como sujeito de direitos, acusando as que se autodenominavam de transexuais de doentes e de pouca consciência política quanto a sua posição social. Assim sendo, Barbosa (2012) afirma que ocorreram dois movimentos diferentes nos conflitos em torno das classificações nas Terças - Trans. De um lado, o afastamento do estigma travesti por meio do reforço de fronteiras pelas transexuais. Por outro lado, ocorreu o alargamento da estigmatização pelas travestis ao afirmar o pertencimento comum de transexuais e travestis como "homens", "viados" ou "loucas". 
Portanto, os significados e a adesão às categorias transexuais e travestis são contextuais, dependendo da posição social e das estratégias dos sujeitos.

Diante das problemáticas apresentadas acima, as categorias cis e trans atualmente têm ganhado espaço neste universo classificatório, especialmente entre a militância do chamado transfeminismo, considerando que as categorias existentes transmitem uma noção de doença psiquiátrica, como a de transexual, ou são estigmatizadas como a de travesti.

Ao conversar com Denise sobre quais meninas se disponibilizariam a ser entrevistadas, esta me indicou os nomes das transexuais, uma vez que já tinha conversado e convivido muito apenas com as travestis. Este episódio, dentre outros, deixou claro que dentro desta ambiência existe uma distinção clara entre aquelas que desejam se "operar", as transexuais, e as que não desejam, as travestis.

Porém, se autointitular travesti possui um significado especial, dada a conexão destas meninas com a militância através da convivência cotidiana com figuras politizadas como Yara e Denise. Esta convivência influencia um discurso do orgulho "travesti", como Natalie pontuou em uma das várias vezes que já conversamos sobre o assunto, afirmando que não tem problema nenhum com a nomenclatura travesti, mas não compreende muito bem a escolha de algumas colegas dos termos transexuais ou trans com a finalidade de afastar de si os preconceitos contra as travestis.

Para Yara, como observamos anteriormente, "Travesti é a própria bandeira", ou seja, para ela é necessário defender esta categoria em contraposição à substituição simbólica por transex, trans ou até mesmo transexual, pois muitas pessoas não se adequam aos discursos médicos relativas as estas nomenclaturas e muitas já morreram por serem tratadas de modo excludente ao longo da história justamente como "travestis".

Certa vez quando conversava com Yara sobre os processos judiciais de retificação de registro ela me confidenciou as dificuldades encontradas pelas trans que desejam a alteração do nome de registro, pois há uma percepção dos juízes de que era necessário um laudo médico indicando que a pessoa era transexual e que por isto estaria sofrendo psicologicamente, negando este direito as que se denominam de travestis.

As que se autoidentificam como transexuais, no entanto, também fazem parte do cotidiano do pensionato, dentre elas Maria e Michele. Maria faz tratamento psicológico para mudança de sexo, e é respeitada pelas colegas no cotidiano da casa. Michele, no 
entanto, é vítima em certos contextos de brincadeiras jocosas, sendo apelidada pelas colegas de "Michele-trans". Perguntei às meninas porque seria do apelido, e o que é ser “trans". Obtive como resposta que ela era muito trans, retruquei se todas não eram. Natalie, que acompanhava o debate, me respondeu que Michele era trans demais, e, a despeito das brincadeiras quanto ao apelido, este lhe foi dado porque na época em que ela chegou à residência pois já havia outra Michele na casa e era necessário distingui-las. No entanto, é sabido que Michele é vítima das brincadeiras por desejar a cirurgia, mas ainda não ter realizado transformações corporais como colocar silicone - o que para as colegas é uma contradição cômica, afinal ela não comporta o estereótipo de uma feminilidade legitima ou verdadeira.

Conforme Natalie, as “trans” são, em geral, muito femininas, ou seja, sentimentais, sofrendo demais, e assim, não conseguem superar esta condição permanente de sofrimento. São "loucas", no sentido que se vinculam a uma condição psiquiátrica também observado na fala de Yara citada acima. Natalie, portanto, dada sua posição de vivência em um ambiente militante pelas demandas de travestis e prostitutas, assume uma posição crítica às colegas que se autodenominam transexuais. Dentro desta perspectiva, podemos compreender por que Michele é vista como "trans demais", beirando a antipatia.

Jasmine, no entanto, acredita que estas distinções entre travestis e transexuais "não são de fato relevantes, afinal ela é uma mulher trans que não sabe se quer ou não operar, mas não tem problemas em ser vista como travesti”.

Natalie trouxe para o bairro várias amigas que se tornaram transexuais, e hoje em dia ganham "milhões" pelas ruas do Itatinga. Uma delas, em especial, afastou-se da amizade dela e das meninas da casa, pois segundo minha interlocutora estas geralmente depois de "operadas" costumam se distanciar porque acreditam que a simples proximidade com as travestis afetaria sua feminilidade, afinal se estas andarem com "homens" poderiam ser vistas como homem.

Outra razão para o distanciamento das transexuais operadas é a negativa do passado, de acordo com algumas travestis que também confidenciaram numa outra ocasião este afastamento das colegas já “operadas". Segundo elas, esta identidade passada é mantida em sigilo no bairro, pois as transexuais buscam imediatamente a "mudança de nome", já que, se verificado e publicizado, seriam lidas na chave da "masculinidade" e poderiam ser 
expulsas do bairro pelos "irmãos".

"Irmãos" é uma categoria nativa do "mundo do crime paulistano" que se refere aos indivíduos pertencentes a um grupo que organiza os encarcerados no sistema prisional paulista. Porém, esta entidade de organização de presos, e consequentemente das atividades criminosas nas periferias do Estado não se conforma como um grupo centralizado. Conforme Karina Biondi (2010), que realizou etnografia sobre a temática, este tipo de agrupamento é transcendente e imanente, no sentido de que são entidades que pairam sobre os indivíduos do sistema prisional, mas que dependem da ação de cada um para se concretizar. Todo preso potencialmente pode pertencer ao grupo desde que aceito como "irmão", sendo que antes disto pode ser "primo" - o aspirante a esta posição e a finalidade inicial da organização deste grupo era a de melhores condições no sistema prisional. As ações de cada um que pertence ao grupo dependem de decisões retiradas coletivamente, contudo é uma entidade descentralizada que se organiza localmente.

Moutinho $(2002,2006)$, ao estudar as sociabilidades afetivo-sexuais dos subúrbios e favelas do Rio de Janeiro, observou que, estando estas relações inseridas em territorialidades específicas, configuram possibilidades de arranjos e significados do desejo que se articulavam aos marcadores sociais da diferença. Por exemplo, era possível inferir um certo ethos viril cavalheiresco no subúrbio de Rio das Pedras, caracterizado como uma localidade em que a violência não era presente de um modo alarmante como em outras regiões. Nas localidades mais violentas, visualizava-se um ethos mais guerreiro na construção da masculinidade, especialmente nos grupos ligados ao tráfico de drogas. Portanto, a autora demonstra que há uma articulação entre a violência e tráfico de drogas e o idioma que se constrói em termos de gênero, raça e sexualidade de fundamental importância para a compreensão da dinâmica dos relacionamentos afetivo-sexuais interraciais entre parcerias gays e lésbicas dessas regiões. No caso do Itatinga é interessante como certa visão acerca das facções prisionais produz uma percepção que estas supostamente teriam uma função de regulação dos corpos, e assim, este imaginário é o resultado de uma articulação específica de território, violência e gênero.

No bairro, porém, esta faç̧ão das prisões paulistas foi me apresentada como misteriosa e em certa medida um tabu, aparecendo mais como um rumor. Nesta região, nunca conheci alguém que se autointitulasse membro da organização, mencionada apenas 
em algumas interações como uma entidade abstrata e genérica, constituindo talvez mais um dos vários signos de cruzamentos das margens atribuído no senso comum a esta região.

No entanto, o que nos interessa em relação a esta entidade percebida como abstrata é a visão deste grupo, imaginada como instância normatizadora, ao estabelecer dentre suas regras posições de gênero demarcadas, ou seja, controlar na medida do possível uma ordem moral coerente onde "homens" e "mulheres" possam ser identificadas claramente como tais, seja por questões econômicas ou por questões normativas.

Finalmente, a questão que as alunas levantaram na aula que iniciou este tópico foi o mote para que percorrêssemos uma miríade de classificações que dizem respeito às diferenças construídas atual e historicamente entre transexuais e travestis, bem como essas diferenças se articulam com os marcadores sociais da diferença em termos de raça, gênero e classe social. Diante disto, analisei o quanto as diferenciações entre travestis e transexuais são contextuais, e como isto opera no contexto específico do pensionato, do Jardim Itatinga, da prostituição e na atuação na militância LGBT e de profissionais do sexo. Por fim, podese afirmar que o bairro em si apresenta, por meio do imaginário dos indivíduos, uma regulação, seja por ordem moral ou econômica, em termos de coerência para estes corpos, o que não impede que as pessoas em si adotem múltiplas vivências e percepções de quem são elas dentro deste contexto. 


\section{CONCLUSÃO. A política das "locas" e a política das trocas}

No "Café Arte", um restaurante localizado em Barão Geraldo ao lado da Unicamp, encontro-me com um grupo de pesquisadoras que acabaram de participar da banca de qualificação de um amigo mestrando em Artes, na área de Arte/Educação. Lá estava eu entre três professoras pesquisadoras, que após algum tempo perguntaram: "E você Bel, o que pesquisa?”. Senti aquela ansiedade sempre presente neste tipo de questão e disparei como de costume a frase pronta e rápida que provavelmente muitos estudantes de pósgraduação possuem para descrever aquilo que estão fazendo. Expliquei o campo, não há como falar do que estou fazendo sem falar dele: "uma residência coletiva de travestis". Uma das professoras, que é do Instituto de Artes da Unicamp, não esperou nem que terminasse a frase e disse entusiasmada: "No Itatinga!". Ela nos relatou que um tempo atrás participara da banca de um estudante que fizera um trabalho de fotografia ${ }^{18}$ com travestis e prostitutas no Itatinga, mas o melhor, segundo ela, foi a festa após a defesa, porque pôde conhecer as interlocutoras do trabalho pessoalmente. Nesta festa conversou por mais de duas horas com uma travesti "Super militante. Como era o nome dela mesmo, você deve conhecer ela... Denise!".

O Itatinga tem essa contradição de ser um bairro distante, nas margens físicas e sociais da cidade, mas se conectar por meio de suas redes a circuitos outros, inclusive centrais dentro da dinâmica campineira, como a universidade. Afinal, de modo inesperado, no restaurante do bairro nobre, estávamos falando desta qualidade do Itatinga. Falávamos especialmente de Denise, que é uma interlocutora especial destas redes e reconhecida por isto, por essa capacidade de fazer política de reconhecimento e visibilidade para o grupo que representa.

Como já descrito no capítulo sobre a educação, Denise incentiva a participação das meninas nestes projetos acadêmicos e artísticos, seja convocando-as para uma palestra

\footnotetext{
${ }^{18} \mathrm{O}$ trabalho em questão talvez seja a dissertação de mestrado em Artes de Luiz Carlos Sollberger Jeolás, "VENDO (O) CORPO, VENDO (A) IMAGEM: a autorrepresentação fotográfica de mulheres e travestis profissionais do sexo do Jardim Itatinga, Campinas", de 2009. Denise participou como uma das interlocutoras da pesquisa que consistia de uma investigação de como as profissionais do sexo do Itatinga interpretavam o contexto social que as cercava por intermédio do uso da fotografia. Este artista realizou oficinas com as mulheres cis e travestis do bairro e estas elaboraram como produto final um conjunto de fotografias.
} 
jurídica sobre nome social ou as convidando para ser modelo e a inspiração de artistas. É uma troca de dádivas entre "objeto" de estudo (ou de arte, política, etc.) e pesquisador (artista, militante e assim por diante), com ganhos parcelares substanciais. Talvez ela tenha descoberto pela práxis, assim como outras militantes do Itatinga como Bethânia, uma fórmula interessante e até eficiente de conscientizar e mobilizar pessoas em torno das questões políticas que as cerca. Isto é fruto de historicidade do Itatinga, que envolve instituições e grupos que foram abordando este bairro ao longo do tempo em razão de sua peculiaridade, como igreja, universidade com pesquisadores e projetos de empreendedorismo social, agentes da política e do Estado e assim por diante.

Esta minha descrição pode parecer um pouco romântica, e em certa medida é mesmo fruto de um deslumbramento com o campo, mas é interessante perceber e valorizar esta capacidade de agência de um grupo social que esteve durante muito tempo e continua em certo sentido nas margens da cidadania como as travestis (ou trans, ou transexual, ou qualquer outra categoria que apareça neste sistema político classificatório extremamente dinâmico), pois ainda é vítima da violência transfóbica e da exclusão social em termos de escolaridade, qualidade de vida e saúde, atendimentos de demandas específicas como o reconhecimento do nome social e assim por diante. Demorei um pouco para descrever esta capacidade de ação, e daí que advém esta minha percepção de estar observando um contexto de margens, no sentido restrito do termo, pois estava contaminada com o discurso da militância, que é estrategicamente da carência.

Esta agência não está apenas na política das dádivas, que é aquela que Denise corporifica, mas também é a "das locas", como a passeata escandalosa no bom sentido empoderador que constrangeu a presença policial repressora nos eventos de Outubro de 2013 no Itatinga. Aliás, uma tática de ação é subsidiária da outra, pois a mesma revolta que motivou a marcha foi replicada de muitos modos pelas redes que o Itatinga possui, ou seja, por blogueiros militantes, estudantes universitários, defensores públicos, políticos profissionais e assim por diante.

Como observado no trabalho de pesquisa de Luiza Ferreira Lima (2015), que analisa os processos judiciais de troca de nomes de travestis e transexuais, ainda há pouco espaço para agência das requerentes deste tipo de processo diante de um judiciário que detém o poder de dizer, segundo concepções externas a estas e distorcidas, quem deve ter 
em seus documentos seu nome feminino.

Nesse debate, rememoro como vocabulário analítico os conceitos propostos por Félix Guattari (1996), segundo quem são molares os aspectos globais da sociedade, e moleculares aqueles que ocorrem no nível das relações sociais, das interações. No que diz respeito às relações globais com o Estado, podemos apontar a presença cada vez mais forte politicamente de setores conservadores que criam entraves à criação e implementação de políticas públicas direcionadas à população LGBT, como a aprovação da lei que criminaliza a homofobia - apesar de que na última década tenha ocorrido um progresso na inserção deste grupo como ator político, inclusive nas secretarias e ministérios.

Nesta mesma lógica, no caso da retificação de registro, no nível do molar, do Estado na sua faceta jurídica, a pseudociência, a religião, a classificação cultural e história das categorias de identidades, e tantas outras referências deslocadas acionadas pelos juízes conseguem predominar sobre o desejo de uma pessoa em ter respeito juridicamente a seu nome. Diante disto, já ouvi de algumas meninas do pensionato de Alice que não desejam a troca do nome em documentos, pois há muito trabalho ou não sentem necessidade, ou ainda, nos dizeres de Yara, não querem nenhum laudo que afirmem serem "loucas" (no mal sentido dos manuais de doenças).

Porém, justamente como resultado da construção destas redes de nível molecular da agência da militância de travestis/transexuais há uma ponte possível, seja por movimentos sociais ou acadêmicos, como o segmento de juízes progressistas que criam jurisprudência e esperanças de que este quadro de insegurança jurídica do nome social se transforme, como alguns magistrados apontados no trabalho de Ferreira Lima (2015).

Estes exemplos paradigmáticos de pontes estruturadas por redes da sociedade civil que se conectam ao Estado anunciam uma possibilidade de ação, constatando que não há, como evidenciado por estes contextos, um Estado monolítico e separado da sociedade afinal há uma percepção múltipla, inteligível ou não, para uma instituição que também é multifacetada. Portanto, há uma potencialidade de "revolução molecular" (Guattari, 1996, p.122), que diz respeito a um processo de mudança que parte do molecular ao molar, sendo esta uma atitude ética, analítica e política. No entanto, fica latente a questão da efíciência de atuação destas redes locais de militância da sociedade civil diante de uma ocupação crescente do Estado por setores conservadores marcados pelo discurso moral e religioso de 
políticos profissionais, que no legislativo impedem a criação de leis que combatam a homofobia e a transfobia e, no nível executivo, criam empecilhos à implementação de políticas públicas. Por exemplo, o projeto Escola sem Homofobia, elaborado pelo Governo Federal para o combate à homofobia nas instituições de ensino, a inclusão da promoção da igualdade de gênero e orientação sexual no Plano Nacional de Educação e nos respectivos Planos Municipais e Estaduais, entre outras iniciativas que foram barradas pelos legislativos em virtude da ampla influência das bancadas religiosas conservadoras.

Neste trabalho procurei realizar uma descrição do Itatinga e do pensionato de Alice e Juliana, coletividade trans que observei desde minha entrada em campo e da qual fazem parte as alunas do curso de inglês, que foi ministrado por mim e Letizia, minha companheira das andanças etnográficas por esta região. Descrevi neste texto a multiplicidade de pessoas e redes que compõem o Itatinga, que incluem, além das prostitutas e travestis locais, o circuito dos movimentos sociais e artísticos, o da produção acadêmica, das ONGs e políticos profissionais. Assim sendo, apresentei o Itatinga e suas moradoras como sendo parte das margens, pois, sendo um desvio da norma dominante, sofrem um processo de enquadramento e, enfim, de segregação, controle e vigilância, como observado por Guattari:

$\mathrm{Na}$ linguagem habitual, podemos dizer que as pessoas margens (marginais) são as vítimas de uma segregação e são cada vez mais controladas, vigiadas, assistidas na sociedade (ao menos nas desenvolvidas). É aquilo que se refere Foucault com a expressão vigiar e punir. (Ibidem, 1996, p.122).

Porém, novamente utilizando este vocabulário de Guattari (1996), o Itatinga e suas moradoras, especialmente militantes, seriam parte de uma margem que possui um devir minoritário, uma potencialidade de ação e transformação de suas condições. O devir, por sua vez, é rizomático, se conectando com outros segmentos sociais, como por exemplo, o devir mulher, o devir feminista, o devir negro e assim por diante. Portanto, são devires cujos efeitos não se restringem apenas ao grupo, influenciando outras dinâmicas sociais.

Em outras palavras: aqueles que se exprimem na faixa da marginalidade e da minoria colocam, sem dúvida, problemas que dizem respeito a esta faixa, mas que também dizem respeito ao conjunto da sociedade. (Guattari, 1996, p.123). 
A minoria é um devir minoritário e a marginalização é um processo mais passivo, de caráter sociológico (Ibidem, 1996, p.122). Ou seja, o devir possui agência, sendo a minoria uma luta por reconhecimento, enquanto que a marginalização é um processo que não parte dos agentes, mas incide sobre eles. Porém, é possível que ocorra um processo de troca dialética entre minoria e marginalização, segundo Guattari:

Podemos imaginar uma minoria que seja tratada como marginal ou um grupo marginal que queira ter a consistência subjetiva e $o$ reconhecimento de uma minoria, por exemplo. E aí teremos um conjunto dialético entre minoria e marginalidade. (1996, p.122).

Portanto, o Itatinga e suas moradoras são uma margem que ao longo do tempo foi se constituindo como minoria, fazendo parte de uma rede de movimentos sociais, acadêmicos e artísticos que estabelece uma maneira especifica de pensar e fazer-se na esfera pública do ponto de vista político. Deste modo, foi necessário considerar quais as posições que o Estado pode assumir nesta localidade a partir da perspectiva da observação da casa de travestis e transexuais, tendo como referências analíticas três problemáticas que analisei durante este tempo em campo: a saúde, a educação e o enfrentamento da violência.

$\mathrm{Na}$ questão da saúde pude observar por meio das falas dos agentes públicos preocupados com esta temática, que a distinção entre as categorias de transexuais e travestis ainda constitui um impedimento para efetivo acesso a técnicas de transformação corporal no sistema público de saúde, dado o entendimento normativo da busca pela coerência entre os corpos, dos profissionais da saúde envolvidos nestes processos.

No entanto, é perceptível no campo a eficiência de estratégias privadas para transformação dos corpos. A própria vivência na residência coletiva de travestis e o trabalho no bairro oferecem acesso ao capital econômico necessário para tanto, bem como compartilhamento nesta ambiência dos conhecimentos e técnicas do "fazer-se mulher". Contudo, na fala das usuárias, é perceptível há uma reivindicação por um sistema de saúde que as trate como indivíduos complexos, levando em conta todos os aspectos de sua vida, inclusive as dimensões da autoestima e bem-estar psicológico. Portanto, existe a demanda por um Estado que seja próximo de seus usuários e não uma instância impessoal e deslocada do cotidiano das pessoas.

A questão da violência, especialmente a perpetrada por agentes do Estado, foi uma 
experiência marcante neste ano de observação etnográfica no Jardim Itatinga, na qual foi possível observar uma faceta autoritária que o Estado pode assumir nesta localidade na ocasião da invasão do bairro pela polícia. Alguns meses após este episódio, um prédio destinado à prostituição em Niterói ${ }^{19}$, no Rio de Janeiro, também foi violentamente invadido pela polícia, o que foi denunciado pelo movimento de prostitutas locais, sendo perceptível que o estigma da profissão autoriza ou ainda legitima este tipo de intervenção violenta cometido por agentes de segurança pública. Porém, a fala "otimista" de Denise, de que é necessário reeducar os policias para o atendimento adequado para os cidadãos, sejam estes travestis ou prostitutas, demonstra que há uma percepção de que o Estado é uma instância de reivindicação possível de ser transformada pela ação dos movimentos sociais.

Finalmente, a educação foi um tema mobilizado pelo modo como fui inserida em campo, ou seja, por meio de curso de inglês, mas também pelas minhas experiências como professora de Educação Básica, ministrando a disciplina de sociologia na rede estadual de educação. Durante o andamento do curso de inglês foi possível identificar as dificuldades de aprendizado do grupo de alunas que não tiveram um acesso adequado à educação, bem como na minha própria experiência escolar em que testemunhei as dificuldades de uma aluna transexual em permanecer na escola. Assim, foi necessário investigar o papel da escola na trajetória das pessoas trans. Apesar da transfobia ainda presente no espaço escolar, este campo também se encontra em transformação, pois está ocorrendo a implementação de normas e políticas públicas que garantem o tratamento respeitoso e o acesso igualitário de alunas e alunos trans à educação.

Concluo, diante destas questões, que é interessante para descrever o contexto no qual se insere esta pesquisa apresentar o Estado na sua multiplicidade, pois apesar deste aparecer em certas conjunturas e por meio de determinados agentes como autoritário para a população em questão, ele também é reconhecido como instância de reivindicação de direitos e acaba também adquirindo formatos específicos por meio da atuação destes sujeitos políticos locais.

\footnotetext{
${ }^{19}$ Ver http://www.agenciaaids.com.br/noticias/interna.php?id=22311.
} 


\section{Referências}

AGIER, Michel. Antropologia da cidade. Lugares, situações, movimentos. São Paulo, 2011.

AGUIÃO, Sílvia. Fazer-se no" Estado": uma etnografia sobre o processo de constituição dos" LGBT" como sujeitos de direitos no Brasil contemporâneo. 2014. Tese de Doutorado. Tese de Doutorado, Campinas, PPGCS/Unicamp.

BIONDI, Karina. Junto e misturado: uma etnografia do PCC. São Paulo: Editora Terceiro Nome, 2010.

ABRAMOVAY, Miriam; CASTRO, Mary Garcia; SILVA, Lorena Bernadete Da. Juventudes e sexualidade. Brasília: Edições UNESCO Brasil, 2004.

BAHIA, Karolina; LUIZARI, Larissa e FARIA Nara. 2003. Zona de prazeres: o confinamento da prostituição no Jardim Itatinga. Campinas, 2003. Disponível em: http://zonadeprazeres.blogspot.com.br/2009/03/notas-das-autoras.html

BARBOSA, Bruno Cesar. Nomes e diferenças, uma etnografia das categorias travesti e transexual. Dissertação de mestrado. São Paulo: Universidade de São Paulo, 2010.

BUTLER, Judith. Problemas de Gênero: feminismo e subversão da identidade. Rio de Janeiro: Civilização Brasileira. $2^{\mathrm{a}}$ edição, 2008.

BUTLER, Judith. Cuerpos que importan. Buenos Aires, Barcelona, México: Paidós, 2002.

BUTLER, Judith. El grito de Antígona. Barcelona: El Rourc Editorial, 2001.

CLIFFORD, James. A experiência etnográfica: antropologia e literatura no século XX. Rio de Janeiro: Editora UFRJ, 1998.

DANILIAUSKAS, Marcelo. Relações de gênero, diversidade sexual e políticas públicas de educação: uma análise do Programa Brasil Sem Homofobia. 2011. Tese de Doutorado. Universidade de São Paulo.

DAGNINO, Evelina. "Culture, Citizenship and Democracy: Changing Discourses and Practices of the Latin American Left". In: Sonia Alvarez, Evelina Dagnino y Arturo Escobar (eds.), Culture of Politics/Politics of Culture: Revisioning Latin American social movements. Boulder, CO: Westview Press, 1998.

DAS, Veena e POOLE, Deborah. El estado y sus márgenes: Etnografías 
comparadas.Buenos Aires: Cuadernos de antropologia social, 2008. p.19-52.

ELIAS, Norbert. "Processos de formação do Estado e construção de nações". In: Escritos \& Ensaios 1 - Estado, Processo, Opinião Pública. Rio de Janeiro: Jorge Zahar, 2006.

FACCHINI, Regina. Sopa de letrinhas? Movimento homossexual e produção de Identidades coletivas nos anos 90. Rio de Janeiro: Garamond - Seção Garamond Universitária, 2005.

FACCHINI, Regina; FRANÇA, Isadora Lins; VENTURI, Gustavo. Sexualidade, cidadania e homofobia: pesquisa 10 a. parada do orgulho GLBT de São Paulo-2006. APOGLBT, 2007.

FELDMAN, Sarah. Segregações Espaciais Urbanas: a Territorialização da Prostituição Feminina em São Paulo. Tese (Mestrado em Arquitetura e Urbanismo) FAU/USP, São Paulo, 1989.

FERREIRA LIMA, Luiza. Julgando identidades, prescrevendo diagnósticos: o papel do saber médico em decisões judiciais sobre retificação de registro civil de transexuais. In: "A verdade produzida nos autos": uma análise de decisões judiciais sobre retificação de registro civil transexuais em tribunais brasileiros. Dissertação de Mestrado. São Paulo, PPGAS/USP, 2015.

FOUCAULT, Michel; MISKOWIEC, Jay. Of other spaces. Diacritics, p. 22-27, 1986.

FOUCAULT, Michel. Aula de 17 de março de 1976. In: Em defesa da sociedade. São Paulo :Martins Fontes, 2002.

FOUCAULT, Michel. História da sexualidade I: a vontade de saber. São Paulo: Graal, 2001.

FOUCAULT, Michel. Herculine Barbin: o diário de um hermafrodita. Rio de Janeiro: F. Alves, 1982.

LOPES LOURO, Guacira. Pedagogias da sexualidade.In: O corpo educado :Pedagogias da sexualidade. Belo Horizonte: Autêntica, 2001.

KULICK, Don. Travesty violence and scandals. Rio de Janeiro: CLAM/UERJ, 2008.

HELENE, Diana. A invenção do Jardim Itatinga, o zoneamento urbano da prostituição. 
$28^{\text {a }}$. Reunião Brasileira de Antropologia. São Paulo, 2012.

INGOLD, Tim et al. The concept of society is theoretically obsolete (debate). In: INGOLD, Tim (org.). Keys debates in anthropology. London e New York: Routledge, 2005.

JEOLÁS, Luiz Carlos Sollberger. Vendo (o) corpo, vendo (a) imagem: a autorrepresentação fotográfica de mulheres e travestis profissionais do sexo do Jardim Itatinga, Campinas. / Luiz Carlos Sollberger Jeolás. - Campinas, SP: [s.n.], 2009.

LEITE JUNIOR, Jorge. Nossos corpos também mudam. Sexo, gênero, e a invenção das categorias "travesti" e "transexual" no discurso científico. São Paulo: Tese de doutorado em Ciências Sociais. São Paulo: PUC-SP, 2008.

McCLINTOCK, Anne. Couro imperial. Raça, gênero e sexualidade no embate colonial. Campinas, Ed. da Unicamp, 2010.

MACKINNON, Catharine A. Feminism, Marxism, method, and the state: An agenda for theory. Signs, p. 515-544, 1982.

MACKINNON, Catharine A. Toward a feminist theory of the state. Harvard University Press, 1989.

MAGNANI, J. E TORRES, Lilian (org.). Na metrópole - textos de antropologia urbana. São Paulo: Edusp, 1996.

MARCEL, MAUSS. Ensaio sobre a dádiva: formas e razão da troca nas sociedades arcaicas. In: . Sociologia e Antropologia. São Paulo: Cosac \& Naify, 2003.

MAZZARIOL, Regina Maria. Mal necessário: Ensaio sobre o confinamento da prostituição na cidade de Campinas. Dissertação de mestrado em Antropologia Social. IFCH/UNICAMP, Campinas, 1977.

MAZZON, José Afonso. Preconceito e discriminação no ambiente escolar. São Paulo: Fundação Instituto de Pesquisas Econômicas-USP e INEP, 2009.

MEC. Caderno Escola Sem Homofobia, 2012.

MISKOLCI, Richard; PELÚCIO, Larissa. Fora do sujeito e fora do lugar: reflexões sobre performatividade a partir de uma etnografia entre travestis. Revista Gênero, v. 7, n. 2, 2007.

MOUTINHO, Laura. Considerações sobre violência, gênero e cor em Rio das Pedras. In: Burgos, Marcelo (Org). A utopia da comunidade: Rio das Pedras, uma favela 
carioca. Rio de Janeiro: Editora Puc-Rio, 2002.p.273-297.

MOUTINHO, Laura. Negociando com a adversidade: reflexões sobre "raça", (homos) sexualidade e desigualdade social no Rio de Janeiro. Revista Estudos Feministas, v. 14, n. 1, p. 103-116, 2006.

NEWTON, Esther. Mother Camp: Female impersonators in America. University of Chicago Press, 1972.

OCHOA, Márcia. Ciudadanía Perversa: divas, marginación, y participación en la "localización" In: MATO, Daniel. (Ed.) Políticas de Ciudadanía y Sociedad Civil em Tiempos de Globalización. Caracas, FACES - Universidad Central de Venezuela, 2008, pp.239-256.

PATRIARCA, Letizia. Donas de casa de prostituição, mulheres no negócio do sexo. Projeto de mestrado. São Paulo: PPGAS/ USP, 2013.

PATRIARCA, Letizia. "As corajosas": etnografando experiências travestis na prostituição. Dissertação de mestrado. São Paulo: PPGAS/USP, 2015.

PELÚCIO, Larissa. "Nos nervos, na carne, na pele": uma etnografia sobre prostituição travesti e modelo preventivo de AIDS. São Carlos: UFSCAR, 2007.

PELÚCIO, Larissa. Na noite nem todos os gatos são pardos: notas sobre a prostituição travesti. Cadernos Pagu. Campinas, n. 25, 2005.

REIDEL, Mariana. A pedagogia do salto alto: histórias de professoras transexuais e travestis na educação brasileira. Dissertação de mestrado. Porto Alegre: Programa de Pós-Graduação em Educação/ UFRS, 2014.

ROLNIK, Suely; GUATTARI, Félix. Micropolítica: cartografias do desejo. Petrópolis, Rio de Janeiro: Vozes, 1996.

RUBIN, Gayle. Thinking sex: Notes for a radical theory of the politics of sexuality. Culture, society and sexuality: A reader, p. 143-179, 1999.

RUBIN, Gayle. "Pensando sobre Sexo: Notas para uma teoria radical da política da sexualidade". Cadernos Pagu, Campinas: Núcleo de Estudos de Gênero Pagu UNICAMP, n.21,2003.

SANTOS, Paulo Reis. Entre necas, peitos e picumãs: subjetividade e construção identidária das travestis do Jardim Itatinga. Dissertação (Mestrado em Educação) - 
Faculdade de Educação. Campinas: Universidade Estadual de Campinas, 2008.

SILVA, Hélio R. Travesti - A invenção do Feminino. Rio de Janeiro: Relute Domará/ ISER, 1993.

STRATHERN, M. O gênero da dádiva: problemas com as mulheres e problemas com a sociedade na Melanésia. Tradução de André Villalobos. Campinas, SP: Editora da Unicamp, 2006.

STRATHERN, Marilyn. O efeito etnográfico. O efeito etnográfico e outros ensaios. São Paulo; Cosac Naify; 2014. p. 345-405,

TURNER, Victor. O processo ritual. Petrópolis: Vozes, 1974.

TURNER, Victor. The Anthropology of performance. New York: PAJ Publications, 1987.

TURNER, Victor. Dramas, campos e metáforas: ação simbólica na sociedade humana. Rio de Janeiro: Ed.UFF, 2008.

UNESCO. O perfil dos professores brasileiros: o que fazem o que pensam o que almejam. São Paulo: Moderna, 2004.

VALENTINE, David. We're not about gender": The uses of "transgender.". Out in theory: The emergence of lesbian and gay anthropology. University of Illinois Press, 2002.

VALETINE, David. "I Went to Bed With My Own Kind Once: The Erasure of Desire in the Name of Identity. In: Stryker, Susan, and Stephen Whittle, Eds. In: The transgender studies reader. Taylor \& Francis, 2006.

VALENTINE, David. Imagining transgender: An ethnography of a category. Duke University Press, 2007.

VENTURI, Gustavo et al. Diversidade Sexual e Homofobia no Brasil-Intolerância e Respeito às Diferenças Sexuais. São Paulo: Fundação Perseu Abramo, Fundação Rosa Luxemburg Stiffung, 2009.

WESTON, Kath. Families We Choose: Lesbians, Gays, Kinship. Columbia University Press, 1997.

WEEKS, Introduction. In: Coming out: homosexual politics in Britain, from the nineteenth century to the present. London: Quartet Books, 1977. 
ZACK FORD. The Quiet Clash between Transgender Women and Drag Queens. 25/06/2014. http://thinkprogress.org/lgbt/2014/06/25/3449462/drag-queens-transwomen/ 